Historic, Archive Document

Do not assume content reflects current scientific knowledge, policies, or practices. 

3 gragressibe
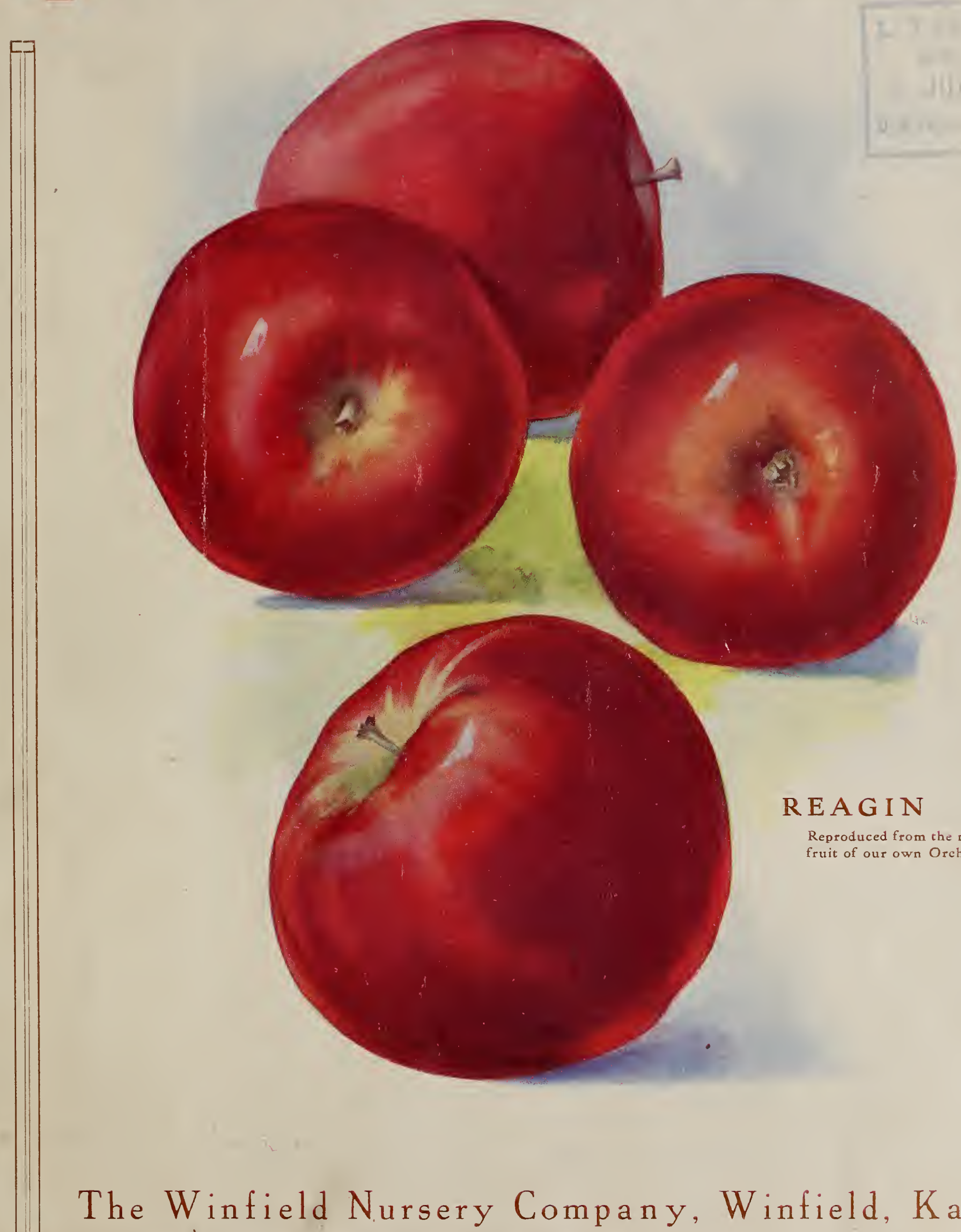

Reproduced from the natural fruit of our own Orchard.

The Winfield Nursery Company, Winfield, Kansas W! 



\section{Arouressibe 舀articulture}

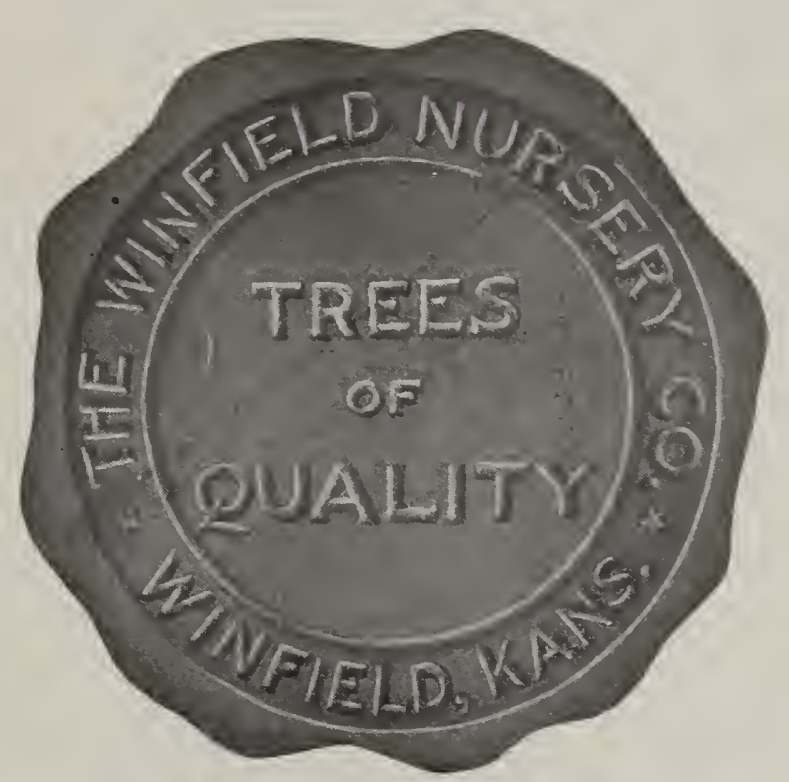

\section{THE WINFIELD NURSERY COMPANY
J. MONCRIEF, President
C.
(ᄄ. \\ (Incorporated) \\ R. I. LEMON, Sec'y \& Treas.}

Main Nursery Offices and Storage Buildings, Winfield, Kansas Branch Plants: Wellington, Kan., Hackney, Kan., Rossville, Kan. and Huntsville, Ala. 


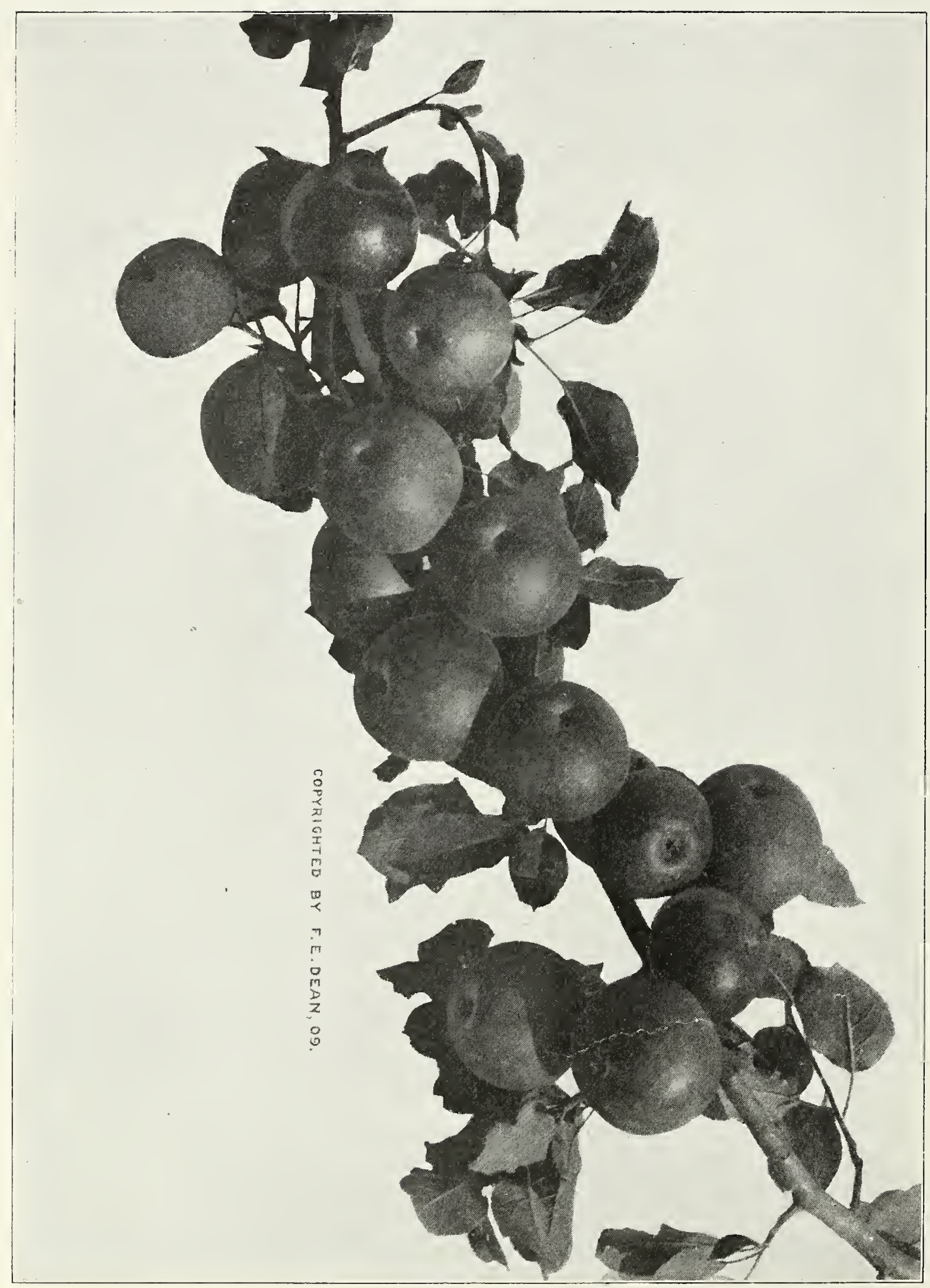

Branch of Stayman Winesap in orchard of A. B. Stoddard, Clifton, Colorado. All scions from these trees reserved for The Winfield Nursery Trees of Quality 


\section{“Every Year Grow Better Stock"}

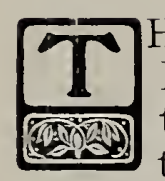
HE above caption is the slogan of The Winfield Nursery Company. We have long since gotten out of the old rut of trying to grow fruit trees and small fruits on the cheap plan. We improve the quality, color and size of fruit produced by our trees by "breeding up." Progressive Horticulture is indeed our standard in the propagation of Trees of Quality. By a thorough research and constant study of Nature's laws relative to bud variation, heredity and environment, we are determined to progress every year.

\section{"NEW FRUIT" CRAZE}

Many planters are becoming afflicted with a mania or disease which should be diagnosed as "NewFrui-tis.' This very extraordinary disease begets a desire on the part of the planter to grow new varieties-at great expense-and a loss of from four to ten years time.

New varieties of fruits should never be planted in large quantities until they have passed through the experimental stage. Common Sense is sufficient reason for this course. The great work of Luther Burbank should convince every planter of the fact that only an occasional seedling out of many thousands is worthy of propagation. New seedling varieties, even of merit, usually require years of time to breed out course fiber, thick skin and other undesirable qualities that are inherent.

Progressive Horticulture means that we are maintaining what we now have in quality and constantly improving the same. We recognize new fruits only after their merits have been thoroughly tried and tested. By following this course, we do not waste years of valuable time as well as large sums of money on new fruits which prove profitable for the introducer only. So great has been the loss of both time and money in the introduction of such fruits as the
Mariana plum, Blackman, Gold plum and numerous other varieties, that we recommend a new fruit only after a thorough trial.

\section{LIVE STOCK IMPROVEMENT}

The marked improvement that has been made in the development of Live Stock during the past few years has not been made by the introduction of a multitude of new breeds every year but rather by the selection of the best individuals for breeders.

\section{NURSERY STOCK IMPROVEMENT}

The laws of live stock improvement apply in the development of nursery stock. In other words, by individual selection, we must improve the Kings and Queens of Quality that we now have and stop this pernicious practice of inbreeding generation after generation. Some nurserymen admit cutting peach buds from nursery row for so many years that they do not know when they were ever renewed. One nurseryman told us that his buds were cut from the same varieties that his uncle had started before him. Others have told us frankly that they had never seen any fruit from the varieties they are growing and that they would not recognize the fruit if they were to see it. This "variety" of nurserymen call us cranks and declare that our "breeding up" idea is merely a hobby. Under the circumstances we prefer the honor of being cranks.

Each planter should know that in each future year he will get a little better Winesap apple. bred to improve the size and insure younger bearing; Jonathans grown only from vigorous trees that show their vitality by their fruit. The nurseryman who follows this line and insists upon getting the very hardiest stocks for base or foundation in grafting and budding is lifting the wheel out of the old rut. This is Progressive Horticulture. 


\section{The Winfield Nursery Quality Trees \\ Produced by Progressive Horticulture}

"Trees of Quality" has been a synonym for The Winfield Nursery Co. in every nook of the world where our trees have gone. The fact that dependable varieties can always be secured has been the great factor in the rapid development of the Company's business. Every year business is practically double the business of the previous year. Where we formerly

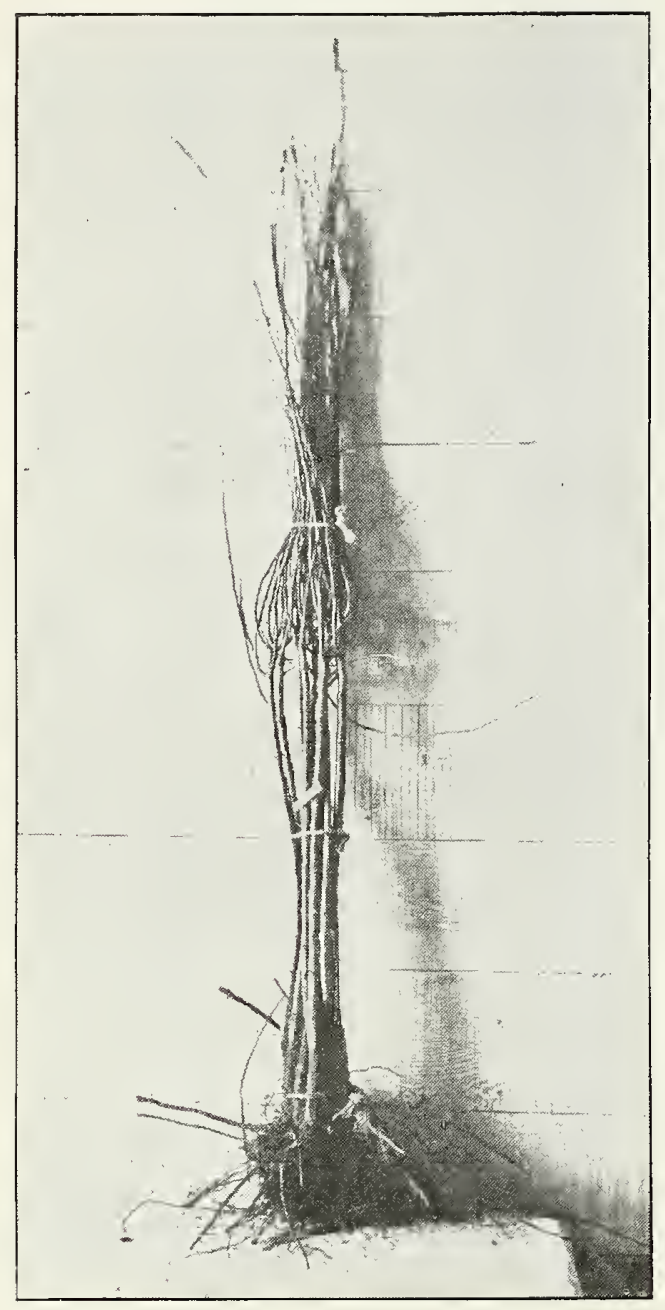
Average two year Apple Trees grown
by cheap method of scion and graft.

shipped in small local lots we now ship in carload lots and some instances lots approaching a train load in quantity.

We have kept pace with this rapidly increasing business by constantly adding and adapting new ideas and modern facilities. In order to get and utilize a variety of soils we have established a regular system of Branch Nursery Plants in different sections of the country. Overseeing and studying these various plants we have a corps of nursery specialists. By this system of constant observation and study we acquired a thorough knowledge of planting and planning orchards that is invaluable to planters of every class.

\section{MECHANICAL FACILITIES}

Storage Building and Fumigation House--Our large storage building eighty feet square on the inside and sixteen feet high, is erected with three dead air spaces in the walls, three thicknesses of insulated felt, two of lumber and the brick and stone wall. The roof, doors, and all other parts of this building conform strictly to the most improved method for a modern storage building. The main storage room is cut off from the packing room, which insures absolutely no

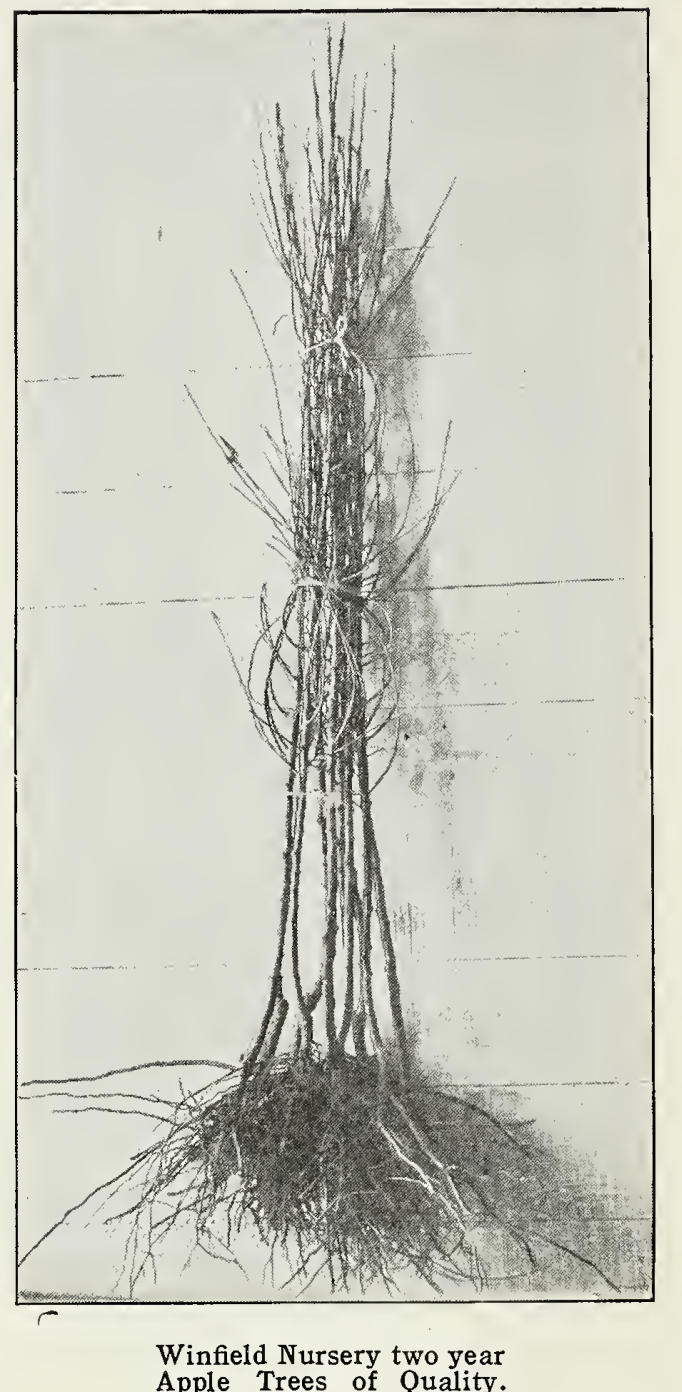

exposure of the tender fibrous roots of stock while being packed. Thousands of dollars have been spent on these packing facilities alone in order to handle nursery stock by the most approved methods and the increase in our business will demand another building this summer. The fumigation room was planned after consulting the best buildings of this kind in all parts of the United States and according to the approved plans of several of our leading state horticulture inspectors. This building is an air tight room with slat bottom whereby the chemicals can be placed underneath the slats so as to thoroughly fumigate the nursery stock. While this section of the country is located in a district far removed from orchard pests of any kind, no block of stock here ever having been condemned by an inspector since we have been in business, we take the precaution of fumigating all of the young stock and seed which we-plant and trees which would be liable to have any small insect eggs 


\section{Progressive Horticulture}

not visible to the eye are fumigated before being shipped out to the trade, in order to insure our customers clean healthy nursery stock.

\section{OUR RESPONSIBILITY}

Over one third million dollars in our combined companies invested in Real Estate, $\$ 250,000.00$ of this is invested in commercial orchards alone.

\section{HOLDINGS}

The Winfield Nursery Co., Winfield, Kans. Location of home nurseries, general offices, storage and packing buildings.

Wellington Branch Plant. Including large stock of Apple, Peach and Forestry seedlings. Over four million Pure Speciosa Catalpa Seedlings were grown at this plant in 1909.

Hackney Branch Plant. Ideal, sandy-loam land here with fine clay subsoil; devoted exclusively to Fruit Trees of Quality. Over one million fruit trees in this plant in 1910.

Huntsville, Alabama. Especially adapted to Pear, Cherry and Peach. nearly one hundred thousand Hottes Elberta alone in this plant for 1910.

Rossville, Kansas. A plant devoted almost exclusively to stocks for propagation.

The Palisade Fruit \& Land Co., Palisade, Colo. In this magnificent fruit valley we hold 120 acres of three year-old Elberta Peach orchard now valued at $\$ 1100$ per acre. Twenty acres bearing apple orchard planted to Reagan, Stayman Winesap and other choice varieties. Value, $\$ 1500$ per acre. These lands in the most famous irrigated fruit belt in the world, "Grand Valley" furnish us over fifteen thousand choice Elberta trees from which to secure our buds.

The Green River Fruit \& Land Co., Green River, Utah. Three hundred acres planted here on best irrigated fruit land to Bartlett, Buerre De Anjou, Keiffer and Garber pear; Elberta, Champion, and Salway Peach and best varieties of Apple, heaviest bulk. This fruit land alone was appraised at $\$ 129,000$ in the fall of 1909 . It gives us over 40,000 Quality Trees from which to select buds.

The Moncrief-Cook Co., Lawton, Okla. Abstract and loan business and extensive park work in our addi-

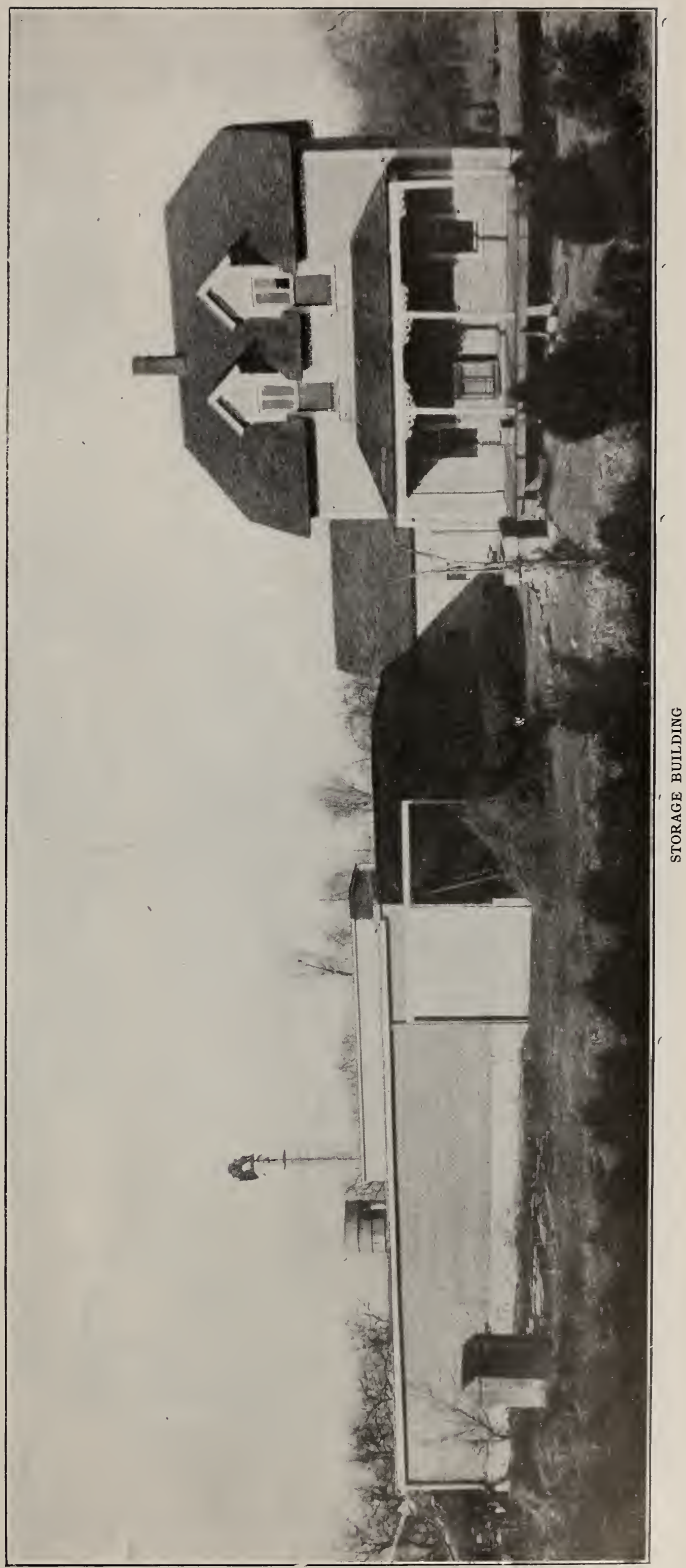


tion to the city of Lawton. This Company with its branch office at Frederick, Okla., knows soil and topography as does no other firm in Oklahoma. Field and topographical notes have been carefully written by their corps of field men during the past nine years on over 10,000 quarter sections of land in Oklahoma.

\section{PUBLICATIONS}

By The Winfield Nursery Co.:

"Trees of Quality: What Others Say about Them."

"Commercial Fruit Growing Bulletin."

"Planters Fruit Guide."

"Progressive Horticulture," a combination of facts relative to horticulture progress, and description of varieties.

"How to Detect Genuine Speciosa Catalpa Seed from the Common of Worthless Seed;" a clear, forcible article by Joseph Moncrief.

"Bulletin of Information on The Future Timber
Supply and Speciosa Catalpa,"an illustrated booklet. All of the above publications are mailed free of charge.

\section{By The Moncrief-Cook Co.}

Handsome Illustrated Booklet describing the splendid city of Lawton, Okla., and the great opportunities there for profitable investment. Also describes the country giving full and complete information relative to the great state of Oklahoma.

By The Palisade Fruit \& Land Co.

Illustrated Booklet with over 25 beautiful views of orchards and homes. Also a large array of facts relative to large incomes derived from all kinds of fruits as well as a description of the great irrigation Fruit Belt of the Grand Valley. Mailed free.

By The Green River Fruit \& Land Co.

"Advantages of the Irrigated Fruit Valley." Mailed free.

\section{Special Information}

Write and tell us the number of acres you think of planting and number desired of each class of fruit;or merely give number of acres you wish to plant and we will draw for you, entirely free, complete plans for planting to greatest advantage. Plans and general information which we give you entirely free has cost us thousands of dollars actual cash besides much valuable time. In order to benefit our own fruit orchards in the irrigation districts we have spared neither time nor expense in thorough investigation on all lines that will tend to aid us in the production of the best.

Here are a few of the subjects that we have studied carefully: "Kinds of Soil," "Best Quality Apples," "Varieties Profitable for Local or State Markets," "Varieties Profitable for Eastern Markets," "Varieties Profitable for Fancy Export Market;" In this the Reagan leads. "Corporation Plans of Fruit Growers' Associations," "Pruning," "Spraying," and a hundred other subjects information upon which will be furnished to you entirely free.

\section{SHIPPING FACILITIES}

We have A. T. \& S. F., Southern Kansas, Walnut Valley, Frisco and Missouri Pacific railways. Twenty five or thirty trains pass through in all directions daily. Also Wells Fargo, Pacific, and United States Express Companies. No city in the west has better shipping facilities.

\section{NOTICE TO CUSTOMERS}

In Ordering by Mail-State plainly your post office also point to which you want stock shipped, or still better write to office, when regular mail order blank will be sent you. Orders from unknown parties should be accompanied by cash or satistactory references.

Time of Shipment--This depends very much upon the season of the year. Trees can not be delivered in the fall until after ripened by the frost. All orders accepted, as to time of shipment will be subject to our discretion, as customers interests and ours are mutual in regard to the successful planting of trees. 


\section{Winfield Nursery Trees of Quality \\ In the Making}

French Crab Seedlings. A plant grown exclusively for us every year on best of ground selected especially for growing hardy well-rooted seed-

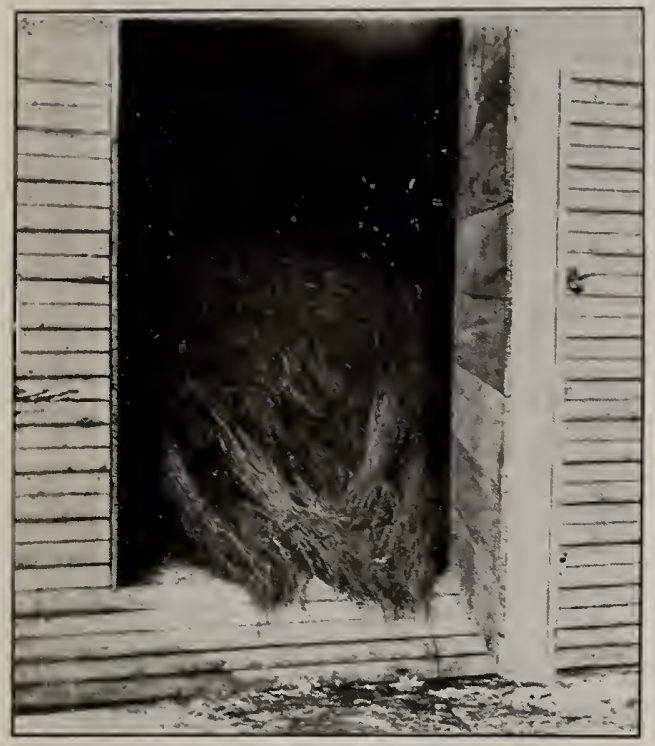
lings clear of any disease. The seed are a select import from wild hardy crabs of France.

The cut to the left shows our thorough process of fumigating seedlings and scions. This is done in order to destroy any and all insects that may be passed by even the glass of the inspector.

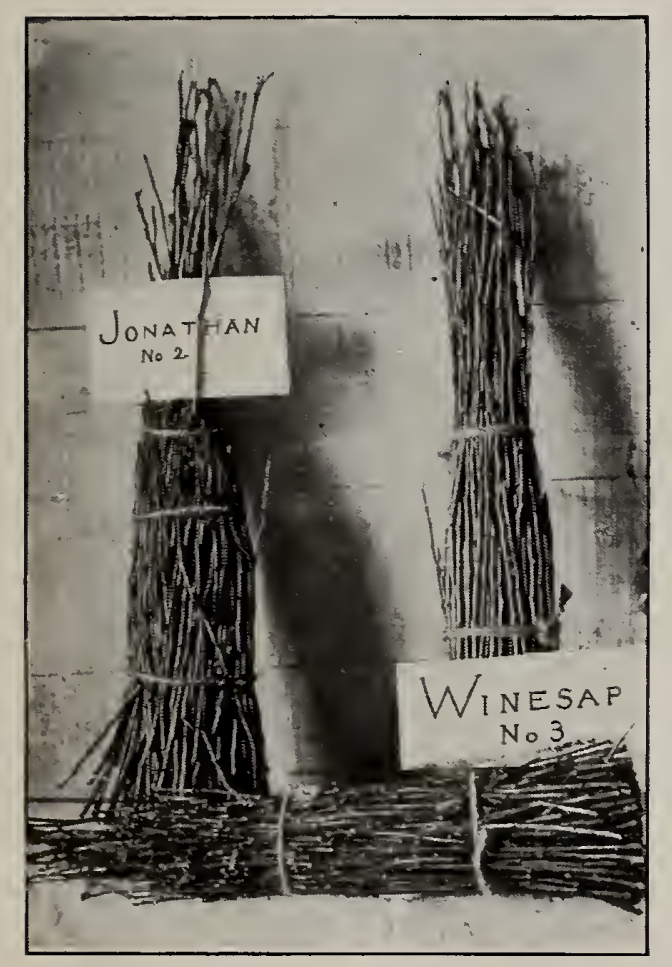

Scions of Selection. -The accompanying illustration displays choice scions selected from bearing orchards. By use of a score sheet hardy, fru itf $\mathrm{l} 1$ trees of merit are marked for scions. This method insures vigorous trees of vitality and superb root systems in nursery rows. It also assures the planter big crops of Quality Fruit at an early age that means the highest price in the market.

\section{GRAFTS OF QUALITY}

Our Grafts of Quality are made from above French Crab Seedlings with select scions. The workmanship must be first class regardless of expense. Every graft is wrapped solidly with wrapping machine to prevent Crown Gall and insure perfect union. Compare with these the ordinary grafts put up in many cases out of cull seedlings which nurserymen are unable to sell on the general market; scions out of old scion orchards or from cull trees out of nursery row, wrapped by hand only barely enough to hold the scions together. Millions of these inferior grafts are made and sold annually to nurseries who are either not equipped to do their own grafting or are seeking cheap material in order to grow cheap trees.

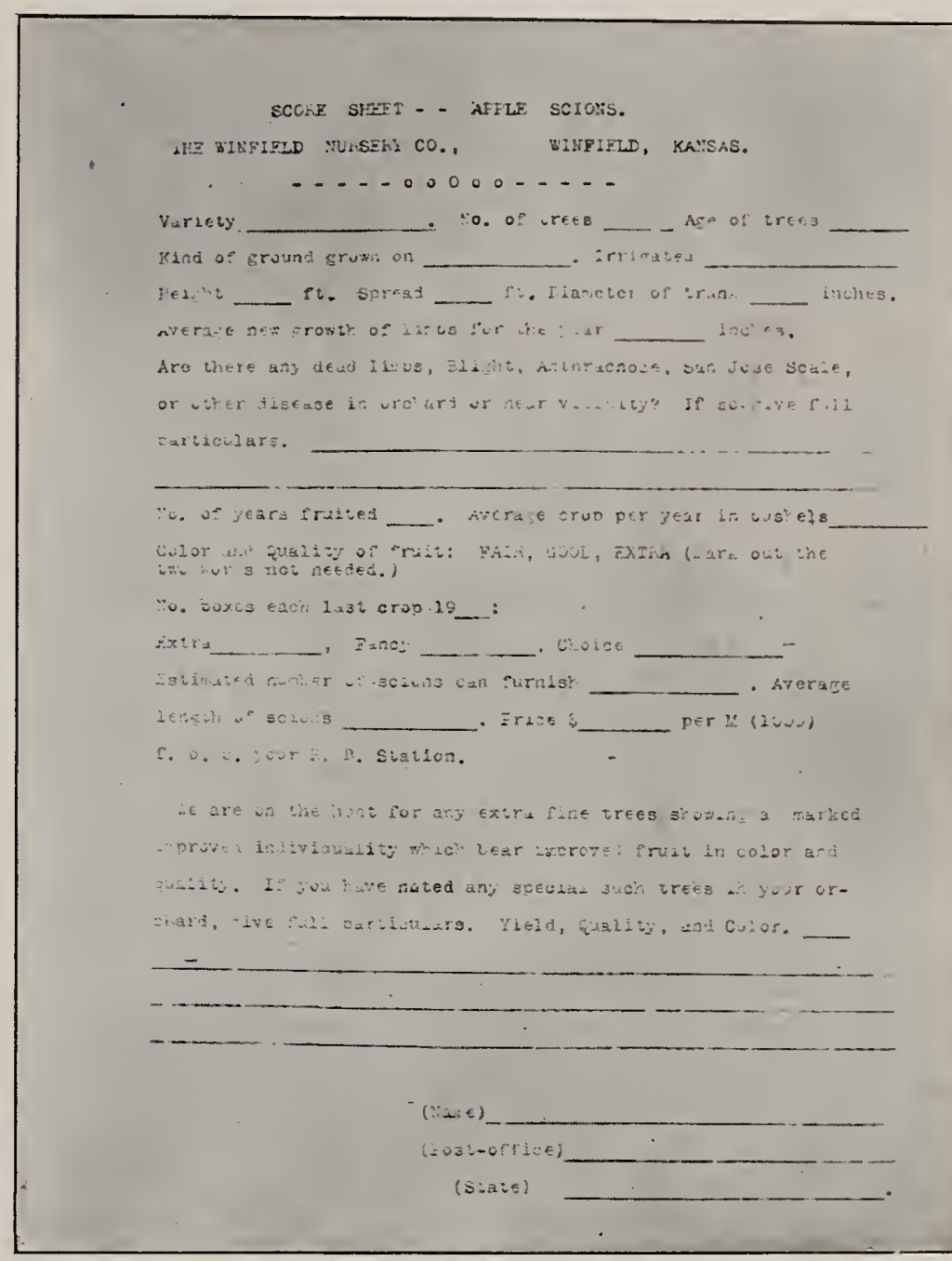

Score Sheet used in Marking Trees to Propagate from for the Winfield Nursery Trees of Quality.

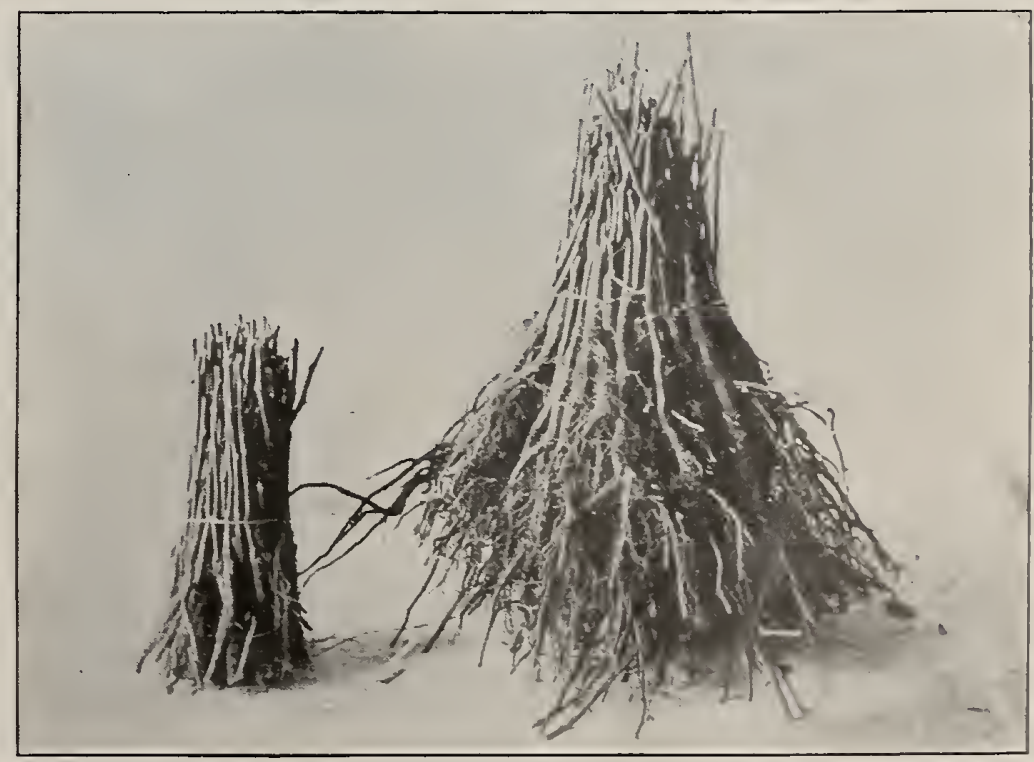

Showing 100 Ordinary Root Grafts compared with 100 Winfield Nursery Grafts which form a foundation for their Trees of Quality. 


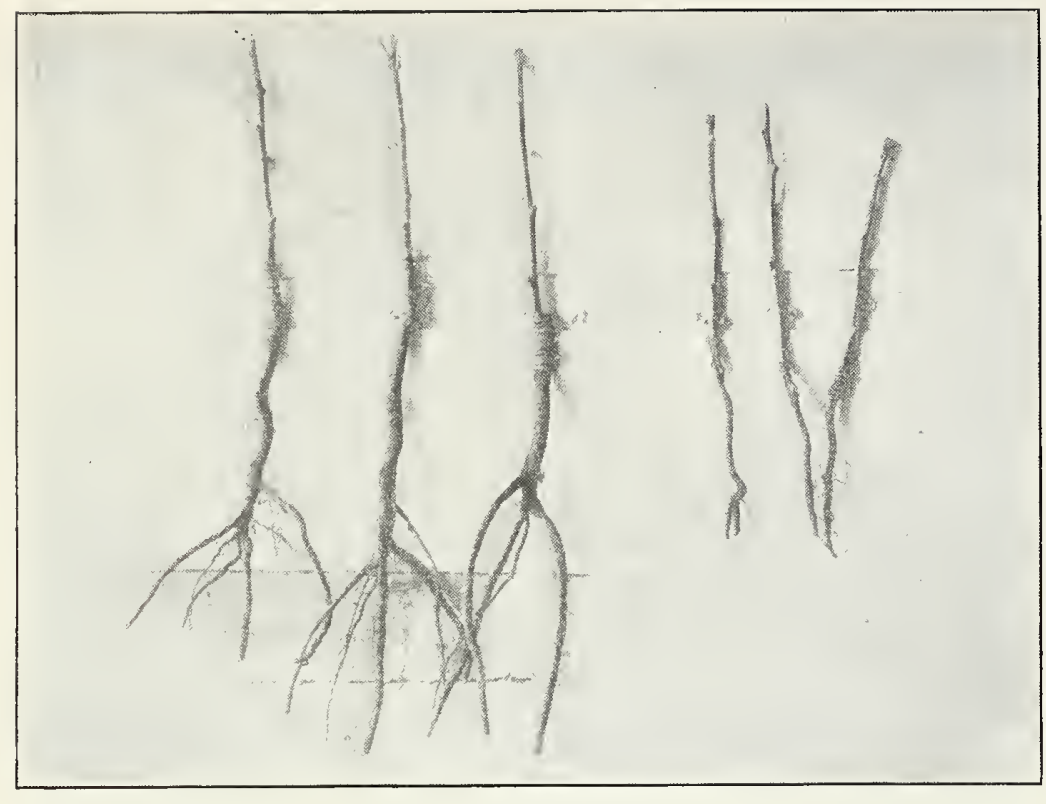

Note here the Winfield Nursery grafts of quality showing complete wrapping. On the right are shown ordinary grafts wrapped only enough to hold union.

Ordinary Scions: Ignorance on the subject of propagation is the cause for the mistakes that account for over 50 per cent. of our worthless crees. The utter indifference to the planter's welfare and greed for the almighty dollar is responsible perhaps for 49 per cent. more of the cheap trees. The rush of the present commercial age and the tendency to do things "A 11 at once" is another chief factor. There are $\mathrm{millions}$ of scions being $\mathrm{c}$ ut from "lined out" nursery row trees which have perhaps been inbred for: 20 years and have no record for fruitfulness at all. The only excuse some nurserymen offer for cutting them is that the demand is so large that they cannot obtain select scions.

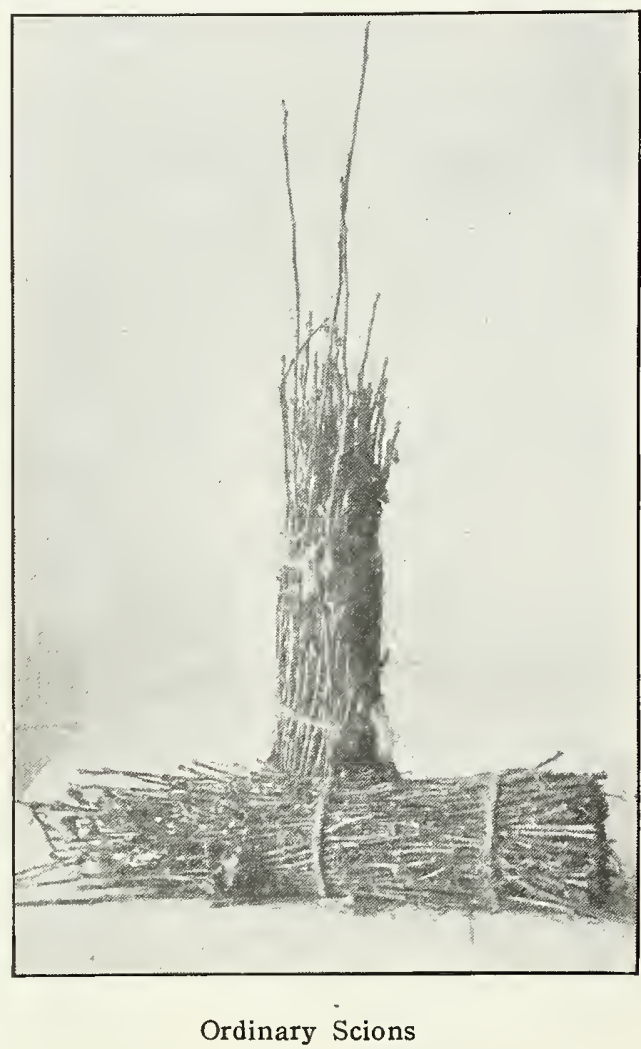

\section{WHALE OIL SOAP}

This is the greatest known agent for the emulsion or spraying of Grafts. Grafts dipped in this before planting insure absolute freedom from insects and a much more vigorous plant growth. It is also used with splended effect to spray growing trees thus insuring a healthy growth of foliage at all stages.

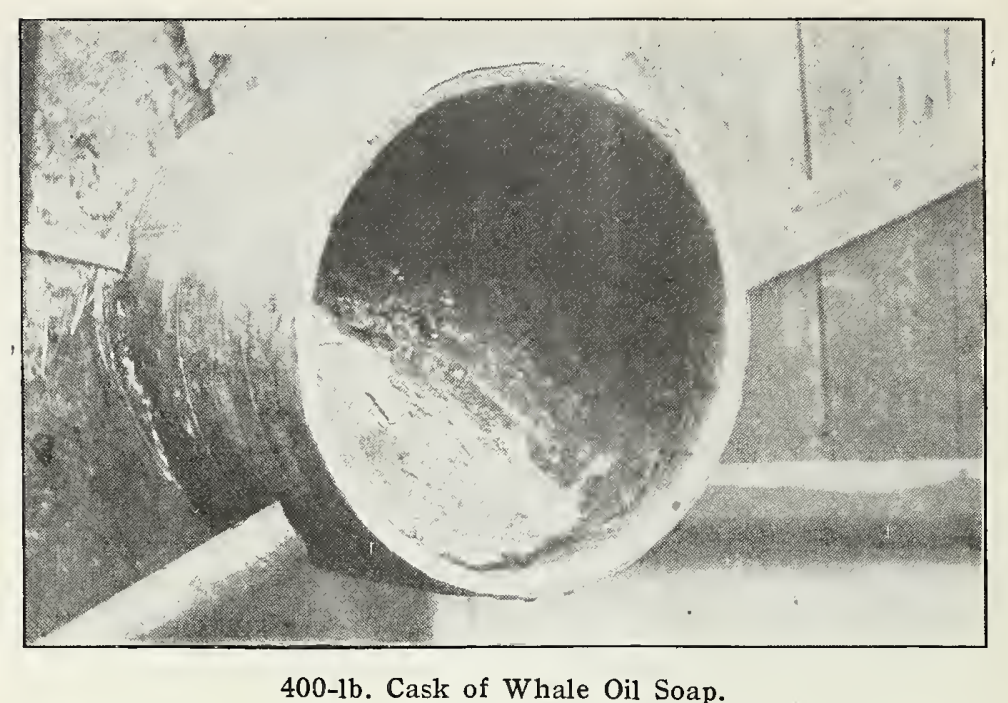

\section{WHAT OTHERS THINK OF US}

The following letters relative to our "breeding up" will show what those in high authority think of our effort to "Grow Better Stock every Year."

\section{UNITED STATES DEPARTMENT OF AGRI- CULTURE}

BUREAU OF PLANT INDUSTRY

FIELD INVESTIGATIONS IN POMOLOGY

Washington, D. C. Nov. 22, 1909.

The Winfield Nursery Co.,

Winfield, Kansas.

\section{Gentlemen:-}

Your letter of November 6th addressed to the Hon. W. M. Hays, Assistant Secretary, also Secretary of the American Breeders Association, has been referred to Mr. W. A. Taylor, Pomologist in Charge of Field Investigation, so far as it relates to the matter of propagating nursery trees. Mr Taylor is absent on an official trip to Panama, hence the letter comes to me for attention.

In connection with this matter, I do not know that I am able to add anything myself to what I have previously expressed to Mr. Moncrief, President of your Company. I regret that Mr. Taylor is not here to give this matter personal consideration.

It is, of course, a matter of common observation that particular trees of a variety in almost any orchard are known to produce fruit that is of a particularly high grade type of the variety. Likewise, other trees frequently are known to be very unproductive or in other ways do not conform to a desirable type of the variety. When it comes to the possibility of such trees perpetuating their characteristics, it is true that we do not have as much definite information concerning this point as is desirable. We know, however, that the breeders of animals of all kinds in selecting their individuals to breed from choose those that conform most nearly to the type that they desire. It is very largely by adhering to such principles as this that the greatest advancement in the breeding of animals has been made. The theory is certainly sound that a similar course in the breeding of plants and in the selection of types to propagate from may be expected to give correspondingly satisfactory results. 
We have every reason to believe that desirable results would come from it.

In a word, I think that I may say safely that from the theoretical standpoint, the course which you are following in the selection of type varieties for the improvement of your stock is perfectly sound. I surely hope that nothing will deter you from the course which you have adopted relative to the selection of your type trees from which to propagate your nursery stock.

I am sending under separate cover three photographs of the raspberry which originated in $\mathrm{Mr}$. Kleinsteiber's yard. I do not refer to it as the "Winfield" because I am not sure that you have decided to introduce it under this name.

Yours very truly,

H. P. GOULD.

Pomologist in Charge of Fruit District Investigation.

\section{THE AGRICULTURAL EXPERTS ASSOCIATION (INCORPORATED)}

504 TRANSIT BLD'G 5-7 EAST 42ND STREET

George T. Powell, President.

Cyrus C. Muller, Vice-President.

Charles H. Plump, Treasurer and Secretary.

Mr. J. Moncrief, Pres.

$$
\text { New York, Dec. 28th, } 1909 .
$$

Winfield Nursery Co.

IVinfield, Kansas.

My dear Sir:-

I) I have been for more than twenty years working along the line of obtaining strong, vigorous, productive trees through the principle of selection of buds and scions taken from ideal, typical trees, with a known record of their production and general good qualities.

The Tomkins King while an exceedingly choice apple is defective, as a tree being most subject with attacks' of apple canker. I have top worked the Kings, Scions, taking them from trees that had reached 30 years of age in good condition, and have worked them upon the Northern Spy stock, and have not a defective tree on my place from those so top worked twenty years ago. Usually half of the Kings will die out in fifteen years.

I am thoroughly convinced that there is great value in selecting buds from well known bearing trees and building up a Nursery stock in this way, and consider it very much more valuable than where buds are taken promiscously from immature trees in the Nursery Row/,

I take pleasure in sending you Brochure showing the general work which I am doing and I advise this manner of selecting and purchasing trees from this kind of propagating. Very truly yours,

THE AGRICULTURAL EXPERTS ASS'N. George T Powell, Pres.

\section{YOUR CO-OPERATION WANTED}

You Progressive Fruit-Grower. This is a personal word to you requesting that you make a thorough study of your own orchard. While you are doing this, if you observe any varieties showing trees of marked and improved individuality, kindly notify us of your observations. Proper compensation will be allowed you for your trouble. We will appreciate greatly any aid you may render toward the improvement of Winfield Trees of Quality.

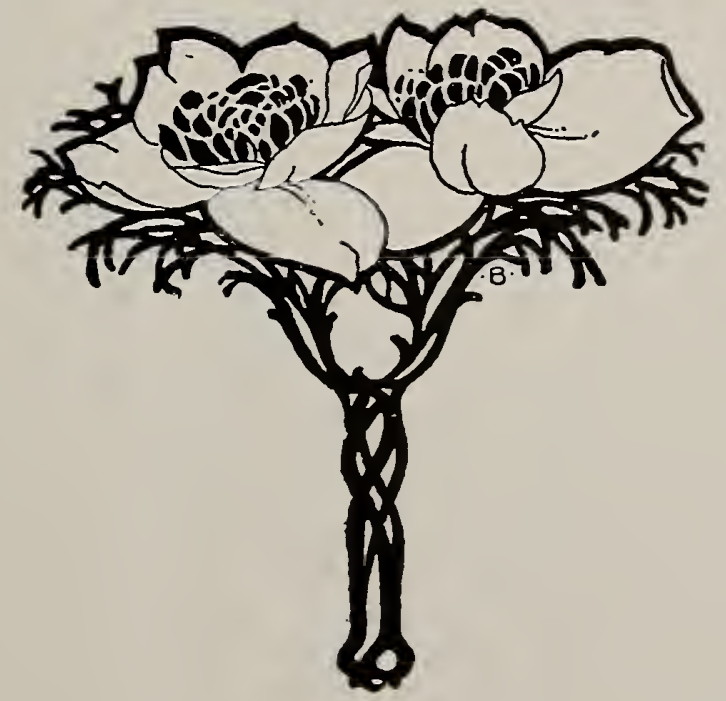




\section{A P P L E}

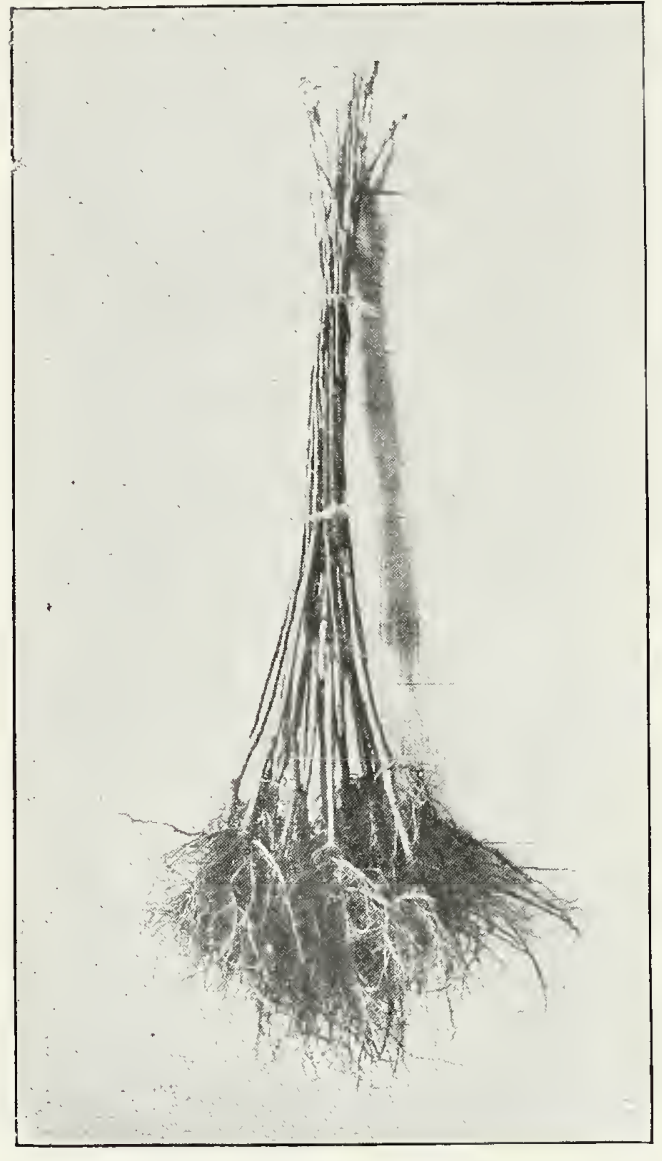

One Year r. $_{\_}$to 3 Foot Apple Trees of Quality
One Year Apple Grafts. Not the size of the tree, but the breeding that counts and insures healthy, vigorous and superb root systems. Growing demand for Winfield Nursery Trees of Quality of smallest size.

Foreman of Edward W. Genter of Denver, Colo., who has set hundreds of acres of apples, reports smallest size one yeargrafts coming into bearing before la rge two year trees.

While some locations prefer two year trees, many will plant one year only. Write us description of your land and we shall give information that will enable you to make best success. Or we will plan your orchard free as fully explained under "Special Information."

One Year 12 to 18 inch Trees. Formerly this size was considered too small to give best results. Many now prefer these. This size produces the finest quality with the best root systems. Reason of smaller size is on account of grafts, being planted late in the spring or being grown on an upland soil that produces a slower but hardier and more solid growth.

Last year we sent out a number of small one year grafts for experimental purposes, complimentary with other orders. All that we have heard from have given eminent satisfaction. We give here letters from two Utah customers on irrigated lands. These letters are a fair sample of many that we receive. Small one year trees of Quality bear more quickly than large two year old ordinary trees.

Ellis Rosecrans of Green River, Utah, to whom we sent small one year Apple reports that all did first class and that they grow better than large trees; started immediately after transplanting at least two weeks in advance of large trees that were transplanted at the same time. He has ordered several hundred more one year old trees for the spring of 1910 .

\section{A Big Planter's Opinion on our one Year Trees}

\section{“To The Winfield Nursery Co. Winfield, Kansas.}

Gentlemen:-

In answer to your inquiry asking me how the twenty small yearling apples did, which you sent me complimentary, I wish to report that I had a 100 per cent. stand of them and further they started to grow more quickly than the two year old trees, and made an excellent growth.

I want you to fill all the apple in my $\$ 500$ order this year with that kind of trees.

$$
\text { Yours very truly, }
$$

\section{J. H. BRISCOE.}

Prof. J. F. Littooy, Mountain Home, Idaho, an expert horticulturist engaged exclusively in orchard planning work advises to plant only small size one year trees so that the terminal bud is at the right height for forming the base of top. He thinks the best results are obtained from small trees in which you avoid cutting back the top buds.

A Prominent Entomologist, while visiting the Winfield Nursery last summer, said: "Your two year old trees are cheaper at 50 cents each than those--. (naming average two year old trees grown by the old method)-were free of charge.

Writes to an old Customer to investigate Trees of Quality.

We present this letter through the courtesy of $\mathrm{Mr}$. Klock which speaks for itself concerning Winfield Nursery Trees of Quality-or breeding to bear.

Mr. Chas. Klock,

$$
\text { Cement, Okla., Jan. 11, } 1910 .
$$

\section{Dear Sir:--}

I received your letter asking about The Winfield Nursery Co. Have neglected to answer for which I hope you will forgive me for my neglect. Will say I have known the Winfield people for four years. I have some three year old Apple that are bearing. I have trees from other nurseries six years old that are not bearing. Wishing you success with your trees, I remain.

\section{(Signed)}

\section{A. B. HEMPHILL}

Note:- Thes e were Winfield Nursery one year old trees.

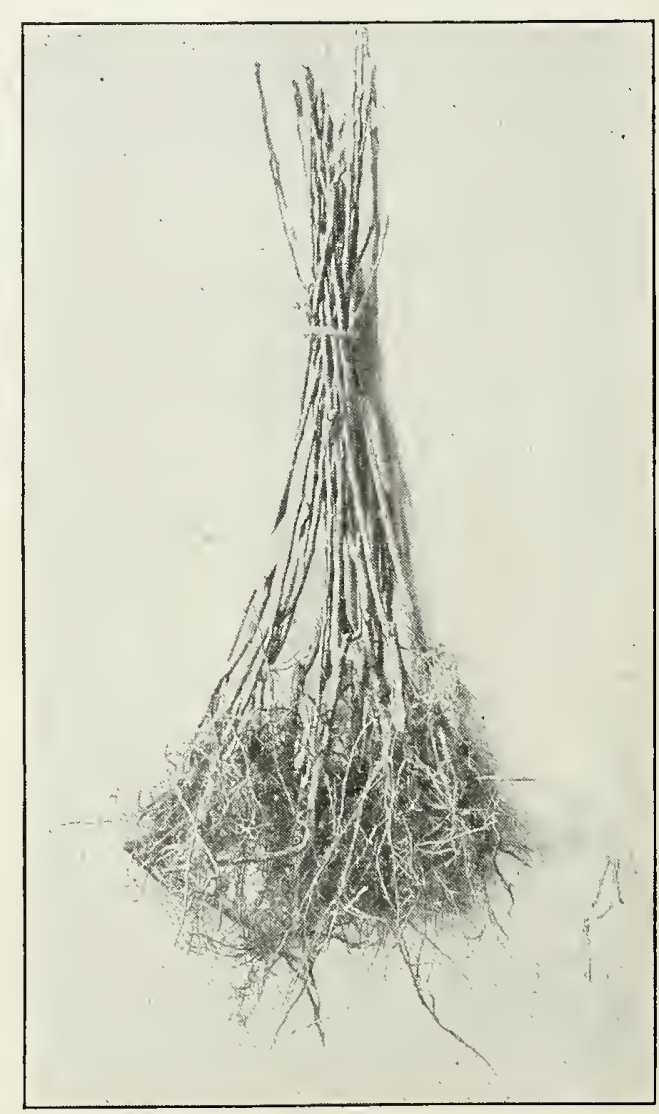

One year 1 to 2 foot Apple of Quality, better root system and bear fancy fruit quicker than ordinary two or three year old trees. 
Caution. Do not eompare The Winfield Nursery one year Apple Trees of Quality in 12 to 18 ineh and two to three feet sizes with that size trees offered by others and eulled out of bloeks which they have dug of larger size trees. There is no more resemblanee than there is between a three year old pony of 600 pounds and a one year old standard bred eolt of $(60) 6$ pounds. We guarantee our small size trees to be strietly first elass. Note stocky top and superb root system in photograph which speaks for itself.

\section{SUMMER}

Yellow Transparent-A fine light yellow apple; fruit juicy and rich, subacid. Tree hardy, upright grower; bears young and abundantly. We have seen one tree mature fifty-five perfeet apples the second year after setting. Earliest of all; ten days before Early Harvest.

Red June-Tree hardy, upright grower; medium size; red; flesh white and tender. Bears well. A good eating apple. July 1st.

Early Harvest--Medium size, flat; yellow. Tree of rather spreading habit. An old variety; bears abundantly; fine for table use. First of July following Red June.

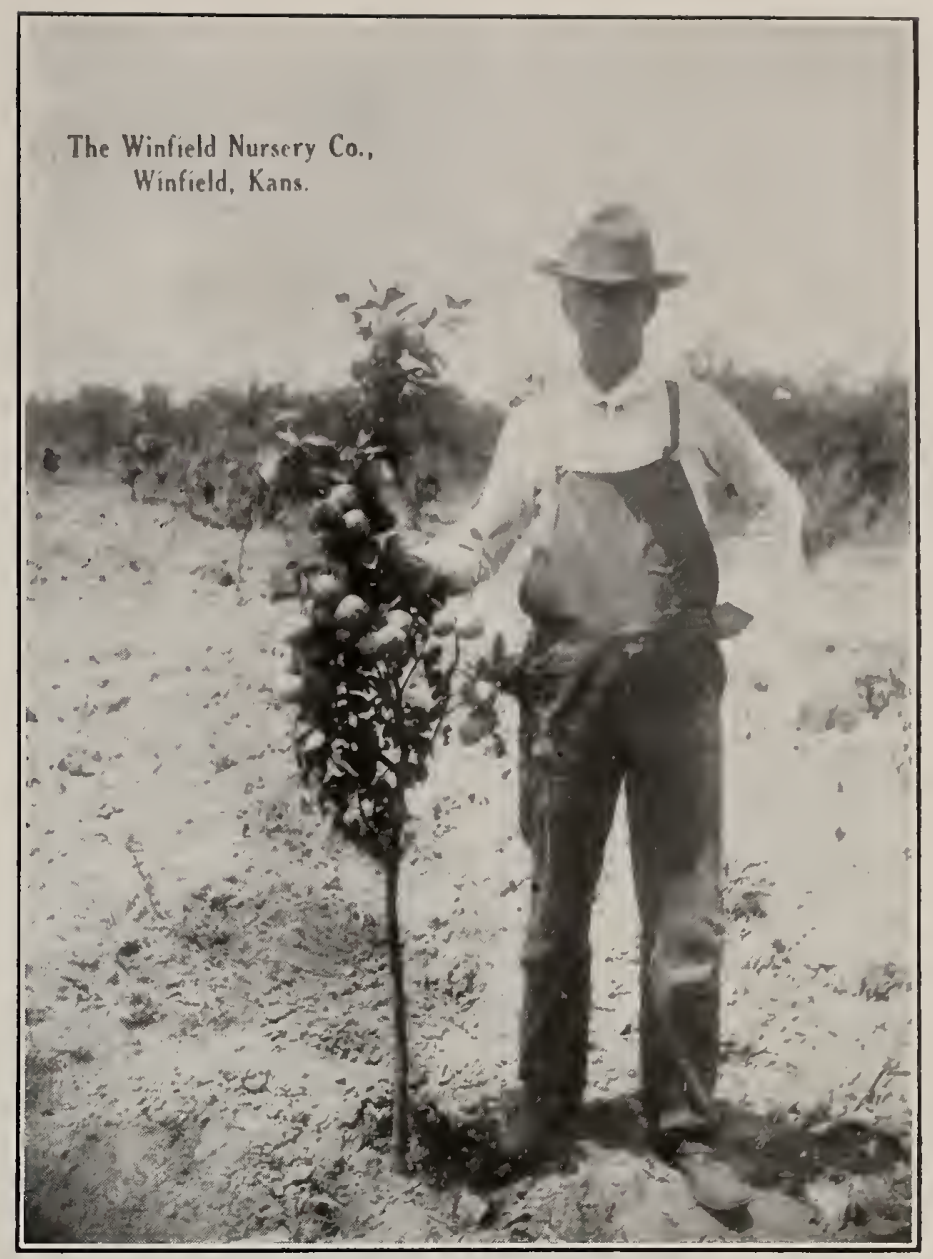

One Year Apple of A. B. Hemphill Next Year After Planting

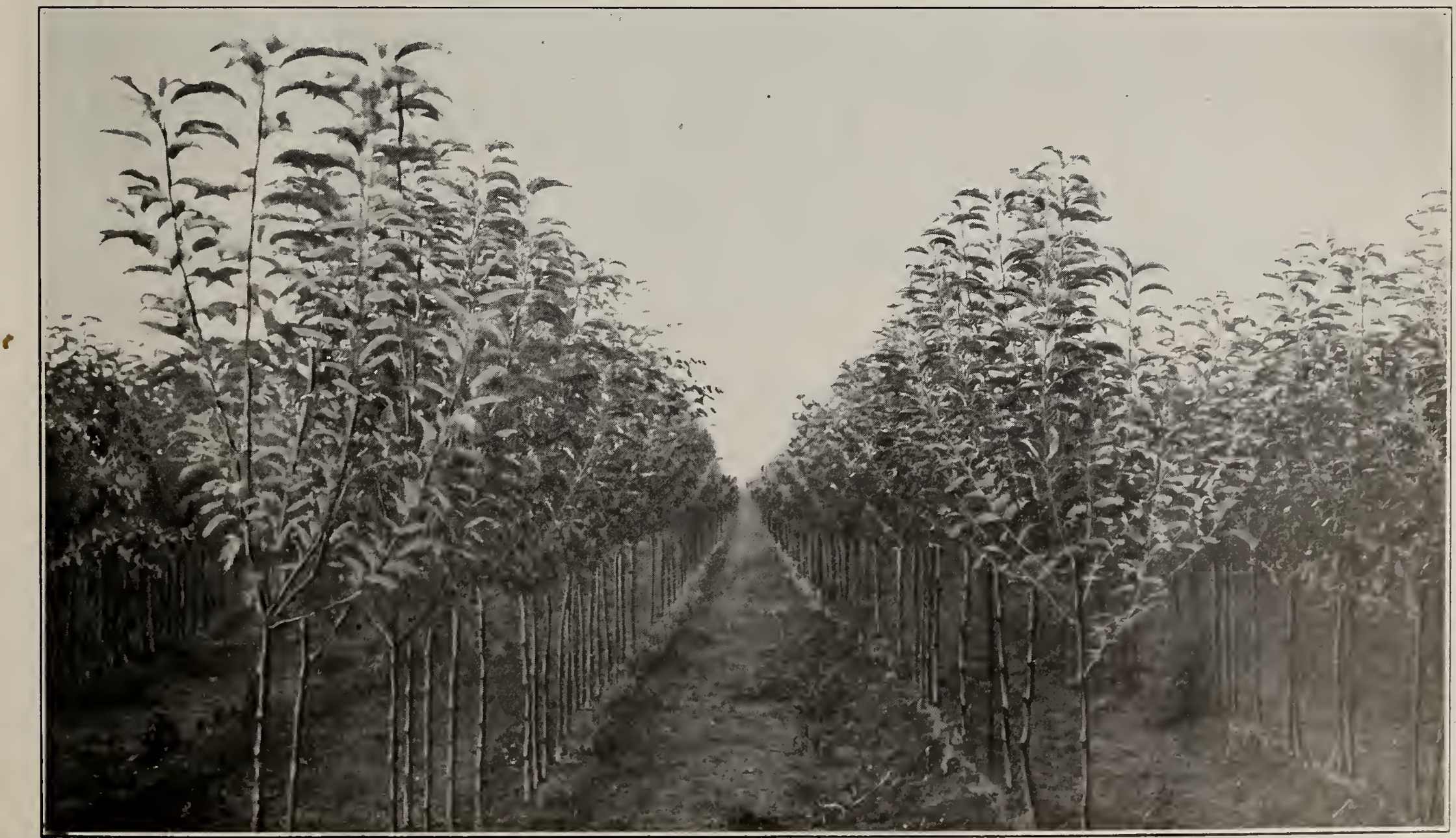


Benoni--Tree thrifty, upright growth, fruit medium size, red striped; flesh white with tinge of red near peeling, very spicy and rich. Last of July.

Sweet June-Tree a beautiful upright and spreading grower; bears abundantly. Especially adapted to the west. Fruit good size, round, greenish yellow, covered with green dots; flesh yellow, sweet and rich. Begins ripening July 1st to 10 th; lasts long.

Red Astrachan-Tree vigorous grower with very heavy foliage. Fruit large, round, nearly covered with crimson; flesh white. Acid. Ripe and green fruit often hang together. Rots bad on tree, not a heavy bearer; but highly esteemed for cooking qualities. July until August 15th.

Duchess of Oldenburg-A Russian variety that has proved hardy. Medium, roundish, streaked with red; flesh white, subacid; quality excellent. Rather a crooked growing tree in nursery row. Latter part of July.

Golden Sweet-A very large pale yellow apple. Flesh sweet and mealy. Not so prolific as Sweet June. Last of July and first of August.

Summer Pearmain--A very valuable variety, but little known. Flesh yellow, rich, highly flavored; good size, oblong, tapering to the eye, widest at the crown. Streaked with bright red. Tree vigorous; bears heavily and regularly. Fruit sells well, as it ripens at a season when good apples are scarce. July 15th to August 15th.

Cooper's Early White--Tree vigorous, but dwarfy habit; strong stiff limbs. Fruit good size; light yellow; flesh white, subacid; fine for home use and market. Best apple that can be set for southwest; bears young. Latter part of July and first of August.

One of Cooper's Early White bought of Winfield Nurseries produced forty-five apples the second year after planting, twenty-five of which filled a half bushel measure.-Wm. Hicks, Marvel, Okla.

Maiden Blush---Tree thrifty, prolific, large spreading top, long lived. A failure on high ground unless well protected, fruit being small, highly colored, and almost worthless. On bottom ground or location well protected large, flat, pale yellow, with slight crimson blush when exposed to the sun; flesh white, tender, strong subacid; stands at head of apples for drying; good market variety. August and September.

Summer Queen-Tree thrifty, fruit large, oblong tapering to blossom end, red striped; flesh pure white, rather sour, fine for cooking. August and September.

Pennsylvania Red Streak-Tree vigorous, bears well. Fruit flat, streaked with dull red. Not so rich as Rambo, but resembles it and is better suited to the West. September.
Rambo--Old, well known variety, highly esteemed for its fine flavor. Not a success in this latitude. We do not recommend it.

Wealthy - A variety rightly named. Recommends itself where known. Tree vigorous and hardy, an upright grower; bears young and very heavily. We have gathered apples from two-year trees in nursery row, and have reports of four-year trees bearing two bushels to the tree. Fruit roundish, oblate; light ground mostly covered with dark red, set with white dots, smooth and glossy. Flesh white, subacid. September.

Grimes' Golden-Best quality of all apples. Round oblate; rich golden yellow color, skin rough, flesh deep yellow, fine grained, delicious flavor, spicy subacid. Tree a compact grower, very hardy, especially adapted to the West; bears regularly and abundantly. Hard to get on market at $\$ 1.50$ per bushel when other apples are $\$ 1.00$ per bushel. Should be picked in September.

Greatly in demand by commercial planters in western irrigation belts, especial increase in demand this year. Its great quality, and hardiness insure for it a great future. It should rank in number of trees with the Jonathan, Improved Winesap, Reagan and other great leaders. September to February.

Jonathan-Tree poor grower in nursery row, but hardy and stands drouth well in orchard; long lived. Fruit fair size, round, tapering to the eye; light yellow ground covered with bright red stripes, often almost solid dark red. Skin thin and smooth: flesh white, tender and juicy. A mild subacid. Fine for home use and a great market variety. Should be used as one of the commercial varieties, but like Grimes' Golden, picked early. September to November.

Smith's Cider--Recommended by some planters as a market variety. Tree blights badly. Is a failure as a western apple.

Winter Banana-Large, very light yellow with slight blush, flat shape, resembles Maiden Blush by much in form but is larger; is smoother and much more beautiful, flesh tender with a very slight banana flavor. Tree exceptionally thrifty and vigorous, large foliage and light wood. A fancy market variety commanding a high price; fruit must be handled with care.

Special Note:-A box of Winter Bananas were bought at the Denver Apple Show in January, 1910, for $\$ 52.00$ and sent to President Taft. The price per apple was $871 / 2$ cents. Winfield Nursery Bananas are bred from trees selected in the valley where these were produced.

Rome Beauty-Large, uniform in size, upright bears young, very round, almost flat; yellow ground with bright red stripes. Flesh yellow, rich, subacid, fine quality. Tree productive in the West. Especially prized in western irrigation belts as a commercial variety. October to December.

Bailey Sweet--A very vigorous, thrifty tree; bears heavily. Fruit round, slightly oblong tapering to the eye; a bright red with darker red stripes; flesh white, a sugar sweet. October to December. 


\section{WINTER}

Ben Davis-This old variety is still one of our leaders in commercial orchards. Fruit large, round, conical; light ground almost covered with bright red stripes. Flesh white, tender, subacid; quality fair. Tree perfectly hardy, long lived and a heavy bearer, fruit even size, good shipper and fine color. These points combined are greatly in its favor for large planting. November to April. Should be planted heavily in commercial orchards on account of standing at the head of the list for long export shipments.

Missouri Pippin--Tree perfectly hardy, stands drouth and wind better than other apple. Bears young regularly and too heavy, bears at least two years earlier than any other variety. Tree usually short lived on account of over-bearing; fruit good size, and large if thinned; flesh white, juicy; quality only fair; light ground covered with bright red stripes, often quite dark. Should be planted heavily as a commercial variety. December to April.

Winesap (S I L V E R MEDAL)-Very popular on account of its fine flavor, bright red in color wit h beautiful dark shade in the large improved strains. Tree perfectly hardy; fruit of old Winesap medium; Improved Winesap.very large. Fruit now in our office averages in size from $10 \frac{1}{2}$ inches to $10 \frac{3}{4}$ inches in circumference. The Winfield Nursery Winesap is bred up from Silver Medal strains and fine western trees. This should be one of the great leaders in commercial orchards. November to March.

Mammoth Black Twig--Coming forward every year. We believe after it becomes known it will be king of the West. Tree hardiest of all varieties; large spreading top; abundance of foliage; bears regularly and abundantly long lived. Fruit large, round, oblong, yellow ground covered with dark bright red sometimes almost black; very showy, flesh yellow, juicy, quality resembles Winesap. Quality, hardiness, beauty and productiveness all combined in this apple. November to April.

$\$ 81.50$ Profit from one tree of Mammoth Black Twig in 1907--Geo. W. Winn of Palisade, Colorado, reports that in harvesting his crop of Mammoth Black Twig apples in the fall of 1907 that his trees averaged something like 25 bushels, for which he received $\$ 2.60$ per bushel, while one tree produced 33 bushels, which sold for $\$ 2.60$ per pushel or $\$ 2.47$ net to $\mathrm{Mr}$. Winn, which leaves him a net profit from this tree of Mammoth Black Twigs of $\$ 81.50$ for the crop of fruit of 1907 .

York Imperial--Fruit medium, oblate; flesh firm, juicy, good; light color, shaded with crimson. Tree hardy. November to February.

Stayman. Winesap-Originated at Leavenworth, Kansas, by Mr. Stayman. Fruit covered with small dots; similar characteristics to common winesap, color high, meat yellow, bears very heavy, large size. Thought by many to be improved Winesap to which it is very similar in fruit. A great favorite especially in high altitudes and western irrigation belts. Fruit always commands a premium price. One of the leaders in commercial plants.

Gano--.Often spoken of as improved Ben Davis or Black Ben Davis to which it is very similar, as it comprises all the good points of Ben Davis in hardiness; bright red in color; flesh firm and sweet. One of the leading commercial varieties. December to April.

White Winter Pearmain--Tree hardy. Fruit medium to large; oblong conical in shape; light yellowish gree $\mathrm{n}$ covered with very small brownish dots in color; flesh very crisp, tender, juicy and delicious. Especially noted as a fine table variety. One of the most highly esteemed apples among commercial growers for a fancy variety.

Reagan--A beautiful apple, solid bright red. Largest of the Ben Davis family, and thought by many leading horticulturists to surpass all others of the Ben Davis family. Trees thrifty. Four year old trees with bright green foliage and loaded to the ground were seen by us at Green River, Utah, last year. It was a picture that would have made a beautiful painting. This great apple is an old variety, the splendid quality of which has been realized by the Winfield Nursery. This is the variety we refer to under "Special Information" as a leader in the great export market which is so essential to commercial orchards. It is always hardy and never fails to mature a large annual crop, where other winter varieties grow. The most beautiful, oblong blood red apple in the market. Quality and Solidity put it at the front for export market. 


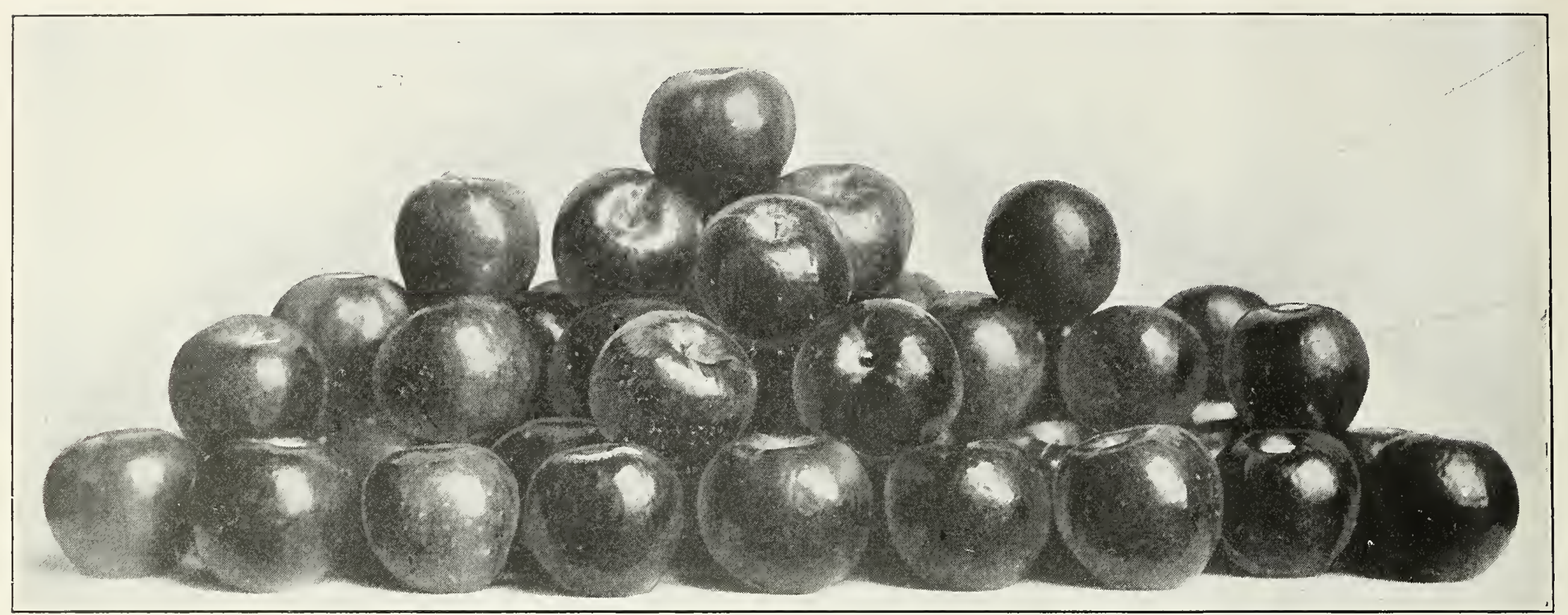

Bushel of Reagan Out of Our Orchard at Palisade, Colo., Contained 64 Apples, Averaging Almost 14-oz. Each.

Ingram-Small, noted for late keeping; tried in this locality, but not recommended. January to May.

Arkansas Black--In color very dark red, almost black; good size, quality good, keeps long. Tree hardy, bears light in this locality and north. Recommended for Northern Oklahoma and New Mexico planting. December to May.

Janet-An old variety, well known. We do not recommend it for western plaṇting.

Romanite (Gilpin CARTHOUSE) - Fruit. medium size; light ground streaked with red; mild subacid, rather sweet; quality second class. Valuable as productive and a late keeper. January to June

\section{APPLES SUITED TO SPECIAL LOCALITIES}

Spitzenburg-Large oblong, yellow back-ground, striped bright red, very attractive. Flesh yellow, subacid, juicy and rich, quality extra. Especially adapted to Oregon, Washington, Canada and other

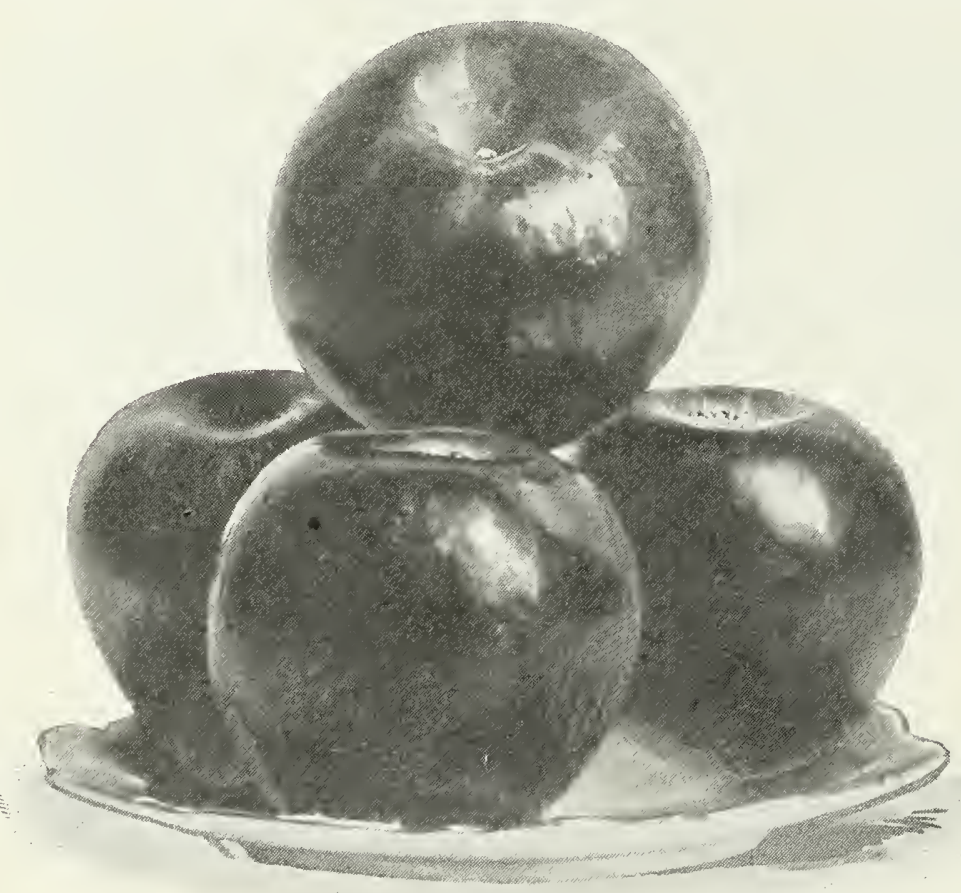

Plate of Reagan, the Apple that is Pure Gold for Commercial Planters localities; not recommended for general planting. Very profitable commercial variety where successful.

Newton Pippin -- Very large, golden ye $110 \mathrm{w}$, smooth skin, fine grain, flesh rich, crisp and juicy, flavor extra; very desirable for fancy market. Succeeds only in limited territory, especially in Pacific coast states and Canada.

McIntosh Red - Large showy red, very attractive, quality extra; one of the leading commercial varieties in Montana and other northwestern states. Trees hardy, bears annually. Select scions from Northwestern bearing orchards.

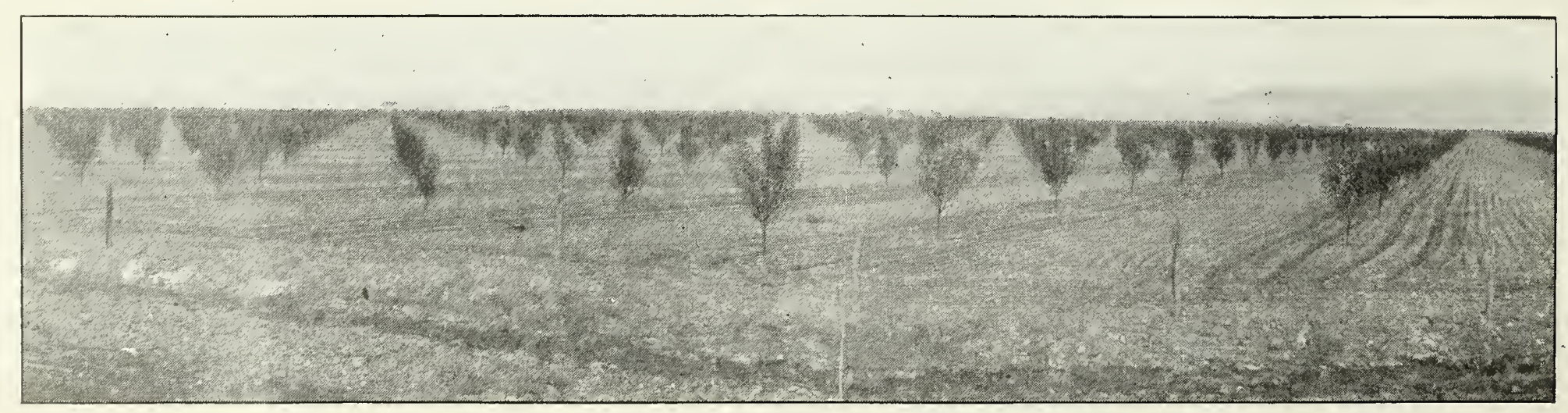

50 Acres of 1-Year Old Winfield Nursery Trees of Quality 2 Years After Planting. Perry Spratt's Ranch, Clifton, Colo. 
Collins (Champion) -- A bright red color. Fruit good size on young trees; old trees inclined to run down in size by heavy bearing. A late keeper. Arkansas Agricultural Experiment Station.

Oliver (Senator) - The crops from trees of this variety were rather disappointing the past season, as the apples were quite small on account of over production; however, they were all well colored and kept well for a fall apple. There are some complaints regarding the unhealthfulness of the trees of this variety. This is not general enough to attract attention although it might be well to thoroughly test the variety before planting it largely. - Arkansas Agricultural Experiment. Station.

\section{CRABS}

Florence - A crab larger than the Transcendent. Color

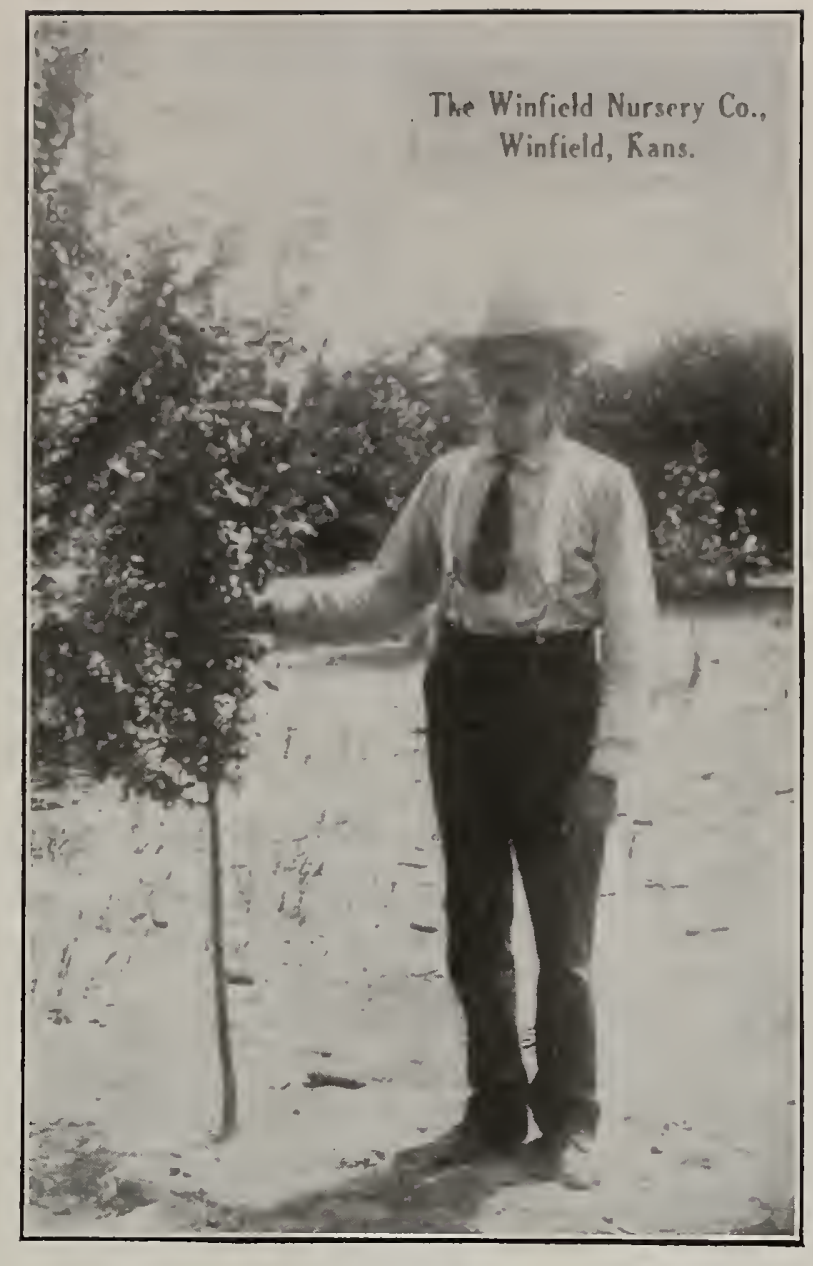

FLORENCE beautiful yellow background striped. with rich red; quality excellent; season early; bears young; tree thrifty. Thoroughly tried in this section. Better than all the other crabs.

Whitney - Tree vigorous, thrifty and very prolific; fruit largest of the crab family; light green, striped and almost covered with bright red; flesh mild, juicy. July.

Transcendent--Tree a vigorous grower and prolific, but is bothered with some blight. Fruit well known, fair size; straw color with red stripes when exposed to the sun. Flesh crisp and juicy. Very fine for all purposes. August.

Hyslop-Tree vigorous grower. Fruit large, a deep red color, almost black. Flesh mealy, good for jelly and preserves. September.

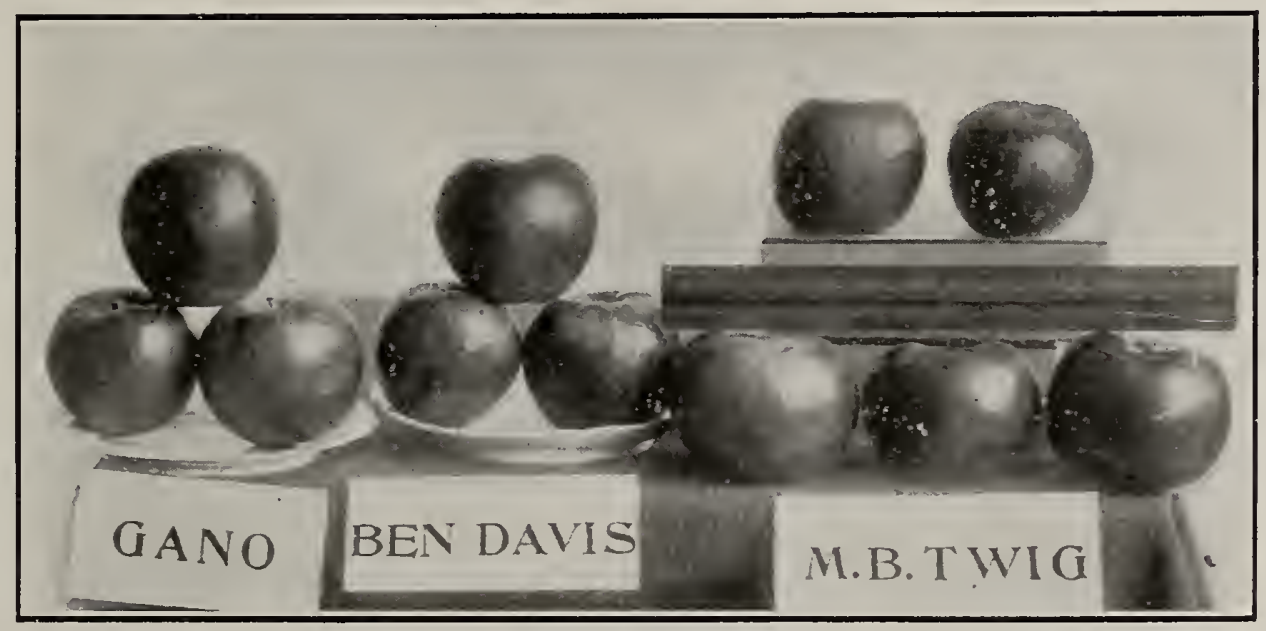

APPLES OF QUALITY 


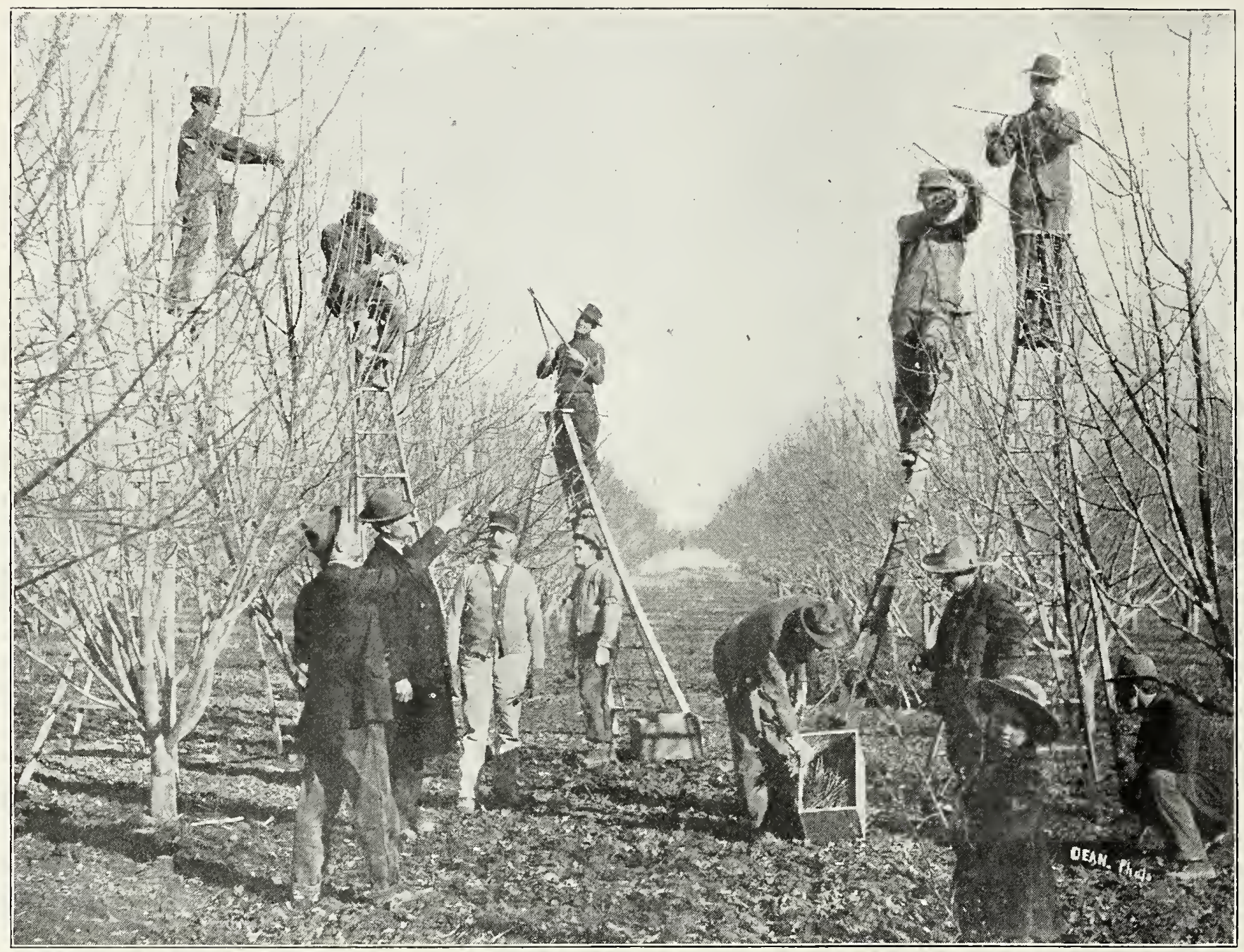

Cutting scions for The Winfield Nursery Trees of Quality from premium trees. Only well developed terminal fruit wood is used for the purpose of insuring quality and young bearing trees

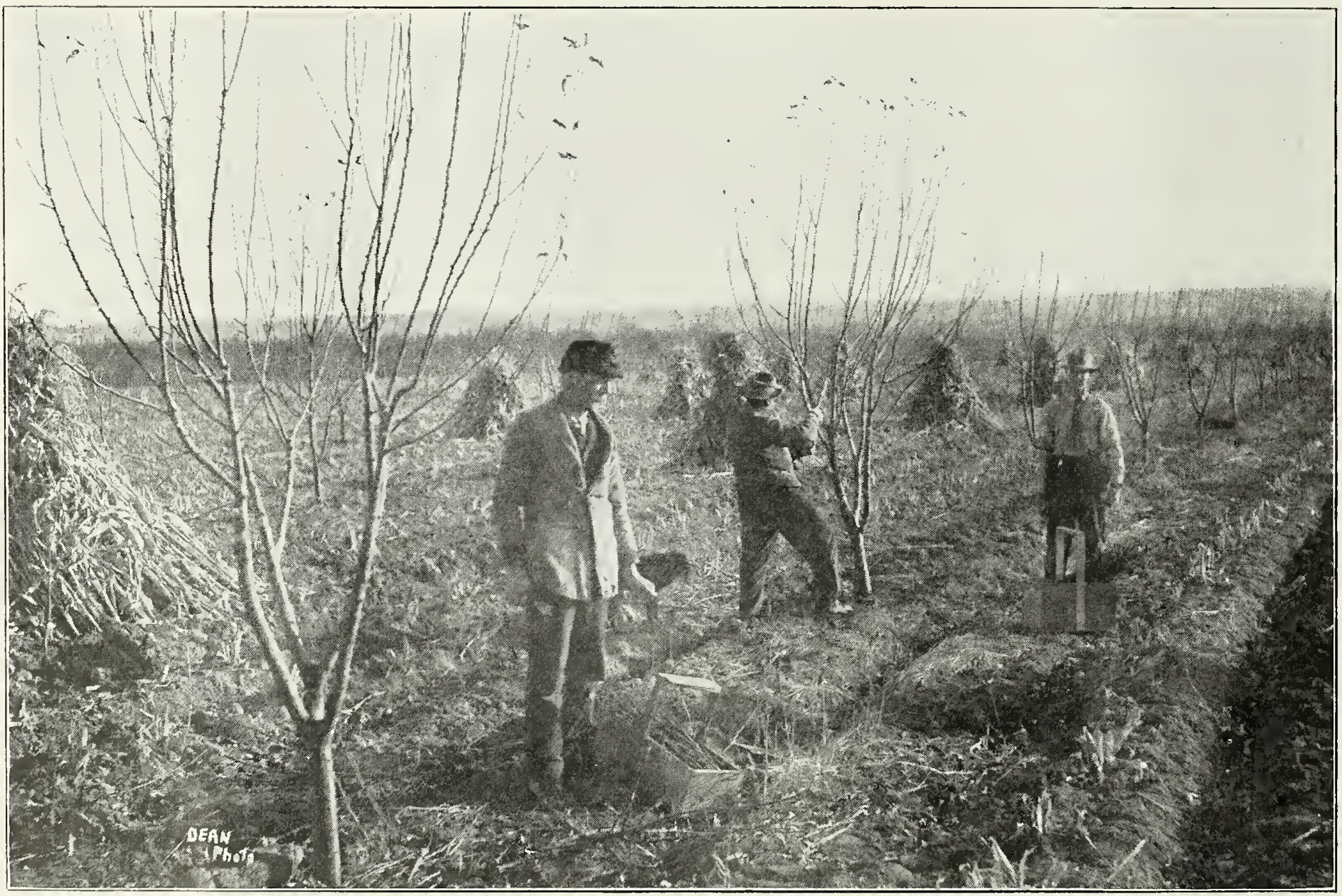

Snap photograph of ordinary scion cutting. This cutting is largely wate

sprouts from young orchards, whose fruiting qualities are unknown

These scions will average four grafts each or grafts at one-tenth the cost of Winfield Nursery Grafts of Quality 


\section{PEACHES}

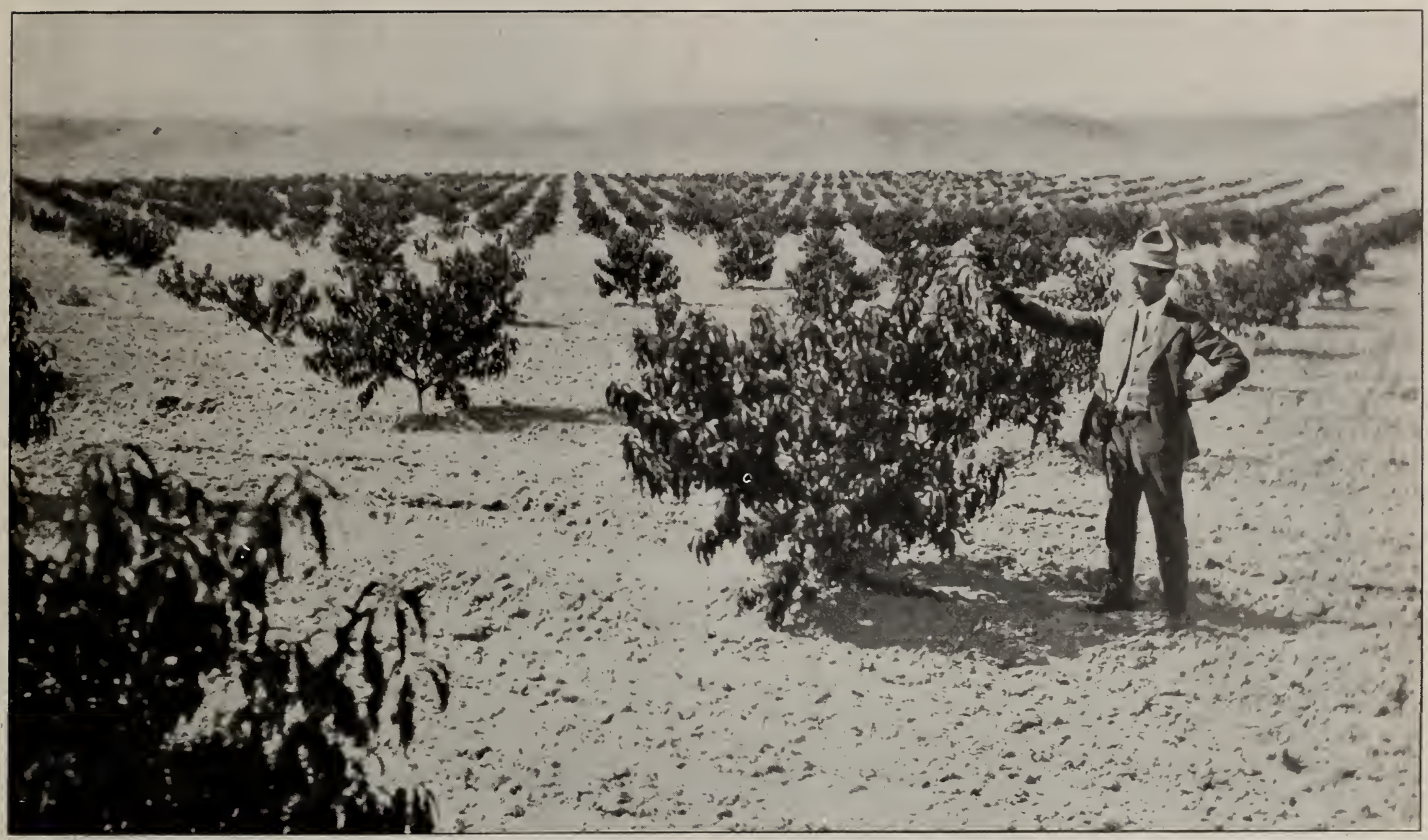

Partial View of 34,000 Peach Trees of Quality in One of Our Own Irrigated Orchards at Green River Utah. E. A. Bricker, shown in this Photo, is Secretary of The Green River Fruit \& Land Co.

Note:-All varieties are freestones unless otherwise noted.

Our soil and climatic conditions are peculiarly adapted to the growing of stocky, vigorous, well rooted trees. One of the leading nurserymen of the United States who makes a specialty of peaches, was in our field this fall when we were digging a block of 30,000 Hottes Elberta. His words were: "Splendid! Perfect! Could not be grown better!"

Select, small natural seed give us hardy, budding stock. These are budded to select buds from best inindividuals of each variety and are grown in locality where peach disease of any $\mathrm{ch}$ a $\mathrm{r}$ a cte $\mathrm{r}$ is unknown. These conditions explain the great demand for Winfield Nursery Peach Trees. Our prices for Peach Trees of Quality are in some instances double the prices asked by others for trees that have been grown in the cheapest way for 20 years by cutting buds from nursery row. With our system of selecting buds, you are sure of Quality and trees that are. True to Name.
Blocks of our Quality Peach trees for 1910 are now being grown in our plants at Hackney and Wellington, Kansas, and Huntsville, Ala. At the Huntsville plant alone, over 100,000 of The Winfield Nursery's now famous Hottes Elbertas are being grown, besides other leaders.

Amsden-Medium size, color red, shaded with dark red; flesh white, juicy and sweet when fully ripe. Very productive and regular bearer; semi-cling. June 15 th to 20 th.

Sneed-A Seedling of Chinese Cling; white with delicate red cheek. Has proved a success here. Not subject to rot. Ripens with earliest. Tree spraw1ing growth. June 15th to 20 th.

Arkansas Traveler--Fair size, white, about half covered with red; juicy, sireet, semi-cling. June 20 th to 25 th.

Japan Blood Dwarf-Medium to light, resembling Arkansas Traveler in shape; beautiful red in color; flesh white with red juice, which causes the flesh 


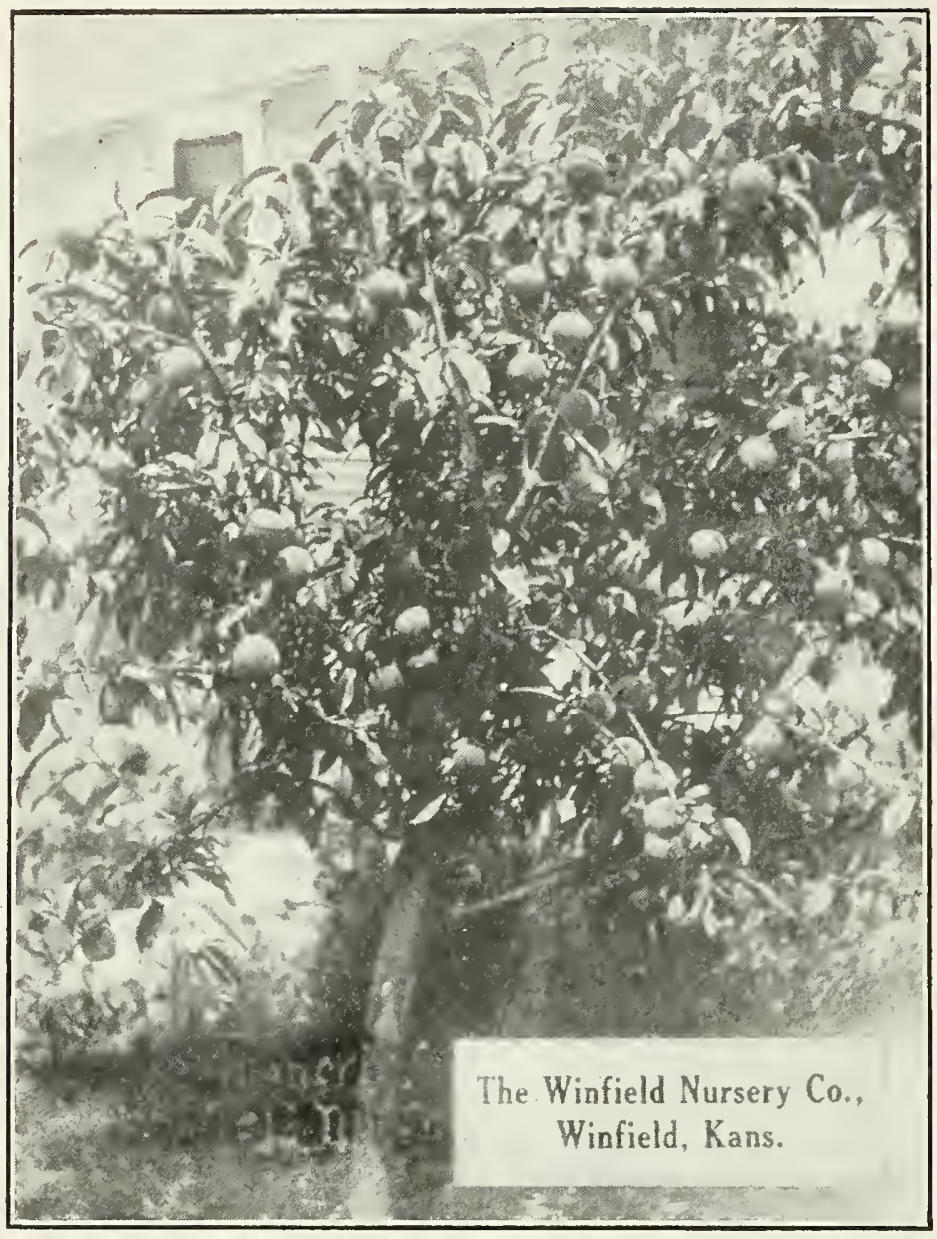

Japan Blood Dwarf Tree on Our Home Place Matured 2 Bushels Second Year

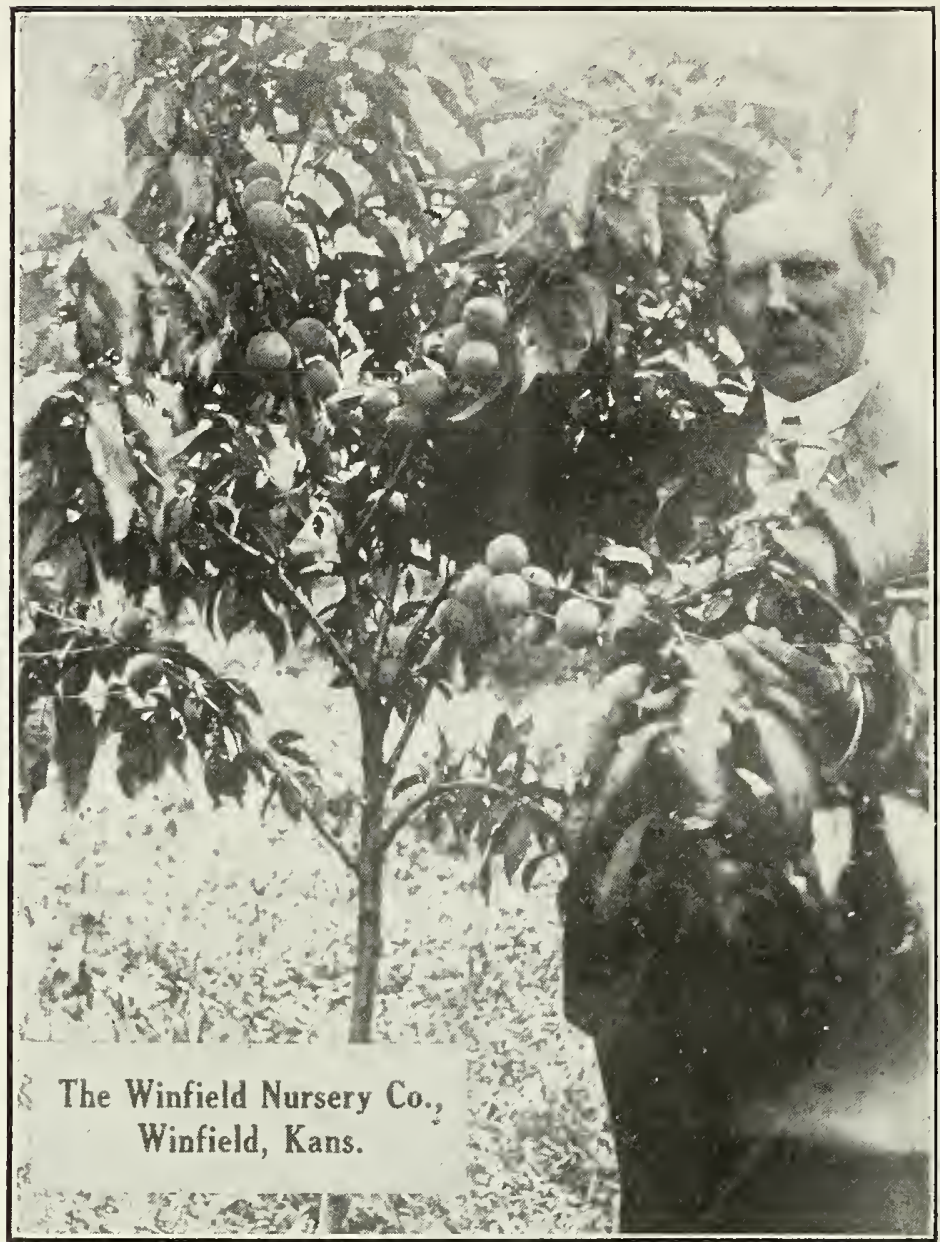

Japan Blood Dwarf Tree of W. R. Frazier, Winneld,
Kansas, Ripened 92 Peaches Next Year After Planting

We recommend this tree as one of the most satisfactory trees for yard or city planting, as it is a dwarf grower. Season last of June. Tree hardy, dwarf pit; pit small; flavor of peach rich, making it a very desirable variety for table use and also a fine variety for canning. The best and only general purpose early peach grown. Ripens a week to ten days after earliest peach, or last of June. This wonderful peach is now being introduced in this section and has proved to be one of the most valuable fruits for planters ever introduced in the line of peaches. Trees always bear the second year making them the youngest bearing fruit tree that can be planted.

Note.--R. M. Williams of Winfield, Kansas, reports to us May 12, 1908, that his Japan Blood Dwarf Peach planted from us last year bore 123 peaches this year.

W. R. Frazier's tree planted in 1905 , picture of which is shown in upper right hand corner, had on 62 ripe mature peaches when this picture was taken in 1906.

Mr. Blakely, Burden, Kansas, who was one of the first planters to try this peach, purchased more trees of us, stating he could not afford to be without this variety if they cost him $\$ 5.00$ each.

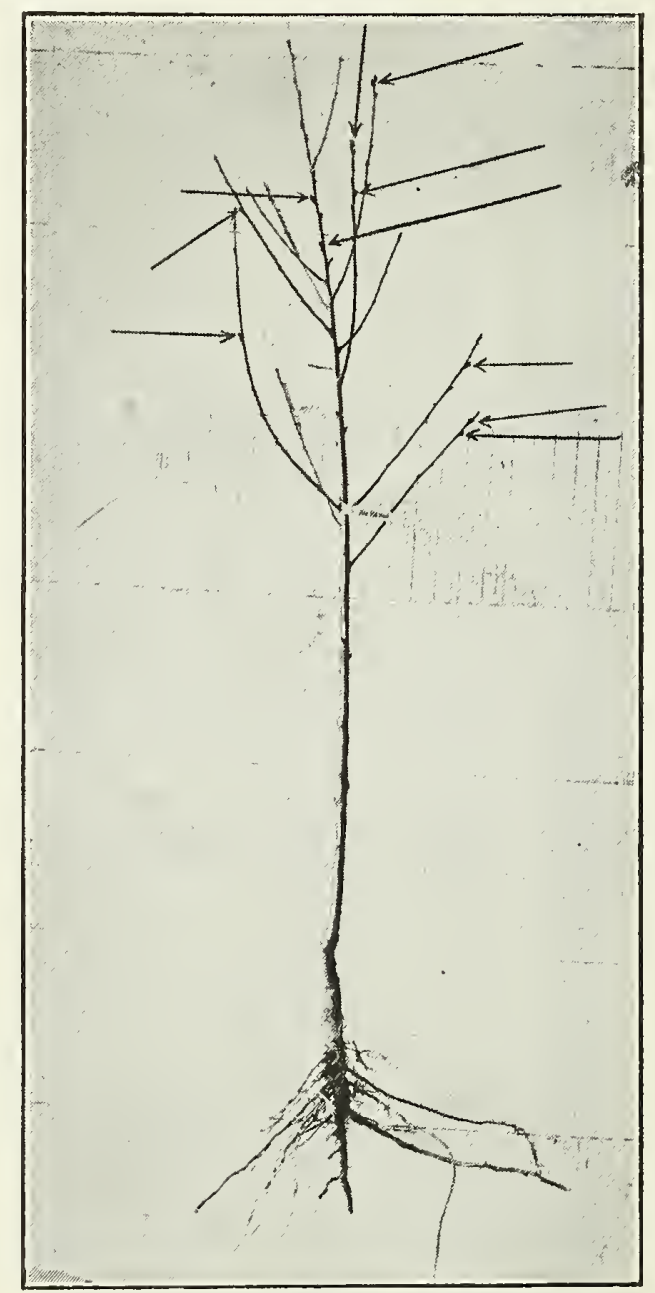

Japan Blood Dwarf. 1-Year Old habit, and though making a good tree, not so tall as other varieties.

Plant this Variety on Rented Land. Bears almost as quickly as a tomato vine. The Japan Blood Dwarf illustrated here is well set with fruit buds. Note the large buds which are marked. This is probably the youngest bearing fruit tree in existence and is the only early peach of best quality. It is very attractive for desstrt. When sliced it has the color of red raspberry.

Triumph -- Large; yellow with bright red cheek; flesh sweet and firm. Good shippers; productive; the best early yellow semi-free yet introduced. Last of June.

Early Rivers - Large creamy white freestone with delicate pink blush in sun; roundish oblong; flesh white to the pit, juicy, sweet and fine flavor. Very productive in the West. July 1st to 10th.

Greensboro-Large pure white freestone with delicate red blush oblong; flesh pure white, sweet and juicy, very fine flavor. This peach 
is very productive in the West and one of our best early market varieties, resembling the Champion, except an earlier season. July 5 th to 10 th.

Carman--Originated in Texas. Very showy, white peach with red blush resembling Elberta in shape. A new peach highly recommended for early season. Juicy.

Filburn--A snow white peach with red cheek, almost round; flesh fine, buttery, sweet and rich. Tree hardy and long lived. Fruit often grows in clusters at the base of large limbs. Fine for market. July 1 st to 10 th.
Foster-Large, yellow with dark red cheek resembling Crawford's Early; hardy and prolific, while Crawford's Early is a failure. July 25th to August 10th.

Yellow St. John-Large, yellow with red cheek, slightly red at stone; quality resembling Elberta. Very prolific and adapted to southern planting. Ripening just before the Elberta and on account of its great resemblance to the Elberta, it is often called Early Elberta. It is of excellent quality but when ripe will not hold up for long shipment like Elberta. July 25th to August 10th.

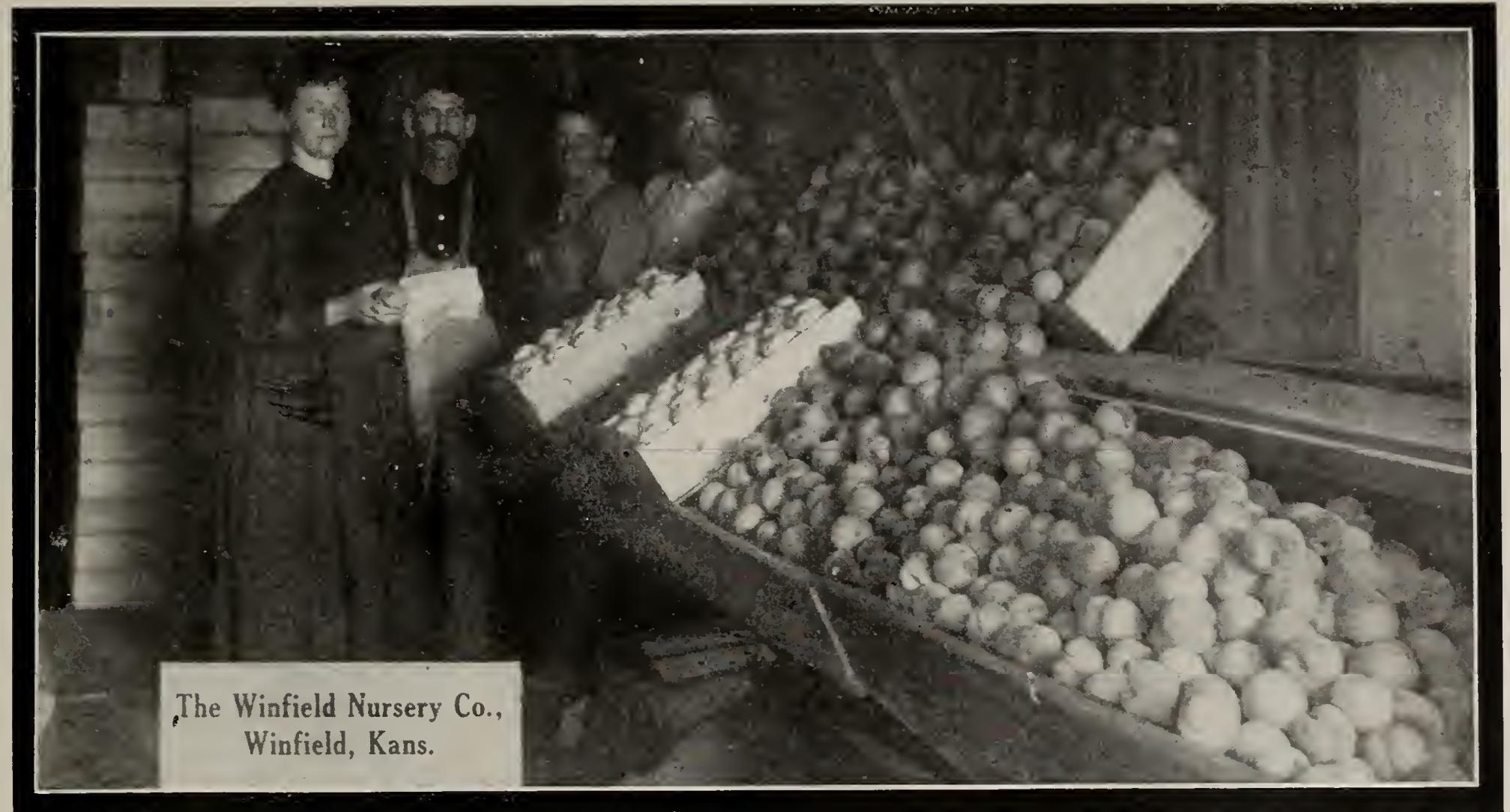

CHAMPION PEACHES Ready for Grading and Packing. Picked from Trees from which the Winfield Nursery Company Selected Buds on Account of High Quality. Grown by D. C. Overly, of Palisade, Colo.

"I have grown Filburn peaches for twenty-five years and find it the most valuable peach yet introduced in this vicinity." DAVID WILSON, Winfield, Kansas.

Mamie Ross (CLING)-White with red cheek; round very large, sweet and rich; very prolific; never fails to produce annual crop.

\section{Tree of Mamie Ross.}

After thinning off 508 peaches this tree produced 10 boxes of beautiful, large, delicious fruit. Neighbors to whom fruit was shown could hardly believe that such magnificent specimens could be grown without irrigation. Plant this variety to follow Japan Blood Dwarf. Ripens last of July.

Mountain Rose-Large, white, red cheek; flesh white slightly red at the stone, juicy, rich and sweet; fruits regular. July 25 th to August 5 th.
Champion--Large, creamy white, light red cheek; fine quality, rich, juicy and sweet. No finer whitemarket peach than Champion; noted for regular bearing. Best of all for the home. August 1st to 12 th.

Fitzgerald-Originated in the north, very hardy and one of the choice new varieties. Very large, deep yellow, small pit. August and September.

Elberta-Largest size, oblong, yellow with red cheek; flesh deep yellow, firm, juicy and rich. Best market variety known; specimens measured twelve inches around. Never knew a planter to be disappointed in Elberta. We prize it very highly because of its regular heavy crops. Bore when seedlings failed. Queen of all peaches in the Southwest. August 15 th to September 1 st. 
Elberta (HotTes)-Not a distinct, new variety but a special strain of Elberta noted among thousands of Bearing Elbertas in Grand Valley, Colo., one of the greatest Peach belts in the world. We have watched this tree carefully for three successive years and its continuous production, large, even, highly colored, fine quality fruit has been a great source of satisfaction. We have an extra stock of this improved Elberta; 100000 at Huntsville, Alabama, alone for 1910 .

Emma--A new ye 11 ow peach, thought by some to surpass Elberta, large, firm, prolific. Ripens after Elberta. Recommended for commercial planting.

Crawford's Late-Good size; golden yellow with deep red cheek; flesh deep yellow, rich and sweet. None better quality. Succeeds fine, while Crawford's Early is a failure. August 28th to September 5th.

Crosby-Originated several years ago by Hale and widely advertised as a hardy, frost proof peach, though we find it no hardier than other leading varieties. Small sized yellowish peach; rich in quality.

Bears so heavily un les severely trimmed that it is often mistaken by planters for a seedling. On account of its small size and tendency to overbear we do not recommend it f o r commercial planting; though it is a very fine, rich peach for home use. After Elberta, September 1 st to 12 th.

\section{Chinese Cling--} Large, globeshaped, creamy white, with red cheek; flesh white, red at the stone. A cling noted for quality; none better. September 1 st to 10 th.

S t u m p t h e W o r ld - Large, almost round, Hottes Elberta white with slight red cheek, very sweet and rich. One of the best white freestones. Ripens in this locality September 1st to 15 th.

Mathews Beauty-A large. yellow peach with red blush, ripening about two weeks after Elberta. Very prolific and highly prized in Colorado where it is largely planted for commercial 'variety. Brings premium price on account of quality. New here.

Bokara No. 3-L a r ge, slightly oblong, yellow with brownish red cheek; flesh deep yellow, small pit, bears young. Tree very hardy. Ripens in September.

Wonderful--Large yellow freestone, fruit red at the stone. Very desirable for late season. September 10 th to 20 th.

Orange Cling-An exceedingly large yellow cling sugary with a distinct delicious flavor of its own. Bears regularly and abundantly. It is very highly prized as a commercial variety. Desirable season, ripening just after Elberta or about September 15 th.

Salway--Large, oblong, resembles both Picquett's Late and Smock, but better than e i the r; yellow with red cheek; fruit red at stone; very productive. September $20 \mathrm{th}$ to October 5 th.

\section{Phillip's Cling--} Large, flat pure yellow peach; firm being so solid as to almost resemble a partly ripened plum clear to the pit, which is very small thus making it a very desirable variety for canning and preserving, a 1 s o

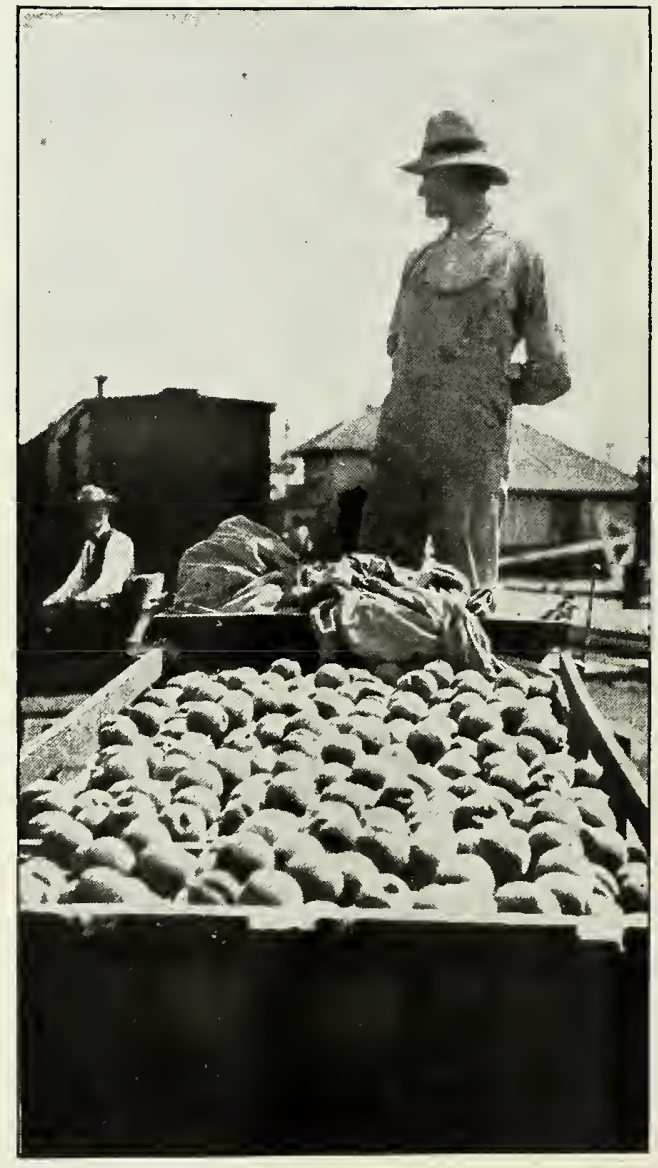

Load of Elbertas from which was packed the box sent to Mrs. President Taft. Grown by J. E. Morford, Palisade, Colo. Every Peach a queen, from four year old Winfield Nursery Trees of Quality.

NOTE:--This photo was taken before the fruit was graded, just as it averaged from the tree. 
for long shipments on account of its firmness. Season last of September, makes it a very desirable coinmercial peach on account of other varieties being gone at this season.

Heath Cling-The old white cling, ripening late in the fall, very large and fine. September 20th to October 5th.

Blood or Indian Cling-Large, dark red; flesh red to stone with an abundance of red juice; very hardy and productive. Last of September to October 10th

Henrietta Cling--Very large, yellow cling, with dull red cheek; flesh yellow, red at pit. One of the best yellow clings, prolific and regular; ripens in October.

\section{NEW VARIETIES OF PEACH}

As explained in the foregoing paragraph "New Fru-itis" the growing of new varieties is very much overdone. The following however represent the highest quality of a large number of new varieties. In obtaining these, many others have been tried and discarded. We shall add from time to time such new varieties as are of sufficient merit.

Dr. Burton-Very similar to Mamie Ross in vigor, certainty and abundance of bearing; has large flowers. Much superior to Mamie Ross and ripens about one week earlier. It is a perefct free stone, of rather larger size than Mamie Ross, of same shape, with smaller seed, much firmer and more color, and quality of the finest; the best and handsomest peach of its season.

Munson's Cling (Elberta Cling)-A selected seedling of Elberta, among hundreds grown from select seed. Equally as large as Elberta, more spherical, with a short beak. Firm, yellow flesh of the finest quality. Surface mostly covered with bright red, very handsome. An immensely superior quality to Chilow. Ripens with Elberta.

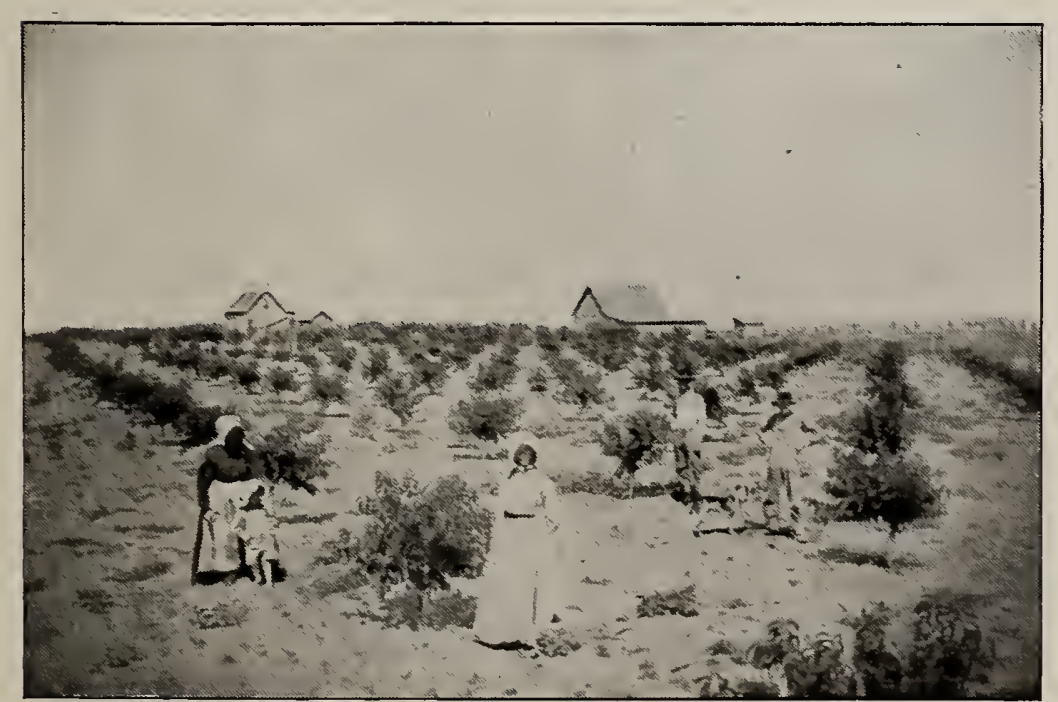

300 Perfect Peach Trees. Orchard of R. H. Hinton, Hydro, Oklahoma. One Year Growth of Winfield Trees of Quality,

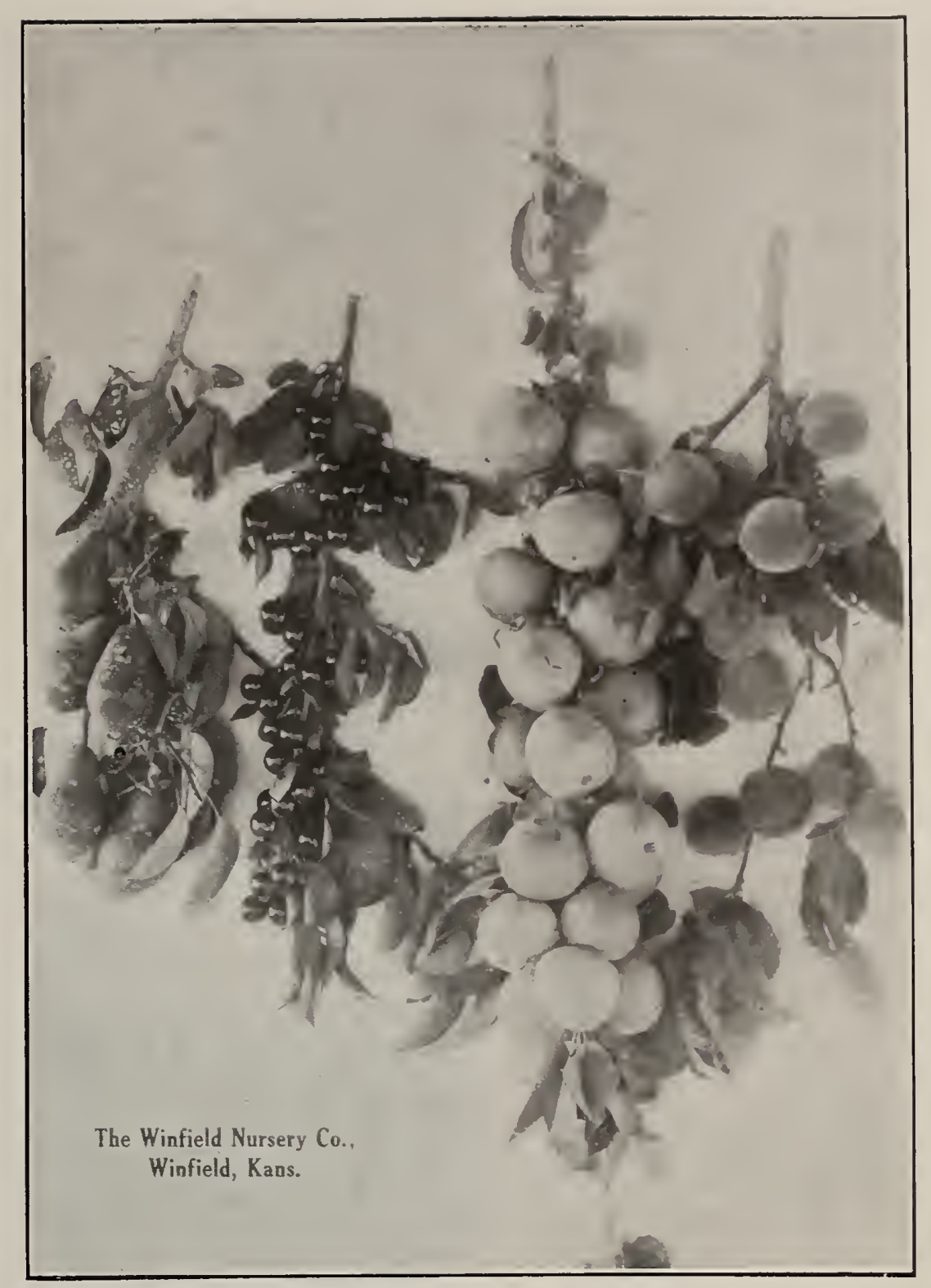

Fruit Grown From Trees of Quality

Munson's Free--Selected variety among several hundred Elberta seedlings grown from selected seed. The fruit is larger than Elberta; more highly colored, more oblong and of better quality; flesh yellow. More prolific and hardy in bearing. Ripens about a week later than Elberta. Very firm; fine for shipping.

Rex-A seedling of Elberta, ripening about a month later. The variety in size, color of skin, and flesh is very much like Elberta.

\section{The Winfield Nursery,}

Winfield, Kansas.

\section{Gentlemen:-}

I had good luck with my peach trees. I am sending you a picture of my orchard. I purchased of you last year and didn't get to set them until March 1909 and this is a picture of it. Out of 300 trees I lost three and the gophers killed these. I have the prettiest orchard I ever saw. If you doubt my word, I refer you to H. K. Dougherty with whom some of you are zcquainted.

Yours respectfully, 
Pears bring the highest market price of all the fruits. The Keiffer variety is especially hardy, productive and valuable for commercial planting in the Southwest.

D. D. Shane, of Winfield, Kansas, writes:

"January 20, 1905.

I sold 50 bushels of Keiffer pears last year from eight trees, and received from $\$ 1.00$ to $\$ 1.50$ per bushel for them."
Palisade, Colo. Feb. 11, 1909.

The Winfield Nursery Co., Gentlemen:-

Winfield, Kansas.

For the season of 1908 I marketed from 62 ten year old Bartlett pear trees 473 boxes or bushels of fancy pears and 14 boxes or bushels of choice pears weighing 50 pounds to the box. The gross amount of money received for this crop was $\$ 5.77 .19$ or $\$ 9.31$ per tree. Yours truly,

J. M. MENTZER.

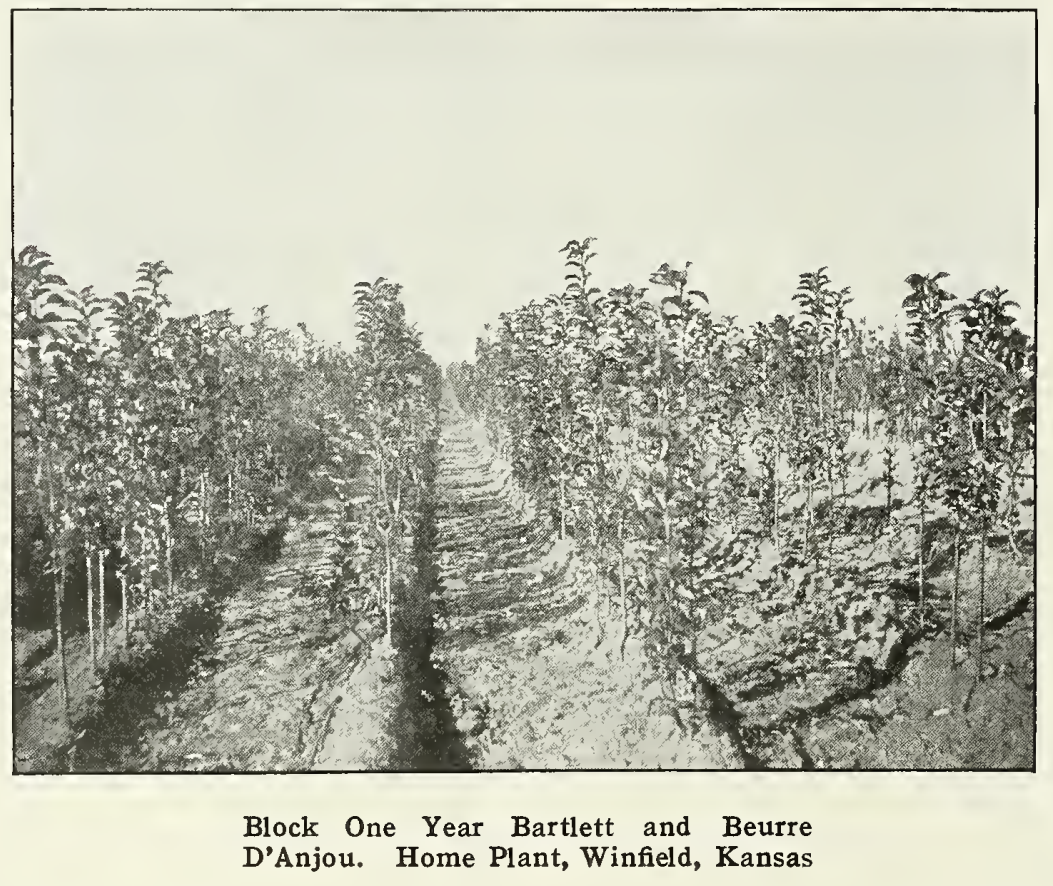

Clapp's Favorite-A fine juicy, rich, summer pear; pale y.llow, with tinges of red. Fruit large; tree prolific. Ripens last of July. S.

Bartlet--Large bell shaped, pale yellow with red cheek, fruit fine grained, juicy and rich, well known and stands at the head of pears for quality, trees inclined to blight in this locality. Highly recommended for planting in New Mexico and western irrigation districts where it is a great success as a commercial variety. Fruit always demands a fancy price on the market. August 1st to 15th. S.

In western irrigation valleys where the Bartlett and Beurre d'Anjou pears succeed, they should be planted heavily. The fact of being a failure in eastern belts always insures a big price for the fancy varieties.
To Whom Concerned:

This is to certify that the above report on pears from J. M. Mentzer is correct and can be verified by the examination of his account on our books.

Yours truly,

THE.PEACH GROWERS ASSOCITION. G. B. Forsman, Manager.

Mr. Joe Moncrief,

Dear Sir:-

In regard to your request for statement regarding the proceeds of a Palisade pear orchard, will say I hereby submit the facts and figures on 44 Bartlett Pears for the year 1907, trees 10 years old and all the Bartlett Pears on my ranch, as had I have kept just 25 of the heaveist bearers would likely have averaged $\$ 3.00$ higher per tree. 
I shipped through Grand Junction Association at Palisade 318 Boxes and $3 \frac{1}{2}$ boxes for which I received \$773.54, seven hundred seventy three dollars and fifty four cents. I shipped to fairs and to relatives 10 boxes worth $\$ 23.00$ or total of $\$ 797.04$. $\$ 797.04$ worth of fruit from 44 ten-year old Bartlett trees, planted $16 \frac{1}{2}$ feet each way or one square rod to tree, paying $\$ 18.11$ per tree, saying nothing of Pears canned or eaten at home.

\section{J. E. MORFORD.}

Subscribed and sworn to before me this 24 th day of February, A. D., 1909.

Roswell H. Banroft, (Sea1) Notary Public.

My commission expires January 25, 1913.

Seckel-Often called the little sugar pear; small yellow overspread with a brownish shade; flesh juicy, rich, sweet and spicy. Tree thrifty, large spreading growth. often rese m bling a spreading apple tree; bears regularly and very heavy crops; seldom ever blights. August 15 th to September 25th. D. and S.

\section{Louise Bonne of Jersey} -Large, 1 on g pear shaped fruit, tapering slightly to the base; smooth skin; pale yellowish green with red cheek; flesh yellowish white, very juicy, rich and sweet. A very desirable summer fruit. Succeeds best as dwarf, which bears very young and trees are loaded down with fruit. Season following Bartlett in September. D.

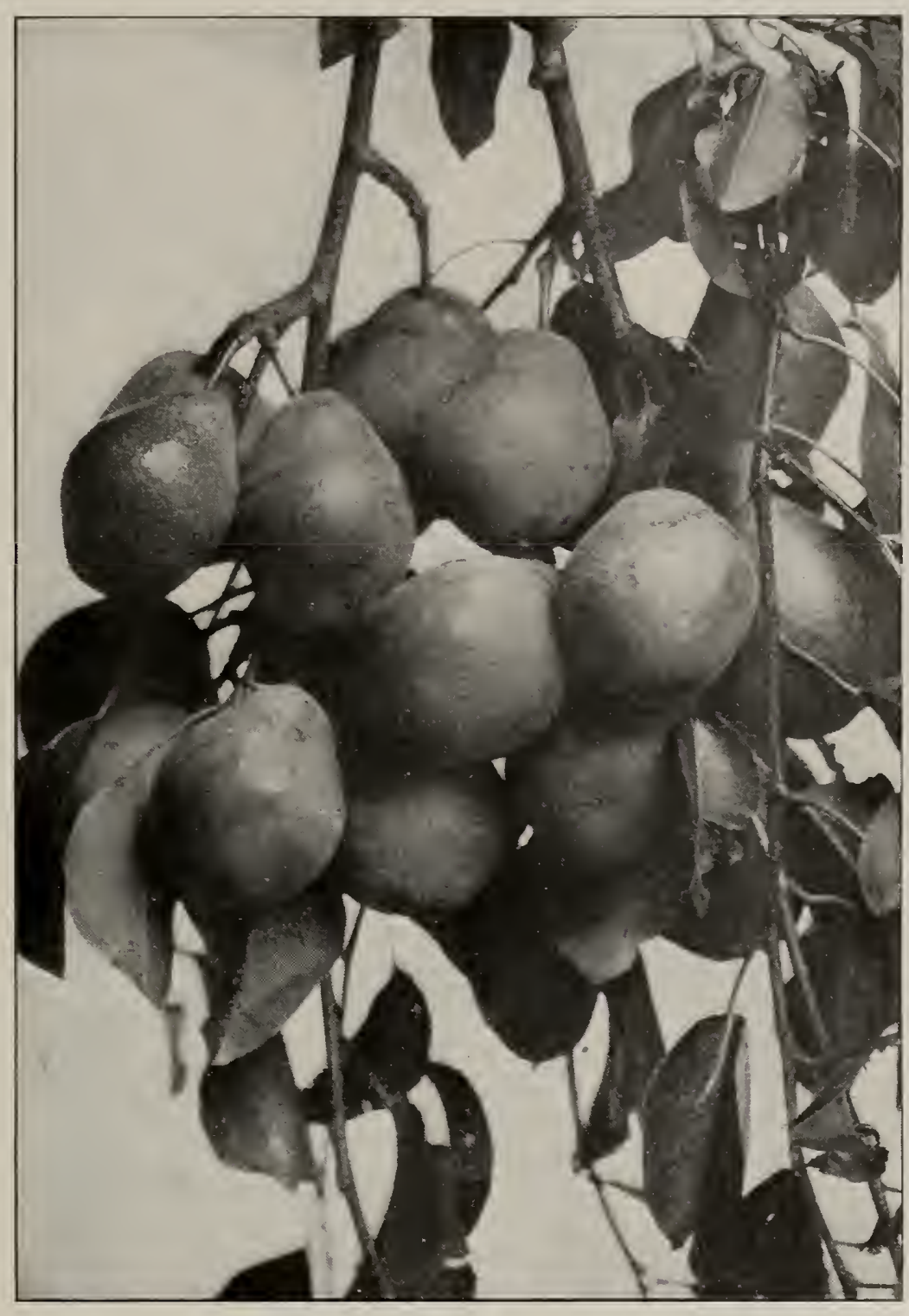

Branch of Keiffer Pear from Orchard of G. W. Brown so hardy in this district as the Keiffer type in resisting blight. September to December. D and S.

Duchess (D'Angouleme) - A very large showy pear often weighing one pound each; oblong, largest at base; greenish yellow, rough uneven surface. The most profitable dwarf pear in this section. Trees rarely ever blight; are always loaded down with fruit. Little trees in nursery row often hang full of fruit. Succeeds best as dwarf. September to October. D
Garber-Medium size yellow, well colored with red. Fair market variety. Tree thrifty and bears young. Almost blight-proof. Not equal to Keiffer for profit. Last of September and 1st of October. $\mathrm{S}$.

Buerre d' Anjou-Very large, greenish yellow, slightly tinged with russet, very dull red cheek only when exposed to the sun; irregular pear shape, being largest at base and one side of pear slightly longer; flesh yellowish white, fine grained sweet and rich. On account of high quality it always commands a fancy price and is especially noted for its commercial value in New Mexico, Colorado and other western irrigation districts where it is a great success. Not
Branch of Keiffer Pear from orchard of G. WW. Brown north of Winfield, Kansas. On an 18 inch stem there were twenty-three well developed Pears when stem was plucked from tree. Four dropped off on account of weight in handling and the other nineteen appear in this photograph. From an orchard of sixty-five trees Mr. Brown expects to market some four hundred bushels of these fine Keiffer Pears and this orchard while on good land has not been given any special care, not having been sprayed at all. If under these conditions an orchard will produce such a crop, on the very best of soil and in the best fruit section why would not Keiffer Pear be one of the best money making commercial varieties of fruit for the orchardist to plant. It undoubtedly is equal if not superior so far as profit is concerned to any other class of fruit that can be set out.

Keiffer - Tree vigorous, beautiful, upright grower, bears young and heavy. Almost exempt from blight. Fruit large, oblong, large in center; green when picked, turning to yellow when ripe. Quality fair. Fruit must be gathered and laid away to ripen before good. The best commercial variety. October to November.

Winfield, Kansas, Dec. 29, 1908.

Twenty six years ago I set out 60 Keiffer Pears, for which I paid $\$ 1.00$ per tree. These have borne fruit since they were three years old anually, with the exception of the year 1907, the only year that the fruit was killed by frost to this time, I have never sold the fruit for less than \$1 per bushel. There are now 49 trees, living, which are hardy and solid and I gathered 


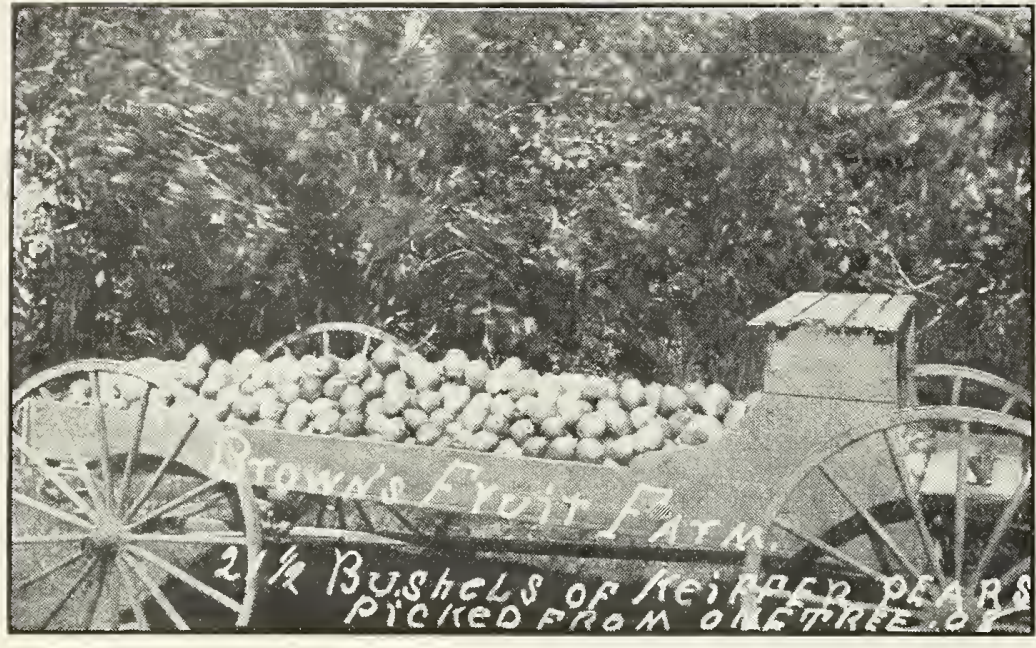

this year and sold 400 bushels of picked pears, ranging in price from $\$ 1$ to $\$ 1.50$ per bushel, the average price being about $\$ 1.25$ per bushel. Had I gone in debt and borrowed the money to have planted twenty acres when I planted this orchard, it would be worth $\$ 20,000$ to me today. Furthermore if my neighbors would co-operate with $m e$ in planting enough trees to insure us the privilege of shipping in car load lots, we could realize a much better price for the fruit. I planted a young orchard this spring of this variety and if others will co-operate with me, I will be glad to put out a larger acreage in order to secure enough for a Fruit Association. My farm is located two miles north of Winfield and my fruit records will verify my statements.

\section{C. BROWN.}

Editor of Farm and Ranch, of Winfield Kansas, finds by investigation among old fruit growers: Keiffer pears have borne annually in this section for the past twenty years; are prolific and not killed by blight. D. D. Shane, of Winfield, Kansas, sold in 1906, one hundred bushels from ten trees.

Mrs. Lundy of East Ninth avenue, Winfield Kansas, has a tree of Keiffer Pears that has never yielded less than twelve bushels a year for the past ten years and an average of fifteen bushels a year. In 1903, it produced $21 \frac{1}{2}$ bushels, in $1904,17 \frac{1}{2}$ bushels. Fruit from this tree never sold for less than $\$ 1.00$ per bushel.

Comice-Large, greenish-yellow, with slight crimson shade where exposed to sun. Quality extra. A late keeper very much prized in western irrigation belts. C. E. Whistler of Medford, Oregon, realized $\$ 4$ to $\$ 5$ per box from this variety?

\section{Q UINCE}

Orange-Very large; golden yellow; fine for jelly and preserving. Sells readily for $\$ 3.00$ per bushel.

Missouri Mammoth-A new variety, highly recommended, but not fruiting here.
Vandeman-Worthless here on account of blight. "Vandeman Quince all died with blight, only procured two quinces from. four trees before they were destroyed with blight."-M. C. Brown, Cowley County, Kansas.

\section{CHERRIES}

Cherries must not be planted in wet ground. Observe this rule and Winfield Nursery Cherries will prove very hardy. Stands more drouth than most any other fruit.

We shall continue to bud cherry on Mahaleb stock. Though it costs much more to produce a tree on this stock, it is the only cherry tree that gives entire satisfaction, as trees propagated in any other way sprout from the roots. No fruit in this section has fewer enemies or gives better results than the family of sour cherries. Sweet cherries are a great success in western irrigation districts.

Dyehouse-One week earlier than Early Richmond, which the fruit resembles, except that it is a little darker color; quality good. Trees not so hardy or prolific as Early Richmond. Last of May.

Early Richmond (EARLY MAY)-Our best early cherry. Fruit fair size; bright red. Tree vigorous, round top; bears young regularly and is prolific. First of June.

May Duke--Large dark red, flesh subacid, juicy and rich. Characteristics of the Duke family are a hardy tree and upright growth. It is very profitable in irrigation belts of Colorado, Utah and Idaho. Ripens May 20th to June 5th. This variety should be followed by the Royal Duke and late Duke. These three are the very best for commercial purposes.

Royal Duke--Very large round cherry. One of the very best of the Duke family. Shaped distinctly flattened; skin very dark red; flesh reddish juicy and rich; Tree very beautiful upright grower with heavy foliage making it an especially beautiful tree for yard or street planting. Very highly esteemed as a commercial variety in the western irrigation districts. June 5 th to 15 th.

Note:- One tree of this variety in Palisade, Colorado, is reported to have yielded $\$ 35.00$ worth of fruit in 1907, and single acres of this variety, in this section have yielded as high as $\$ 1,200$ in one season. The buds of our trees were taken from bearing trees in the Colorádo district. Season June following Early Richmond.

Montmorency (ORDINARE) - This is the genuine Montmorency of great merit, heavy annual crops of beautiful large fruit. Tree upright and spreading, vigorous, stands drouth well, bears regularly and is 
very prolific. Fruit round and flat; a rich bright red, flavor resembles Early Richmond but fruit is more solid. Has not failed with us in the past six years. Ripens two weeks after Early Richmond. Sometimes confused with Large Montmorency, a much inferior cherry. June 14 th to 20 th.

Late Duke-This variety resembles the Royal Duke, ripening at a later date. One of the very best if not in the lead in irrigation belts. Also a winner in Eastern states. Very much prized in vicinity of Caldwell, Idaho. Not widely known but cannot be recommended too highly. Free, hardy, upright grower, limbs stiff and stocky. Bears large crops annually.

Napoleon Bigarreau (Royal ANN)-A most beautiful cherry of largest size; oblong and slightly heart shaped, yellow background overspread with bright red and covered with dots of deeper red. Flesh brittle, solid, sweet and rich. Tree very hardy. One of the favorites for western commercial growers.
In the language of one given a sample of this large cherry: "It offers some resistance when you bite into it."

Black Tartarian-Large size, dark red, almost black, irregular in shape. Flesh purplish color, sweet and juicy. Especially prized as a Western Variety.

Bing-This is one of the largest sweet cherries, fruit almost comparing to small size plums. Large, dark red, sweet, juicy; quality superb. Hangs on tree late. Fine shipping variety, especially recommended for western Irrigation Belts. July.

English Morello-Large dark red almost black when ripe; flesh purple red, very rich, sour. Tree bears young, regularly. It is always very prolific. Fruit always commands good market price. Tree slow growth, small for their age and inclined to be short lived, perhaps on account of very heavy bearing. First of July.

Imp. Rocky Mountain Dwarf Cherry-A sour worthless fruit, unfit for any use, does not resemble cherry. A perfect humbug.

\section{PLUMS}

No fruit is more at home in this section than the plum. Where not destroyed by prairie fire, they are often found growing wild. To have not planted plum trees in the last few years means to have been without plums in the true sense of the word. For the change from the stage-coach to the modern luxurious parlor car is not greater than the advancement in the fruit of the plums, owing to the horticulturist's careful work.

Instead of a small, sour fruit, you can now grow in two years after planting the tree, large, rich, luscious fruit, as mild as the peach, as rich as honey, yet with a spicy twang that appeals to the taste as does no other fruit.

Milton-Fair size, roundish, oblong, beautiful bright crimson red with white dots. A cross of Wild Goose; quality far better. Tree vigorous. A new variety, but is inclined to be very hardy and prolific. June 20th.

Red June-Earliest Japan plum; bright deep red with bluish bloom; good size, pointed; flesh yellow, sweet and rich; very solid for early fruit. Tree vigorous and very prolific. Is giving satisfaction in Colorado. June 25th.

Ogon-A yellow freestone; good size. roundish, oblong; flesh yellow, firm, and fairly rich, not juicy. A fine freestone for canning. The hardiest yellow Japan plum. Latter part of June.

Wild Goose-A well known old variety; fair size, nice looking, quality poor; rots in twenty-four hours after picking, making it a complete failure for market. Bears abundantly, but not regularly. July 1 st.
Abundance-Fruit medium to large; dull red color, greenish yellow flesh, melting sweet. A Japan plum similar in quality to the Burbank. Tree is upright grower, bears young and regularly, but not hardy. Tree inclined to scald badly in south and southwest and winter kill in colder climates, making it usually a short lived tree on this account often causing the heavy crops of fruit to be injured by rot. On account of hardiness of other vareties they should be planted more extensively than this one. Season July 1 st.

Marianna-A beautiful round headed tree with thick foliage. Almost sure to never bear. Have discarded it.

Burbank-Fruit large roundish, conical form with a blunt point; ground color rich yellow colored with

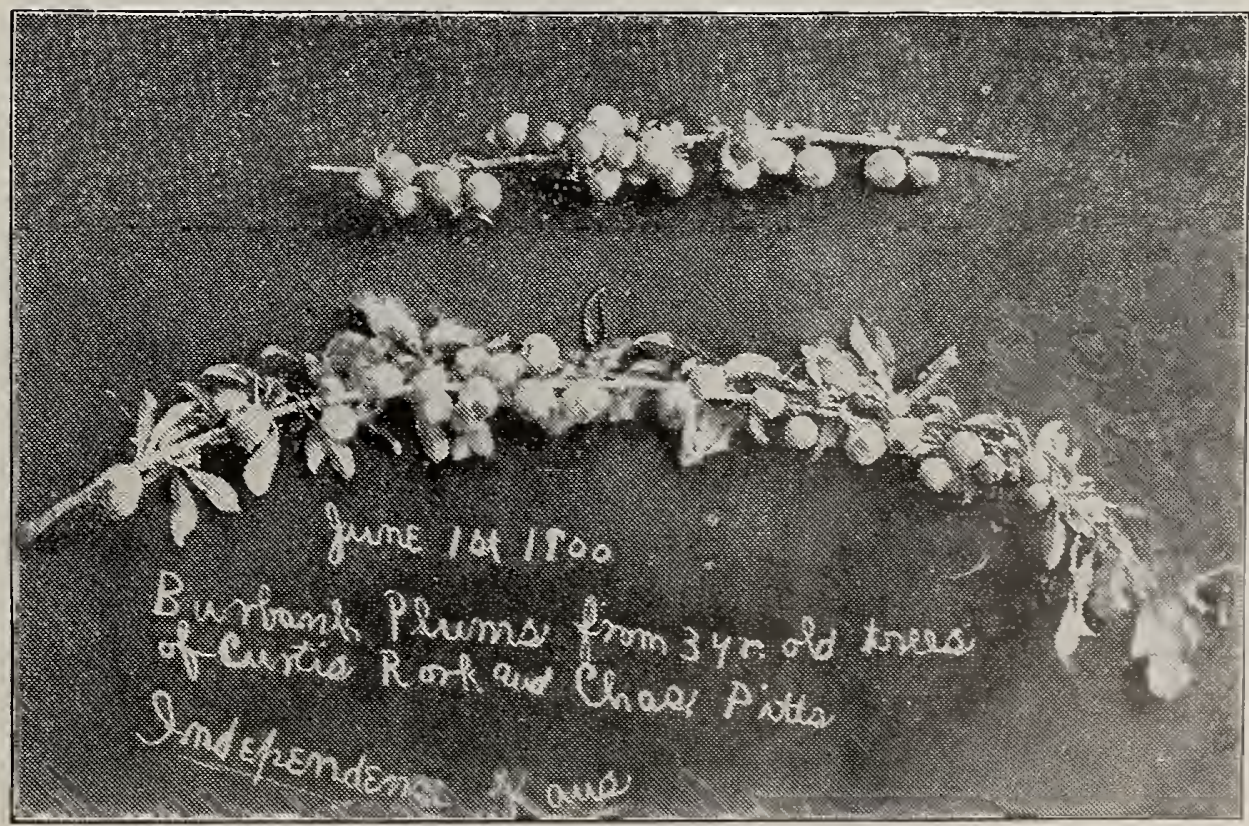


bright red, except usually one yellow spot; fruit solid making it one of the greatest market varieties in the Plum family. Tree vigorous and hardy; sprawling grower almost drooping; seemed shaped by nature to hold its excessive load of fruit; bears young and regularly; could not be more prolific; three-fourths of fruit should always be thinned from tree. This Plum is one of the best Japan family for this section and heads all other varieties of Plum in desirability for both home use and market.

Satsuma-Large; flesh blood red. Bears young and very prolific in Oklahoma, Colorado and New Mexico. Brings highest price of all plums, very prolific in irrigated sections. Tree sprawling, thrifty grower. One of the Japan family.

Hale-Medium large, flesh yellow, juicy and sweet; spicy rich flavor. A new promising variety. Not thoroughly tested here yet. Ripens July 20 th.

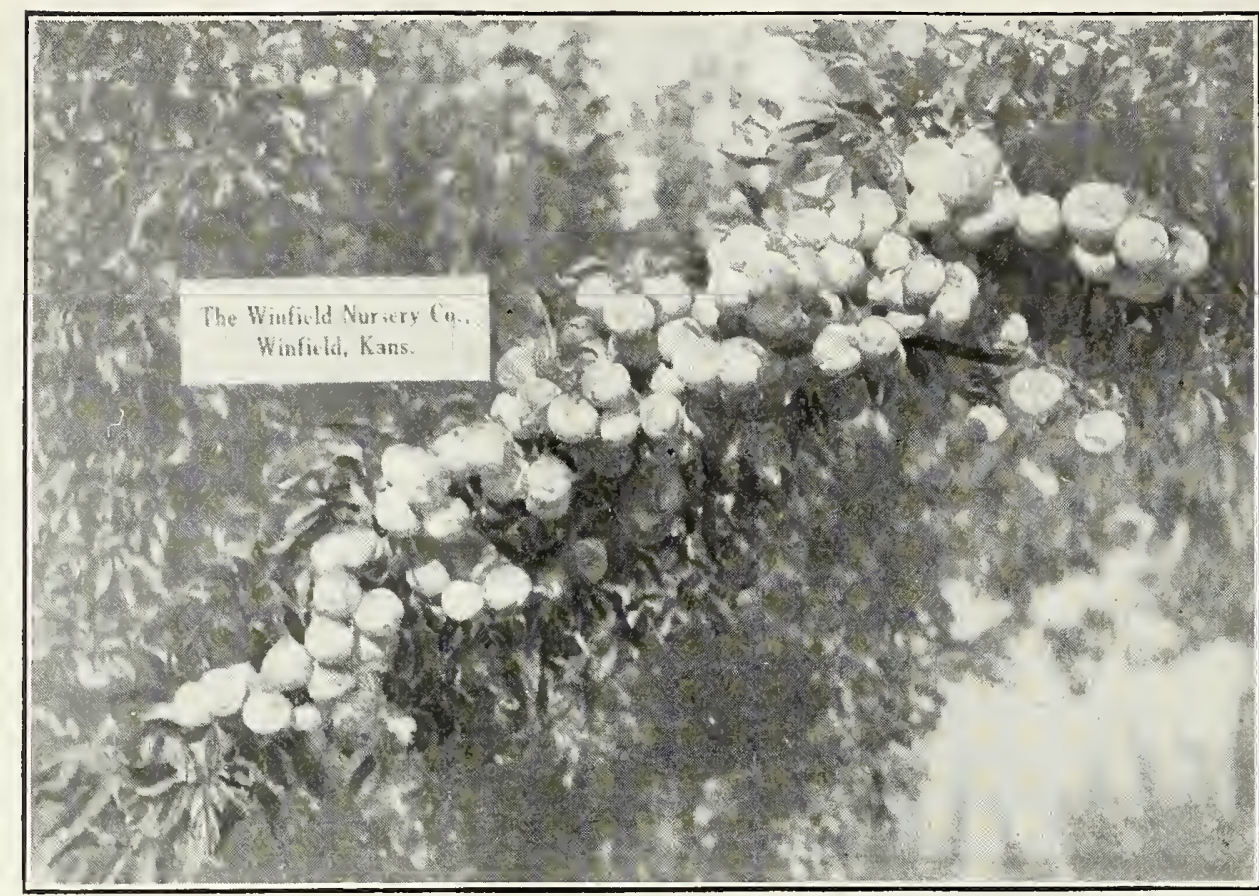

SATSUMA PLUM
Ringwood, Dec. 9, 1909.

To The Winfield Nurseries:

Gentlemen:--

I received trees all $\mathrm{O}$. $\mathrm{K}$. They are the nicest trees I ever saw shipped froni a nursery.

Yours truly,

\section{V.H. BEN'TLEY}

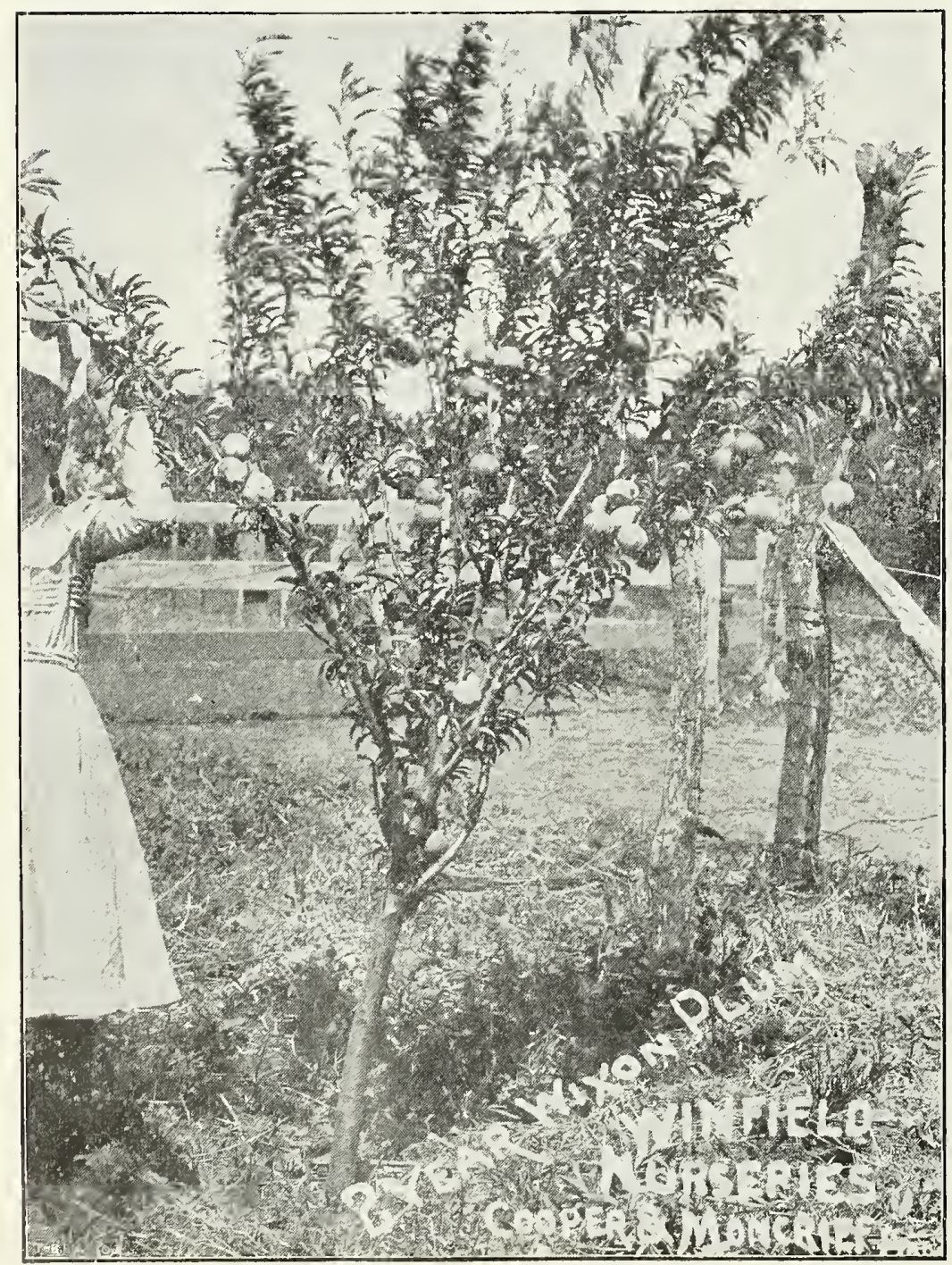

Wickson-Fruit very large, measured seven inches in circumference gathered from two-year old tree; deep red color; flesh firm. One of the very best late Japan Plums and very desirable on account of ripening a month later than Burbank. Tree a thrifty upright grower, very hardy; bears young, heavy and regularly. August.

Little Blue Damson-Small dark blue'plum of fine quality. Tree slow coming into bearing, but very hardy; bears regularly and profusely in about five years after planting. September.

Desota-Medium size; almost round; dark red, with small round white dots; flesh orange yellow, juicy, quality good; very sour when cooked. The best native variety we know of. Tree hardy but rather slow and ugly grower; blooms with late apples so always bears a heavy crop. August 5th.

Green Gage-Small, round, slightly oblong; yellowish green, juicy and sugary sweet, almost a freestone. An old variety very highly esteemed for its quality; very prolific, but slow about coming into bearing. August first.

German Prune-Purple or blue plum; oblong oval in shape with crease in one side of fruit; flesh firm, light green, separates partly from the stone making it desirable for drying. Very prolific, but like other plums of the European type slow about coming into bearing. September.

\section{Palisade, Colorado, Dec. 6, 1909.}

The Winfield Nursery Co.

Winfield. Kansas,

Gentlemen:--

I have bought trees of several nurseries and can say your trees are better than any trees I have ever bought and have better root and top systems than any trees I ever saw planted, along with yours and I have planted trees for five years.

GEO. W. WINN. 


\section{APRICOTS}

The Apricot is the hardiest tree we have in the nursery. Will grow vigorously on new prairie land or on rocky points, where all other trees fail.

Early Golden-Small, golden yellow, oval shaped, freestone; very prolific when it bears, but often fails on account of spring frosts. Middle of June.

Royal-Medium size, roundish oval, dull yellow, flesh light yellow, sweet and highly flavored; freestone. Last of June.

Moorpark-Large, almost round, golden yellow, with red cheek; freestone, juicy and rich. We recommend this as one of our best. First of July.

Superb-A fine seedling originated at Lawrence, Kansas. Fruit large; rich yellow flesh; quality very fine. After Moorpark.

Alexis-One of the Russian varieties. Small size; round, pale yellow with red blush. Trees prolific and hardy. Not so desirable as the larger varieties. July.

Blanche-Surpasses anything in apricots we have yet seen. The original tree is growing on the farm of William Schwantes, where it has been fruiting six years. A chance seedling from apricots brought from Russia to Newton, Kansas. Tree thriftier and hardier than any other variety; bears full crop when others fail. Fruit excels in size and quality, large as early peaches; light yellow. Flesh yellow, rich and sweet, clear of woody fiber sometimes found in other apricots. Fully believe it excels all other varieties in regular bearing, size and quality. we offer it for sale unde $r$ the name of Blanche, which name is given in honor of the originator's daughter.

Montrose, Colo. Jan. 17, 1910.

The Winfield Nursery Co.,

Winfield, Kansas.

Dear Sirs:--

Please send me your catalogue for 1910. I have ten acres of your trees set out two years ago and I feel proud of them, they are the best of any two year old trees I have ever seen. They cost me $15 \mathrm{c}$ each and my neighbor has an orchard of the same age that cost him $25 \mathrm{c}$ each, and I have been told often that my trees look the best, so it is not my own judgment.

What good commercial variety of Apples would you recommend as good fertilizers to set out as fillers with Jonathan and Gano?
R. R. 1
(Signed)
R. COLOED.

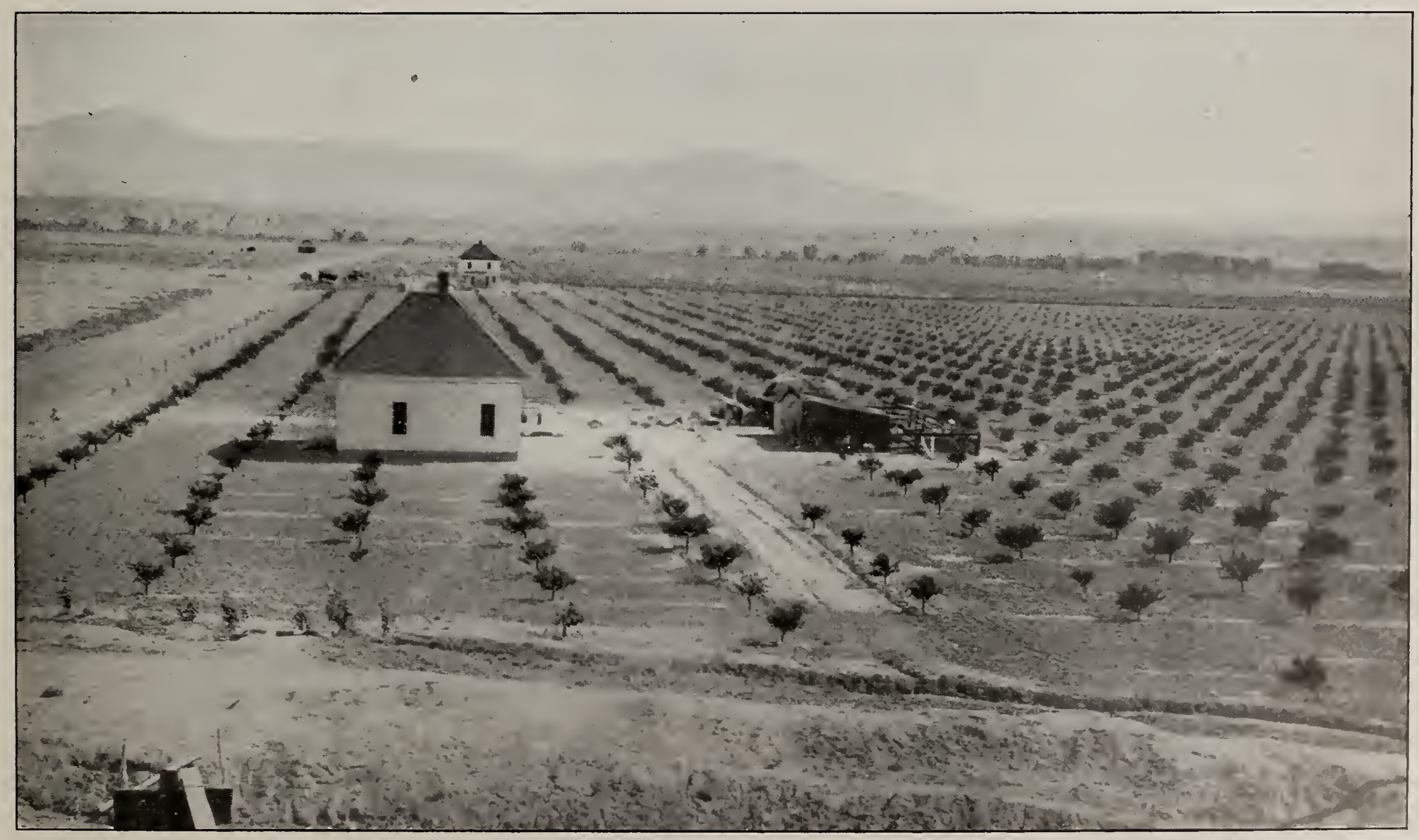

Birds-Eye View of Our Own Orchard at Green River, Utah, Showing Ranch House and Home of Foreman

Our own Orchards at Palisade, Colo. and Green River, Utah, in the irrigated lands divided into ten acre tracts will make homes to support 50 families in luxury. In 1910 a portion of this land will be blocked out and sold but a large acreage will be reserved from which we will market fancy Quality fruit. 


\section{GRAPES}

No fruit succeeds better in the West. It is free from mildew and disease that bothers in the east.

Campbell's Early-Bunch and berry better than average; black, fine quality, keeps long after ripening, Ripens with Moore's Early. New, but very popular.

Moore's Early-Bunch medium, compact, berry large, black, quality good. Bears regularly but not so heavily as Worden. Good market grape on account of its earliness. Last of July.

Worden--The best black grape we have found. Bunch large, compact; berry large, black, thin skin, fine flavor, rich and very sweet. Vine perfectly hardy, bears heavily and is very prolific. Fruit sells readily at double Concord price.

Dracut Amber-A small bunch, amber color, good for jelly, poor for market. August 15th.

Concord--The old well known black grape; good flavor, quality fair. Vine hardy, bears regularly and heavy crops. August 22nd.

Niagara-Large, long bunches, very fine white grape, quality first-class, hardy, bears regularly and heavy crops. Comes in just after Concord. Have discarded Pockington and Elvira, as Niagara is far better than either.

Agawam (Rogers No. 51)-A very large grape of fine flavor, sweet and rich. Vine hardy and vigorous grower; prolific. Color dark red. August 25th.

Goethe (Rogers No. 1)-A very large greenish white grape, almost covered with red when fully ripe; berry oblong, tender, rich and very sweet. We have found no grape of better quality. Very hardy, prolific and regular. Ripens after Concord is gone, commanding good price.

\section{FOREIGN GRAPES}

These grapes are suitable for planting in California and the irrigation belts of New Mexico, Colorado and other western states, where the vines produce from four to five hundred dollars worth of grapes per acre annually, but have to be cut back every fall and covered with dirt to protect them from winter freezes and then uncovered early in the spring. These varieties command fancy prices and sell for ten cents to twenty cents per pound, when ordinary grapes are selling at two cents per pound.

Thompson's Seedless-Vine perfectly hardy, rapid grower, bunches large, compact, berries greenish yellow, medium size, thin skin, seedless, making it a most desirable grape for eating. Flavor excellent, sweet and delicious. Aug. 15 to Sept. 15.

Flame Tokay--Exceedingly large, compact bunches Single clusters often weigh from four to seven pounds each. Berries as large as small plums; skin thick, pale red; flesh firm and sweet. Very desirable variety for long shipments. September 15th to October 1st.

Black Cornichon-Bunches long and loose, not so large as Flame Tokay. Berries oval, long, tapering at both ends; skin thick and dark; flesh firm and rich. This variety is especially desirable because of its firmness in handling for long shipments. Considered one of the best paying grapes for commercial planting. October 1 st to 15 th.

\section{BLACKBERRIES}

Not only one of the most luscious to the taste, but stands to the berry family in much the same relation as does the apple to the other tree fruits. Is in the greatest demand, regarding quantity, of any other berry, because of its being a standard in the house for canning and cullinary purposes. Regarding quality no fruit has been more neglected in the past by nursery men than blackberries. While some of our most eminent nurserymen have advanced the standard of other fruits, they often have been content to sell blackberries run down from patch plants, unfit for planting.

Depending on chance and cultivation, even then some great improvements have appeared in blackberries, and we have early berries fruiting a month earlier than the old natural season, late berries that Nature had provided with a heavy foliage to enable them to ripen their fruit in the southwest, and retain their juicy, rich qualities.

Time to Awaken to Nature's Laws. We have long realized Nature's laws in animal breeding, and have for our trouble the speedy race horse and the heavy draft horse, marking the two extremes, giving us that for which we have striven by observing Nature's laws. So well is this fact now admitted among the leading fancy breeders of stock and scientists of our country that three years ago The American Breeders Association was formed, of which we are proud of being a charter member, in which animal and plant breeders worked together in one association.

W. M. Hays, of Washington, D. C., Secretary of this Association, says of this movement: "Those who have attended the recent meetings of the organizations and particularly the last convention at Columbus have observed how the animal breeders, the plant breeders, and the students and scientific investigators are drawing closer together in attention, personal relations, and mutual appreciation of their related problems."

Gradual Deterioration in valuable varieties of blackberries show us the loss we have suffered by ignoring Nature's laws of plant life, and unless we remember 
that the hereditary instinct of plants is strong, and the natural tendency is to revert to the old small berries with a core and seed but not much fruit, and unless we constantly strive to improve the varieties we now have by a selection of the best and the elimination of those showing undesirable features, we shall lose what we have and only progress as in the past by new berries of desirability appearing by chance.

$\$ 5.00$ Per Thousand Blackberry Plants or $\$ 25.00$ Per Thousand and More. You can buy pateh plants of nurserymen, and even of some fruit growers, true to name, for $\$ 5.00$ per thousand, which would be on exactly the same principle as buying the poorest rundown runt from a Poland China herd of hogs, whose be of value for reproduction. It is not the maturing of the fruit pulp but the loss of sexual power in maturing the seed that ruins the plant and renders it unfit for breeding or propagating plants.

Patch Plants Illustrative. Every plantcr has noticed uneven berries, bushes with no fruit, small irregular, hard cored or poorly flavored berries, and at the same time individual plants bearing large rich berries in patches grown from patch plants. Or perhaps if you have not noticed this in patch plant berries, you have noticed the same condition obtaining in the eastern states where blackberries grew wild. You ean readily realize the difference if every plant in the patch bears its load of fruit of even, perfect berries of fine quality.

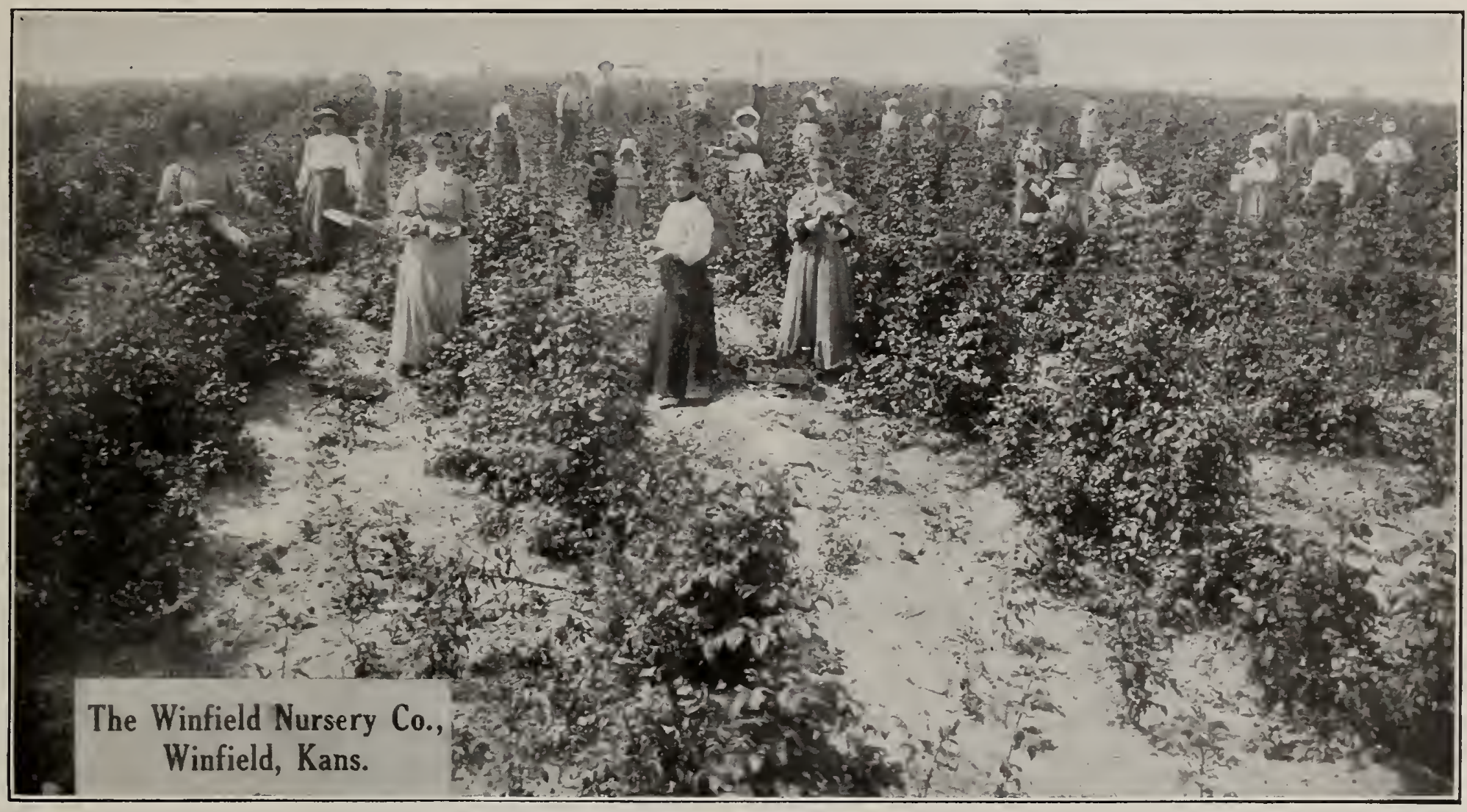

usefulness as a hog had been almost ruined by a system of in-breeding, neglect and ignoranee, or in other words not observing any of Nature's laws whatever, and disregarding improvements in breeding. While this no one would think of doing in the animal life, neither does any one who is making a success in upto-date berry growing. We charge $\$ 25.00$ and up per thousand for our plants and furnish hundreds of customers who dig up and burn their patch plants, or sometimes sell them to people who are not up-to-date in growing, fancy berries. We expect to see the time when we produce plants that justifies a fruit grower in paying us a fancy price for an individual plant, and yet give him value received. We shall never fill orders for patch plants, though we use them for testing purposes and afterwards dig them up and burn them.

Impotency. Well known in animal life, and guarded against in case of valuable animals by proper care; as reproduction of valuable characteristics cannot be brought about by overwork and over breeding, so like-wise in blackberries are these conditions true. Plants cannot raise heavy erops of fruit and at the same time throw up suckers of young plants that will
Propagating Blackberry Plants. Blackberries can not be budded or grafted, but can be propagated by root euttings from breeding patehes of healthy plants that have never been allowed to become impotent by bearing fruit. The very appearance of the plants themselves is sufficient to recommend them even before their value is shown in the fruiting. Notice cut of our plants showing the vigorous and healthy root system. Good breeding shows in plants just as it does in animals.

Renewing Breeding Patch With New Blood. This is done by letting plants in our test patch bear one erop of fruit, and have these scored by a competent judge in order to still further improve the old varieties. For example we quote from report of Professor Steiner, of the Botany Department of the Lutheran College of this place, in his scoring of Early Harrest berries with us last year: "Out of this large patch of fine berries, I have selected a number of the most promising plants, selecting them with regard to size and quality of berry, as well as hardiness of plant and abundance of fruit. The plants seleeted marked ' $\mathrm{X}$ ' are good and those marked ' $\mathrm{XX}$ ' are especially good. 


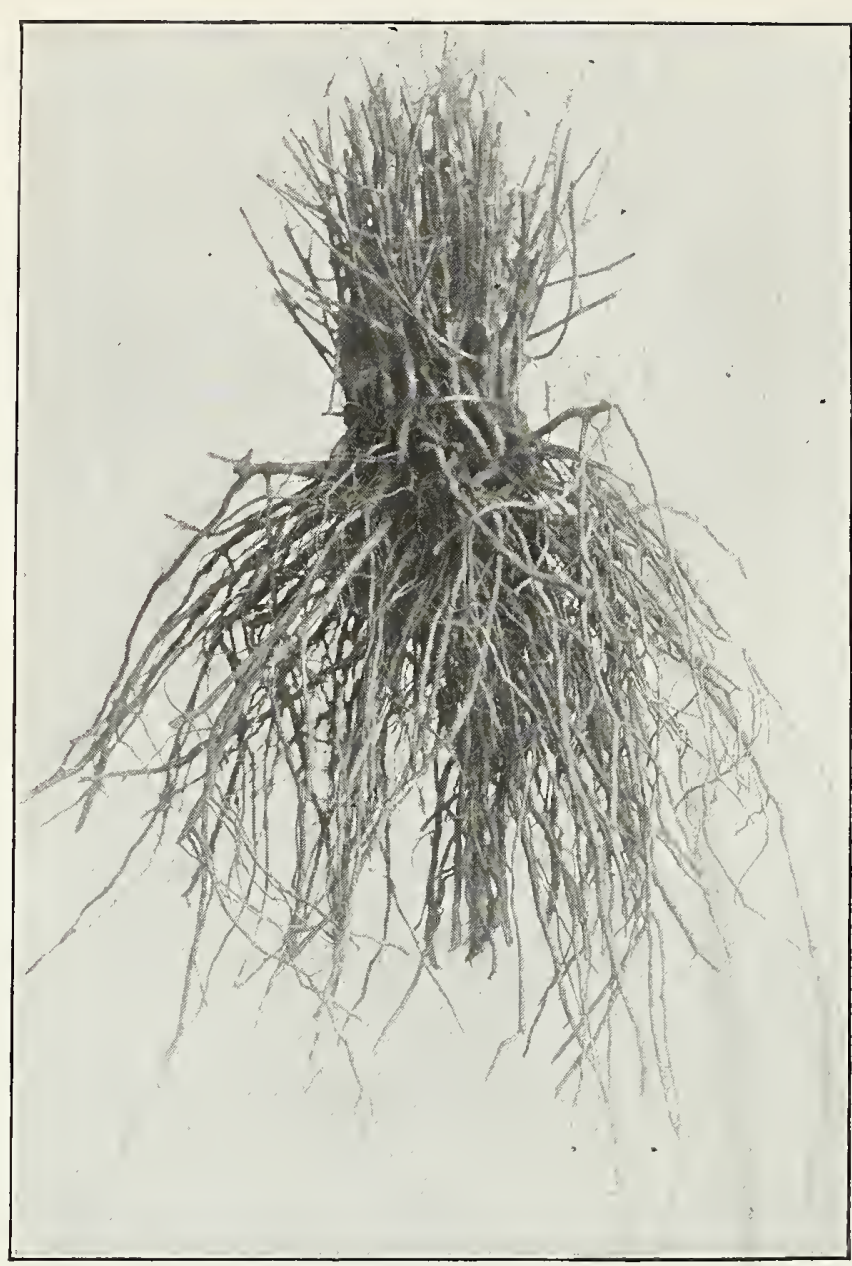

BLACKBERRY PLANTS

While this is an old variety, it is too reliable to discontinue, but by careful selection I believe may be brought to a much higher standard."

Remember that this berry on account of its wonderful prolific qualities, will run down and deteriorate in quality quicker than any other berry, when replanted from patch plants; for by referring back to Nature's laws again, in plant and animal life, it has become impotent.

The Winfield Nursery Company's Propagated Blackberry Plants please everywhere, but we only quote one letter for lack of space, photograph of whose berry patch we show the next year after planting.

\section{Cement. Oklahoma,}

Nov. 19, 1907

“* * * * In 1906 I received and planted 5,000 propagated blackberries from you. I got a perfect stand. I planted them in rows 7 feet apart, and 3 feet in the row, and a big per cent of the roots would lap in the row. In the spring of 1907 I sold about 1,500 gallons at an average price of about 25 cents. They were in excellent condition for a big crop in 1908, as bushes are much larger now than last year. I planted a part of them on ground underlayed with gypsum, about one-half acre, which are a complete loss, but it is altogether on account of the land. I don't believe I lost to exceed 2 per cent. I believe there were'bushes which bore as much as two gallons. I can heartily re- commend the Early Harvest. * * * * * * * * Yours truly,

$$
\text { J. C. BROWN." }
$$

Considering the fact that one-fourth of his plants were lost because of his ground, his patch paid him well the first year; patch plants are not expected to bear at all the first year, while our plants, as is above shown, pay for themselves many times over the first year alone.

Fine Blackberries Sell. Not only four or five times the quantity but also the quality enables growers of our fruit to get a premium price for their berries on the market and sell them readily while poor berries are a drag.

Early Harvest-Bush perfectly hardy, cane stiff, lipright, dwarfy habit, properly trimmed forms a tree shaped bush two to four feet high. Fruit good size, long, very small seeds, sweet and delicious. The only blackberry that has never failed with us in dry seasons. In productiveness a surprise to everyone; bushes weighted to the ground with fruit. Sprouts taken from bearing patches of Early Harvest are a worse failure than any other variety, and often bear small, inferior, hard berries. This is caused by the bearing plants having little vitality to impart to young plants after maturing a heavy crop of fruit. If you wish to keep a high standard of berries don't allow them to waste energy on useless sprouts. First of June to July.

Ward-Canes strong stalky three and one-half to five feet high, covered with very heavy dense foliage, which is protection to the fruit in this western country. Fruit the largest and richest berry we have ever grown in this section; about double the size of the Snyder. Beautiful black, glossy berry, rich in flavor; when cooked, juice almost resembles a syrup. Bushes are loaded down with fruit. Last of June.

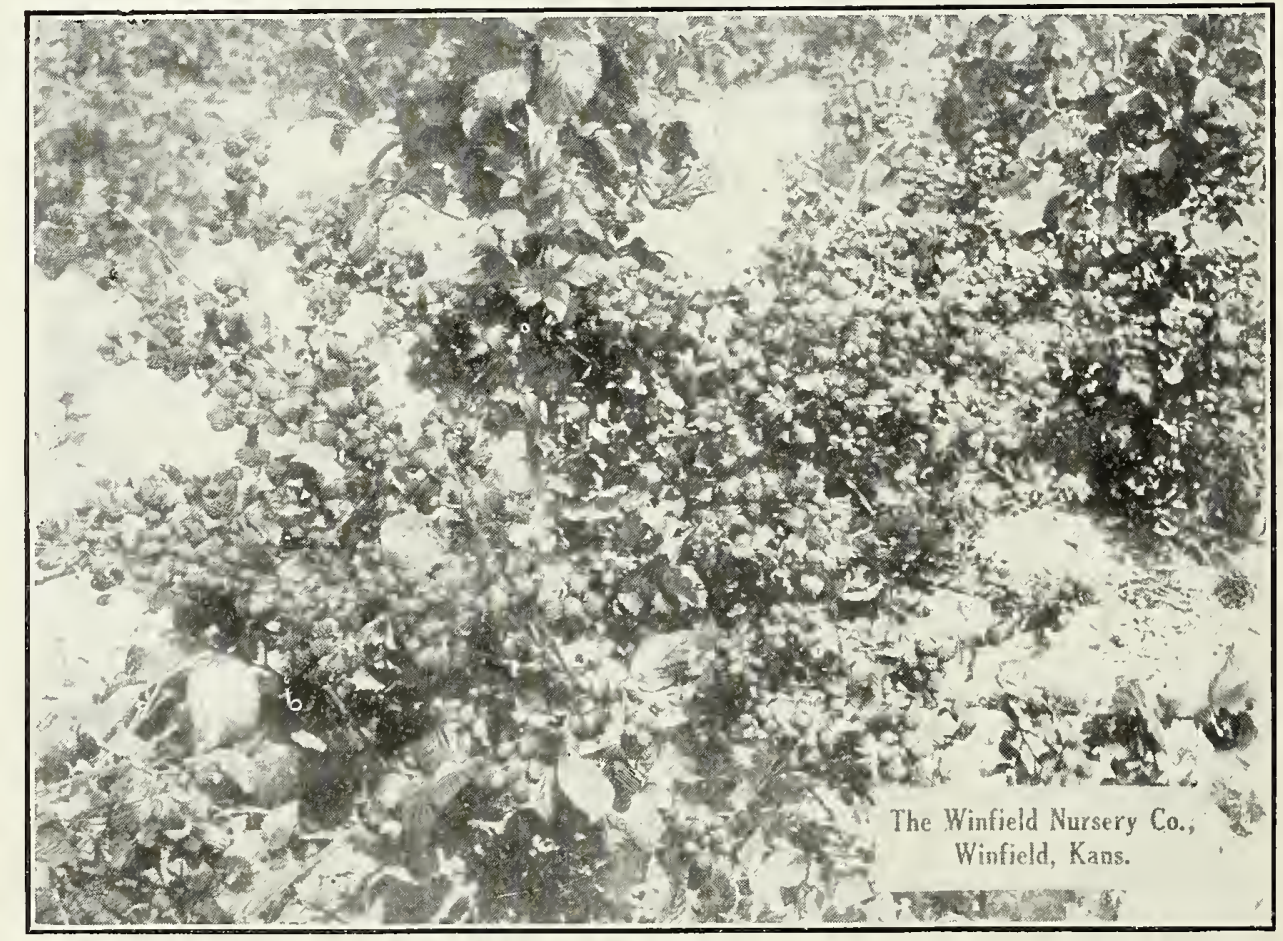

Bush of Improved Propagated Early Harvest Blackberry 
Note:-Prof. Steiner says of this berry, after having worked for two weeks among sixteen different varietics for the purpose of marking and scoring plants for breeding; "The Ward is the most promising variety in the experimental patch and merits your highest esteem from all points of view. The berry is exceptionally large and fine flavored."

Quotation from horticulturists who inspected this berry in its home in New Jersey is as follows: "It was the most astonishing sight I have ever seen. Hedges were six feet apart, canes stood four to six feet high, and some two and one-half feet across the top and was such a mass of green, red and black berries as to almost exclude the foliage from sight. The ripe ones were big, glossy black fellows, fully onehalf larger than the Snyder. Rich. sweet and tender and melting with no hard core in center. One-third of an acre in 1902 yielded forty-seven bushels and about sixty bushels in 1903, or an average of 160 bushels per acre which sold at ten cents per quart, wholesale in the low priced New Jersey markets. This made $\$ 544.00$ per acre."
Snyder-Canes very hardy, fruit medium, round, large seeds; esteemed because of hardiness; very prolific in some parts of the west, but not satisfactory in others. Two weeks after Early Harvest.

Mercereau-Hardy and thrifty canes. Bears profusely. Large, sweet berry, similar to the Ward. Berries large, uniform in shape and size, with no core. This is a new variety which is one of the finest late berries we have ever tried in the West. We recommend it to all. July first.

Kittatinny-Large, rank growing canes, long thorns; fruit of the largest size, fine flavor; is bothered some with rust, one of the best late Blackberries rery productive. One month after Early Harvest.

Lucretia Dewberry-Very large open grained Dewberry; sweet and rich; becoming more popular every year; vine trails on ground or can be very successfully handled on low trellis.

Austin-Originated in Texas, not equal to Lucretia for northern states, but highly recommended for southern Oklahoma.

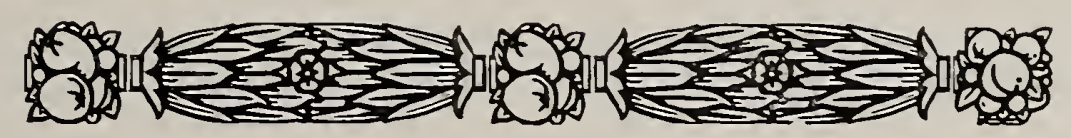

\section{RA SPBERRIES}

Ordinary raspberries were thought to be a failure in the West, but now we grow varieties that are perfectly at home in the southwestern climate and are giving fine satisfaction.

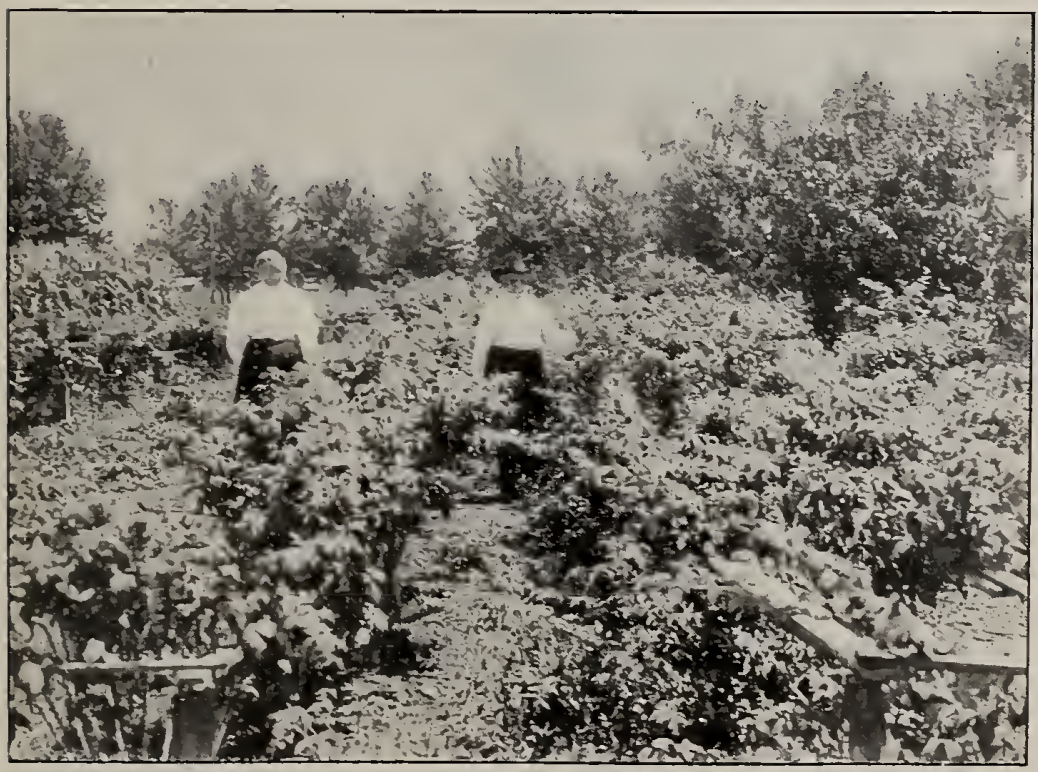
Mr. and Mrs. G. F. Kleinsteiber, Originator and Protector
of Winfield Raspberry Showing First Patch of Winfield.

Winfield--Our new Blackcap, earlier than earliest Blackcap. Wonderfully hardy, originated in this place. Recognized as best Blackcap by U. S. Pomologist. Samples for testing will be given free to regular customers for other stock who will test and report as far as supply will justify.

\section{UNITED STATES DEPARTIENT OF AGRICUL- TURE}

BUREAU OF PLANT INDUSTRY

POMOLOGICAL COLLECTIONS

Washington, D. C.. June'12. 190 s

The Winfield Nursery Co

Winfield, Kansas.

Gentlemen:-

$\mathrm{I}$ am in receipt of your faror of the Sth instant, and the box containing specimens of your new raspberry. From all appearances, this is a remarkably productive berry. Although most of the fruit was fermented we were able to get the taste of it, and we find it fully equal to the blackcap varieties. $\mathrm{O} \mathrm{n} \mathrm{e}$ peculiarity farorable to it is the small size of the seeds. Te are

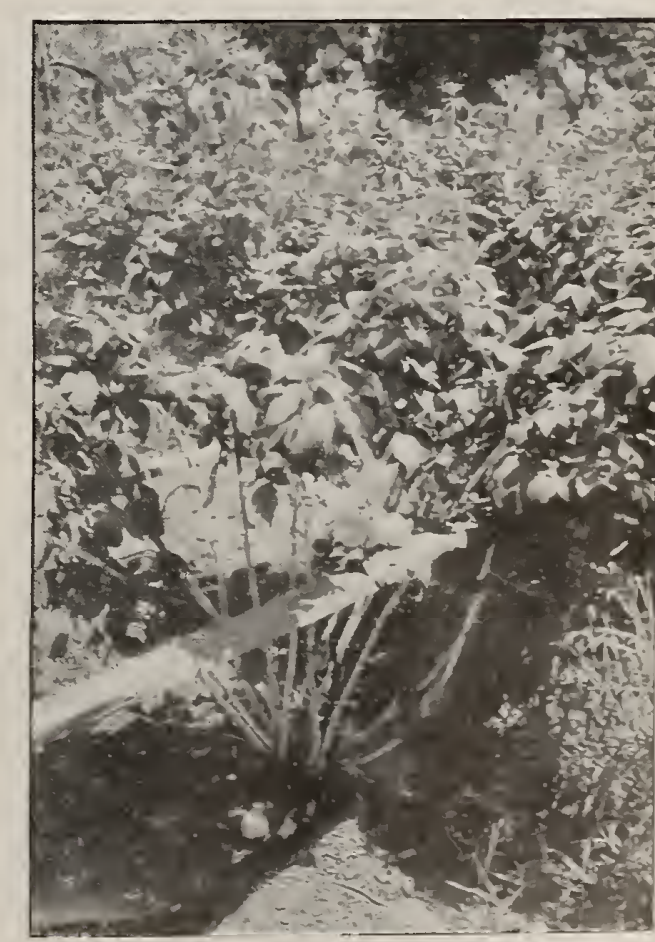

Individual Bush of Winfield Second Year, Showing Hardy Canes, Absolutely Clear of Anthracnose 
having a description and painting made of one of the best clusters for placing on file in our office. If what you say of this new variety is true you have certainly a very fine blackcap raspberry.

Thanking you for calling my attention to this new variety, and hoping to hear from you whenever I can be of service, I am,

$$
\begin{aligned}
& \text { Yours very truly, } \\
& \text { G. B. BRACKETT, } \\
& \text { Pomologist. }
\end{aligned}
$$

\section{Statement of Originator, G. F. Kleinsteiber}

"Winfield Raspberry is a chance seedling. One plant of it sprang up in 1902 about four feet from my back door. I would have mowed the plant down as a nuisance, and started to do so a number of times, but was prevented by Mrs. Kleinsteiber, as she said the plant seemed unusually thrifty and promising. The second year, 1903, I grew nine more plants from this original plant. In 1904 from these nine plants, I picked two crates and six boxes of fruit. I have gathered a heavy crop from our Winfield variety every year since, except the year 1907, in which fives crates were taken from my patch of Winfield $80 \times 33$ feet, though in that year all other raspberries in this locality failed, being killed by the late spring frosts.

The Winfield ripens about ten days before the Kansas. My first picking was on June 3rd. Single berries measured $2 \frac{1}{2}$ inches in circumference. The young plants are easy to care for and they do not lie on the ground like the Kansas; they are upright and stocky as a blackberry bush. My two year old plants now show a hedge row four feet high and five feet wide; one year old plants a hedge row three feet high and four feet wide."

\section{G. F. KLEINSTEIBER.}

Mrs. Kleinsteiber is entitled to equal honor with her husband, since a number of times he wished to dig out the chance seedling before it fruited, but it was such a promising plant that Mrs. Kleinsteiber always protested, and through her protection the world is given this valuable new Raspberry.

\section{NOTICE}

The Winfield Nursery Co. has been given sole right as introducers of this valuable new raspberry.

THE WINFIELD NURSERY CO.

Kansas--The best Blackcap. Originated at Leavenworth, Kansas; canes hardy; bore heavily with us after twenty-two degrees below zero. A perfect success in the West. Season early.

Cumberland--The best Blackcap introduced. A wonderful success in western culture. Plants grown side by side with the Kansas more than twice as large and stand strong, sturdy and upright. Berries in size resemble blackberries, in fact they are simply enormous for raspberries and far surpass any other raspberries; berries run from seven-eighths to fifteen sixteenths of an inch in diameter; perfectly firm and well adapted for long shipments. Too much cannot be said of this valuable raspberry for western planting. The Cumberland Raspberry is almost a full crop this spring while the Kansas growing by their side were almost killed by frost. Season early.

Cardinal--The first Red Raspberry we have ever recommended for this locality. Canes hardy, bearing great crops of rich, red berries; a natural western plant; originated at Lawrence, Kansas.

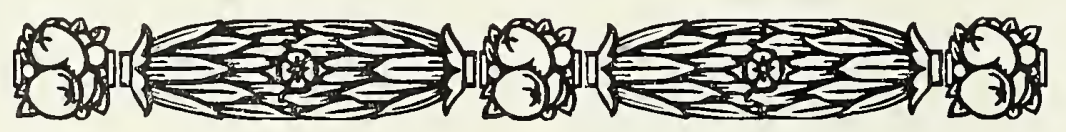

Some of the most prolific varieties (marked P) have imperfect or pistillate blossoms and will bear no fruit unless every third row is planted with varieties (marked S) of staminate or perfect plossoms.

Bederwood (S) - The standard early berry; good color; succeeds over a wide range; very prolific. Ripens one week before Crescent.

Senator Dunlap (S)-Wonderfully productive. Best and most profitable variety in this section. Plants exceptionally hardy and should be thinned on account of rapid growth. Very large, regular form; bright red; firm, very rich; stands first for canning. Season early.

Warfield (P)-Dark red; conical shape; noted for rich, fine flavor, brings extra price for table use. Very productive; fine market variety.

Capt. Jack (S)-Berries large; an old stand-by for home use and market. Plant one or a million; very productive. Mid-season.
Crescent (P)-An old standard variety; highly prized because of its hardiness and productiveness; stands drouth and neglect best of all; berries bright red; fair sized and good flavor. Fertilize with Capt. Jack or Bederwood. Season early.

Glen Mary (S)--Very large, deep red; irregular, wedge shape; flesh firm, light red, and good quality. Season first after Crescent. One of the most prolific of all the Strawberry family. Plants thrifty and hardy.

Parker Earl (S) --This grand variety is a wonder in productiveness; matured over one quart of fruit to the plant; berries long necked; bright color. Fine for market.

Gandy (S)--Very large, pointed; dark crimson, Stands at the head of late berries; firm, rich; can be shipped further than any other variety; hardy, regular and very productive.

(Note-Our special system of packing plants insures success.) 


\section{GOOSEBERRIES}

Houghton--The old standard variety; bush drooping; hardy and prolific; fruit medium size. None hardier or more prolific.

Downing-Later than the Houghton, roundish; light green, juicy, fine quality; bush more upright than Houghton.

Industry - Very large English Gooseberry. Complete failure.
Pearl-The finest berry we have ever tasted; very large, round, juicy, extra quality. Small two year bushes of this grand new variety, tried here, were covered with berries, which measured one inch in diameter.

Oregon Champion-In quality resembling Pcarl. Berries in size larger than Houghton and Downing. Small seed, bears prolific in this locality. We consider it a very valuable acquisition to the gooseberry family.

\section{CURRANTS}

The Red Currant is not well adapted to this climate.

Crandall-Very large Black Currant, originated by A. Crandall, of Newton, Kansas; bears young, regularly and very abundantly; needs no protection; fruit sweet, huckleberry flavor, very juicy. Ripens early.
Fay's Frolic--Large clusters, and one of the finest of red currents.

Red Dutch--The old standard variety of Red Currants. Well known.

Pomona-A new red currant, thoroughly tested, very prolific, superior quality and best of all red 'currants. Recommended in all localities where red currants succeed.

\section{MISCELLANEOUS}

Downing Everbearing Mulberry-Beautiful roundheaded, vigorous tree; very productive; continues for long time, with fruit in all stages, from blossoms to ripe fruit, at the same time; fruit one to one and onehalf inches long; bluish black, rich, sprightly flavor. Much finer than the old timber Mulberry.

Bismark Apple-Budded on dwarf stock, bears second and third year, and fruits well on high upland where other apples are a failure. A small dwarf tree.
Huckleberry (Dwarf Juneberry)-Bushes from four to six feet high, perfectly hardy; stands drouth and heat; fruit juicy, mild subacid.

Rhubarb-Linneaus has very large stalks; early, tender, hardy and best of all for this climate.

Asparagus--Very fine for early table use. We handle two year crown plants, which will throw up sprouts for use the first year.

\section{NUT TREES}

Great improvement of late years in nut trees. Fancy varieties of Pecans miake planters big revenue and come into bearing much earlier than seedlings. Succeed in cotton belts or latitudes south of Winfield. Some hardier varieties north of this location.

\section{PECANS}

Pabst-Very large, soft she11, fine quality, suited to extreme southern localities.

Columbian-An exceptionally large variety, tree hardy, not reconmended except for light planing on account of shy bearing.

Stuart--One of the very best commercial varieties, large, medium thin shell, quality good, tree hardy, prolific, and one of the earliest bearers.
Money-Maker-Very fine quality, good size; one of the best budded varieties. Especially hardy in northern climates. Recommended for all sections in extreme north where pecan planting is anticipated.

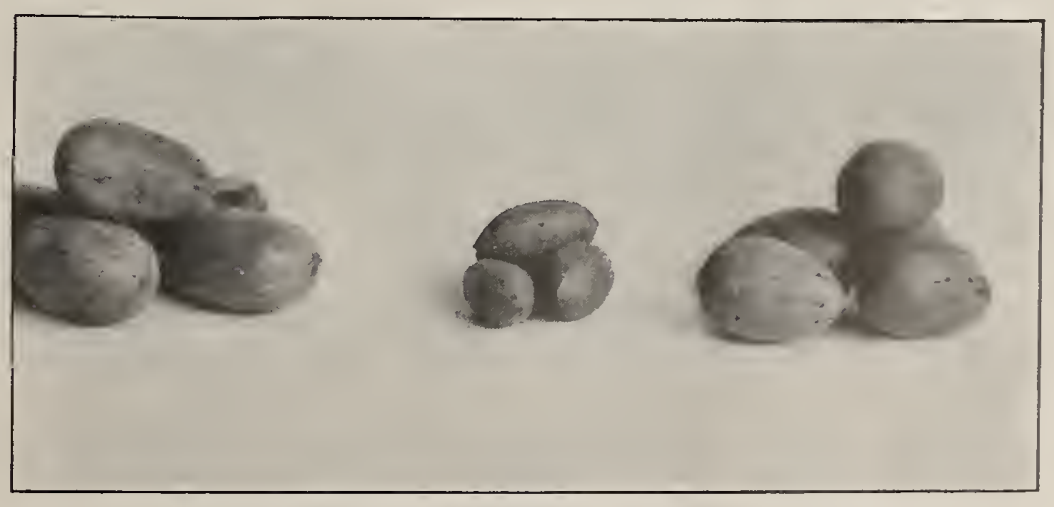

Pecan Cut Showing Columbian on the Left, Common Seedling in the Center and Money-Maker on the Right 
Pecan Seedlings--Hardy seedlings grown from select nuts. Grow wild in this locality; perfectly hardy. Will grow on wet overflow land and make valuable timber in addition to nuts. Much slower bearing than budded varieties.

Almonds (SofT SHell) - Grow successfully in this latitude, and western irrigation districts; not recommended for extreme northern planting.

Chestnut (American Sweet)-Very hardy, a beautiful lawn tree; nuts are sweet, brittle and very desirable.
English Walnuts-Succeed only in warm, southern climates, being easily winter killed.

Chestnut (JAPAN)--Being introduced quite extensively. Nuts larger than American; some varieties recommended to be as sweeet as American.

Black Walnut-Grown from seed. Is a beautiful tree, timber very valuable. Nuts are well known.

Japan Walnut--A beautiful tree in the south, large, spreading top. Nut has a small, thick shell and is of poor quality. Should not be planted for the nuts. Does not succeed in northern latitudes.

\section{SHADE AND ORNAMENTAL TREES}

Our system of growing shade trees insures smooth, well rooted, symmetrical trees. Seedlings are transplanted at one year, then after growing another year, are cut back to ground and one thrifty sprout forced into straight, smooth trunk to proper height for heading.

Maple (Soft or Silver)--Tree upright and symmetrical, foliage dense, beautiful green color; transplants easily, grows rapidly, free from worms and insects. Perfectly hardy where other maple will not succeed. We grow these in lots of one hundred thousand and recommend as one of the best for street, grove and park planting.

Elm (AMERICAN White)---Large, spreading, round top; hardy, very desirable for street and park planting. Perhaps stands at head of list.

Catalpa Speciosa--Very Large, hardy, rapidlygrowing tree; often attains a height of over one hundred feet. Large bunches of fragrant blossoms. For further particulars see Speciosa Catalpa under "Forestry and Timber Culture."

Box Elder--Rapid growth, dense, light-green foliage, round top; hardy.

Poplar (CArolina)-Hardiest of Poplar family, especially prized in western irrigation belts beecause of its hardiness and rapid growth. Tall, symmetrical, with round, spreading top; a beautiful, stately tree, recommended for high altitudes.

Ash (American White)-The old, well-known variety of Ash, hardy and used in park work for a variety of shade.

Black Locust-Very hardy, tall, symmetrical, extensively used for street shades and park work, where other varieties will not succeed. This noble tree enables many cities and towns in dry, western belts to enjoy shade, where other trees could not be grown. We grow it in large blocks and give special prices for car-load lots for city and Park work.

Maple (NoRwAy)--Round, spreading top, denser foliage than soft maple, but slower growth; in appearance more nearly resembling the Sugar Maple. Succeeds best in natural timber belts.

Maple (Sugar or HARD)-Upright, round top, more dense than soft maple; foliage turns to yellow and bright red in autumn. Not a natural tree for western planting, slow growth, succeeds with care.

Weeping Willow (KILMARNOCK)--Grafted on sixfoot stems, forms a beautiful ornamental tree with foliage reaching to the ground. Not hardy without plenty of water.

Weeping Willow (Wisconsin)-Old, well-known Weeping Willow; often reaches 50 to 100 feet in height. Very beautiful.

Birch (European White)--Large, stately tree, with silver-covered bark and foliage.

Birch (Cut-Leaf Weeping)-Fine cut foliage, upright, one of the most popular of weeping trees.

Mountain Ash--Small tree, round head, effective on account of its being loaded with bunches of bright red berries from July until winter.

Bungeii Catalpa--A perfect umbrella tree, with large, dense, heart-shaped foliage, the umbrella top being grafted on a standard tree stock. The hardiest and most beautiful lawn tree introduced in the west.

Teas Weeping Mulberry-The hardiest weeping tree known; endures both heat and drouth. 


\section{FORESTRY AND}

\section{THE FUTURE TIMBER SUPPLY}

No more vital question is before the American people. The fact that the foremost men realize this question was shown by the action taken by President Roosevelt, who convened forty-four governors and other leading men from all parts of the United States to "consider means for the saving and use of the great natural resources of our country." In addressing this meeting on the conservation of the natural resources of our country President Roosevelt believes, "It is the most weighty question now before the people of the United States." He further states: "We began with an unapproachable heritage of forests and now more than one-half the timber is gone.

President Taft recently issued a special message on conservation of our natural resources. When you look further into the question, it is plainly seen that timber must be planted at once in large blocks and even then our nation will face a timber famine for a period of at least twenty years before we can regain a position wherein the timber increase will meet the demand.

"The lavish manner in which the United States has consumed this product of its forests and the rapidity with which our timber supply is melting away are wholly unappreciated by those who have never given the matter more than passing consideration.

"No less striking than the increase in output has

been the shifting of the sources of supply, as one region has been cut out another invaded.

"The Northeastern states reached their relative maximum in 1870, and the Lake states in 1890 . The Southern States are undoubtedly near their maximum today, with about thirty-five per cent of the total lumber product, and the time of ascendency of the Pacific states is rapidly approaching. Since the census of 1900 the product of the Pacific states has risen from less than ten per cent of the lumber output of the country to twenty per cent. There will be no more shifting after the Pacific states take first place, since there is no new region of virgin timber to turn to.

"The great demand made on the forests naturally leads to the question: How much timber is now standing in the United States and how long will it last at the present rate of cutting?

"No one who is at all familiar with the situation doubts for an instant that we are rapidly using up our forest capital. In fact it is unquestionably safe to say that our present annual consumption of wood in all forms is from three to four times as great as the an-

\section{TIMBER SUPPLY}

nual increment of our forests.-Forest Service Circular No. 97.

When you further consider that white pine has increased in value from $\$ 45$. per $M$ in 1892 to $\$ 85$. per MI in 1906 , and hemlock from $\$ 13$. per $M$ in 1887 with no demand, to $\$ 22.25$ in 1907 with a great increase in demand, again you will realize the fearful speed at which we are traveling to an utter exhaustion of our timber supply.

Planters who realize these conditions first and plant at once will reap the greatest gain. The Genuine Speciosa Catalpa is rapidly proving to be the solution of "The Future Timber Supply." 
work and furniture veneer. In short, this wonderful tree alone solves the problem of The Future Timber Supply of the United States.

Bignonioides Catalpa-This is the common or scrub catalpa growing indigenous in this locality. Trees twenty years old are low and scrubby and measure five or six inches in diameter

Caution. Our customers now have posts from seedlings bought from us three years ago. Groves of the worthless common Catalpa have been growing for twenty-five years and are not so high. The great

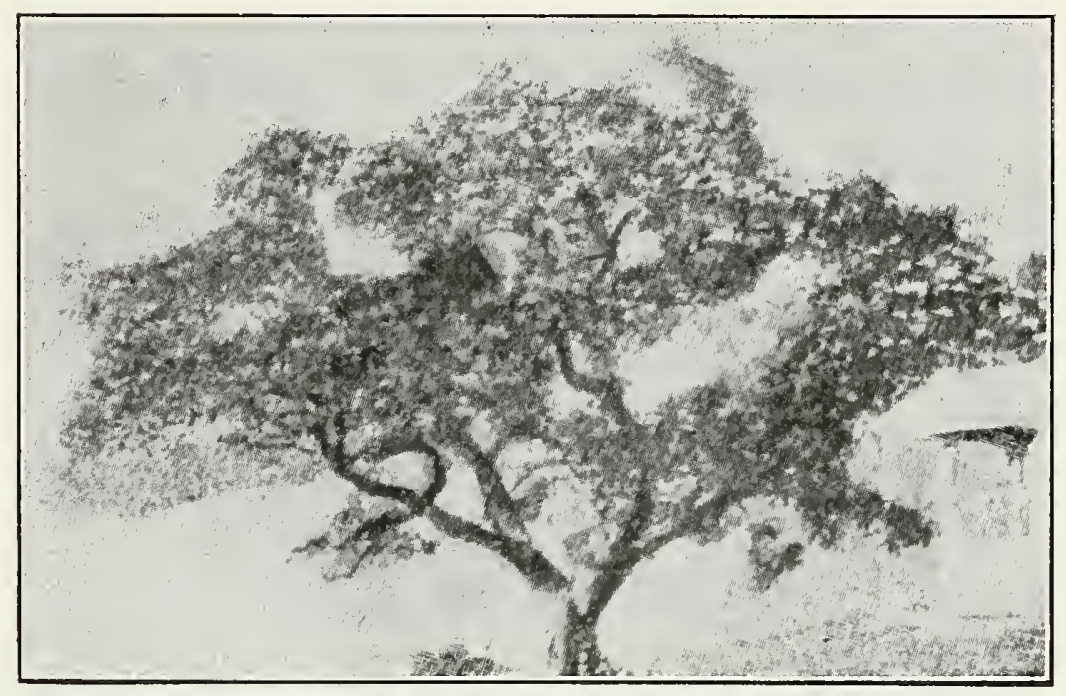

BIGNONIOIDES CATALPA profit to customers planting The Winfield Nursery Speciosa Catalpa has led many other nurseries to plant catalpa and advertise Speciosa Catalpa for sale. Many of them are honest in their intentions, and bought seed which were sold to them as Speciosa. It took us years to procure sufficient seed to grow these in large quantities. These seed now cost us five times the price of seed advertised as Speciosa. Every year seed are submitted to us as Speciosa that we must refuse. Speciosa, if grown close to common varieties will hybridize. These hybrid seed are worthless, but fool many. Genuine seed cannot be procured from seed houses. Because of our favorable location and large growing in this line, others cannot complete with us in price for Genuine Speciosa Catalpa. We caution all buyers, because a grove of any Catalpa, except the genuine Speciosa, will prove a failure. The Speciosa Catalpa will pay a profit quick and be a continual source of big revenue.

\section{ILLUSTRATED BOOKLET ON SPECIOSA CATALPA --FREE}

\section{FOREST TREE SEEDLINGS}

While we grow Speciosa Catalpa by the millions from seed gathered in Wabash valleys and passed upon by U. S. Dendrologist, we also grow Black Locust, Honey Locust, Osage Hedge, Box Elder, Ash, Russian Mulberry and Maple.

\section{EVERGREENS}

Pyramidalis--Species of Arbor Vitæ; upright grower, foliage thick with an appearance of having been pressed; beautiful and hardy.

Norway Spruce-Symmetrical grower, foliage short. spine half inch long; retains its color in winter. Rather hard to grow.
Austrian or Black Pine-Large, robust tree; foliage a dark glossy green, spine form three inches long. Our best and hardiest pine for the west.

Red Cedar-Well known, perfectly hardy and a vigorous grower.

\section{ORNAMENTAL SHRUBS AND CLIMBERS}

Japan Quince-Thorny bush, earliest in spring, with crimson flowers.

Syringa (Mock Orange)-Symmetrical bush, six to ten feet, very profuse bloomer; blossoms white, yellow center, filling a yard with their sweet fragrance. June.

Hydrangea (Paniculata Grandiflora)-Large bunches of pure white blossoms one foot in length. A fine shrub.

Weigela Rosea-Vigorous bush, covered with beautiful rose-colored flowers in June. Beautiful, rare and rich.

White Lilac--Similar to the purple but more rare. Not so well known in the west, but should be in every collection.
Weigela Candida--Resembling above, except flowers are white.

Lilac-Symmetrical bush, six to ten feet, with beautiful dark colored, heart-shaped foliage. Very profuse bloomer, fragrant. Flowers in clusters of purple.

Persian Lilac---Similar to the old favorite Lilac' except it is noted for early blooming qualities. Blooms very profusely the second year after planting. Foliage lancelet in shape, light green. Clusters of flowers very fragrant, but not so compact and beautiful as the old favorite variety.

Snowball--The old favorite Snowball produces in abundance, pure white, globular flowers in June. It s well known by everyone. 
Japan Snowball (VIbURnum Plicatum) --Very similar to the old fashioned Snowball, except a more profuse bloomer. A great success in western culture. Bushes are weighed down with beautiful clusters the second year after planting.

Althea (Rose of Sharon)--Improved double varieties of purple, red and white. Small trees, bloom in August and September, when other flowcrs are scarce.

Smoke Tree or Purple Fringe-A hardy tree shrub with a fcathery blossom, resembling curls of smoke.

Honeysuckle---White, sweet scented, changing to yellow, and the old fashioned red.
Wisteria-Hardy climbing vine, with large, pale blue bunches of blossoms.

Clematis Jackmannii--Large, deep, purple blossoms, two or three inches in diameter.

Clematis Paniculata (Sweet-scented Japan Clematis) - Of very rapid growth quickly covering trellises and arbors with handsome clean glossy foliage. The flowers are of medium size, fragrant, pure white, borne in immense sheets in September, when very few other vines are in bloom.

Privet--Small plants, of best varieties, for lawn border or hedge; vigorous, forming beautiful and almost evergreen hedge the first year.

\section{ROSES}

The Tea Roses are beautiful, delicate, everblooming roses, but are not hardy for out-door planting, though they can be grown by laying the bush down and covering with dirt in the winter.

The Hybrid Perpetuals and Climbers are very hardy for out-door planting, and our list of large, rich colors. of profuse bloomers are very fine. These we recommend for general planting.

\section{HARDY ROSES}

La France-A hardy Hybrid Tea Rose; delicate silvery pink, large, double, with an extra pleasing, attractive form, fragrant; blooming constantly from early until late.

Meteor-A hardy Hybrid Tea; very rich, dark crimson red; one of our greatest ever bloomers.

Duke of Wellington--Bright velvet red, beautiful rich red of fine form.

Gen. Washington-A large double, red rose. Bush thrifty and hardy.

Mrs. J. H. Lang-A bright pink, very fragrant; blooms the entire summer. One of the best.

Magna Charta-Grown on our grounds for the past six years, surpasses all other roses for growth, rose a bright red, large, double.

Ulrich Bruner-This rose is fragrant, growing on long stems with a rich foliage and somewhat resembles American Beauty. It is one of the promising everblooming red roses and blooms every month in the summer.

Mad. Plantier-An old summer variety, blooming in June; flower double, pure white; very hardy and suitable for a cemetery rose. red.

Duke of Edinburg-An old standard, hardy, dark

Paul Neyron-Hardy plants. The largest rose in cultivation; deep pink, blooms in June and fall.
Coquette Des Alps--Largest flowers of everblooming white roses, pure white, sometimes tinted with pale red.

Gen. Jacqueminot-One of our great favorites; scarlet crimson, large, especially showy, fragrant. Blooms in early summer and fall.

Dinsmore-Dwarfy bush, large, double scarlet crimson, fragrant, blooms freely and constantly.

Mad. Chas. Wood-A bright red, ever-blooming, hardy and highly recommended.

\section{HARDY CLIMBERS}

Seven Sisters-Blooming in clusters, red when first in bloom, changing to pink; usually showing two colors at once.

Prairie Queen-A very hardy, beautiful climbing rose, deep pink; blooms in summer.

Mary Washington--A small white rosc, half climbing, blooms profusely the entire summer.

Empress of China--A medium size pink; profuse ever-blooming climbing rose.

Baltimore Bell--White climbing rose with pale blush.

Crimson Rambler--This new Japan rose is the greatest acquisition and novelty among roses; one year bush produced seventy-five blossoms. Climbing rose of very rapid growth, small light green leaf, flowers one inch in diameter; crimson red, produced in large clusters, often so profuse that the whole vine seems one bright red banner, trimmed with green leaves.

White Rambler-Climbing rose; small, double, white, produced in clusters like crimson.

Yellow Rambler-This very hardy rose is a rapid climbing vine, light yellow. Beautiful in selection with the other ramblers. 


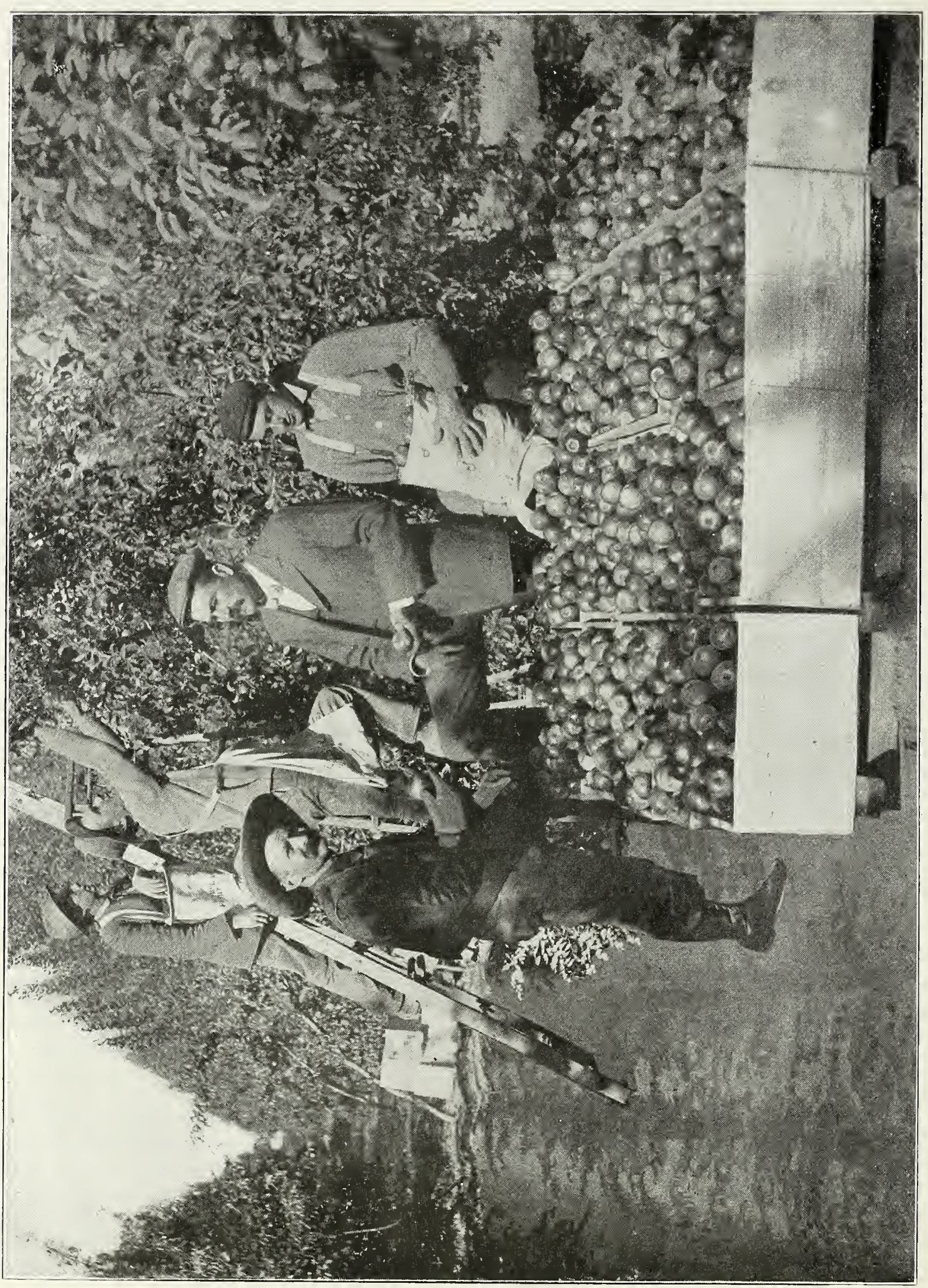

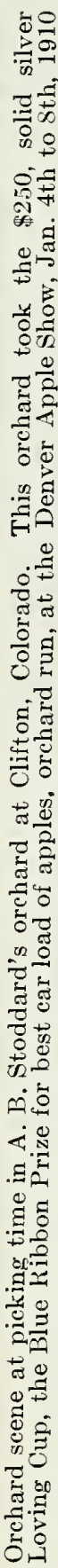




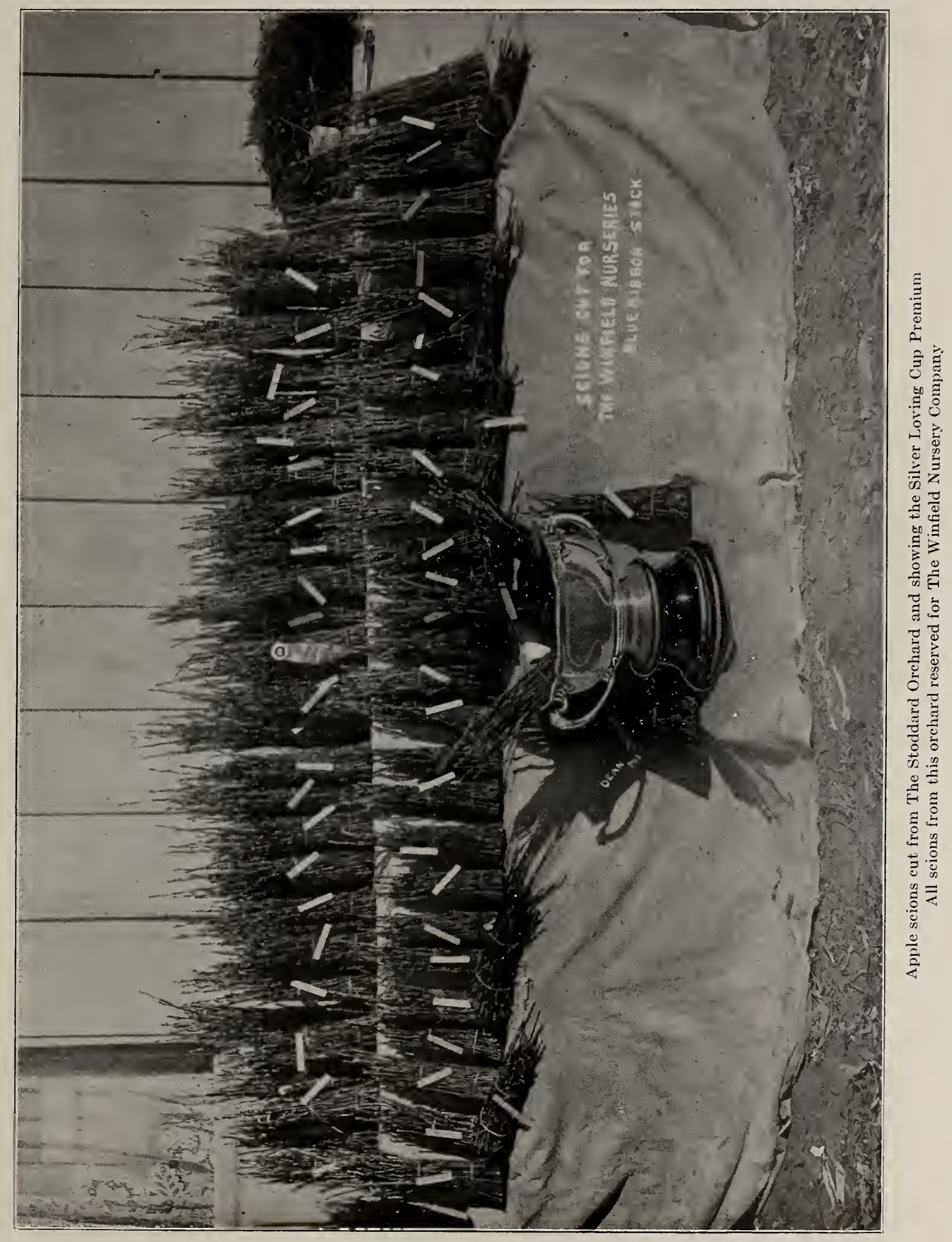




\section{NUMBER OF TREES OR PLANTS PER ACRE}

There are 43,560 square fect in an acre; divide the number by the product of the distance you wish to plant each way and it will give the number of trees or plants required to plant an acre. Thus: Peach, $15 \times 20$ equals 300 , divide 43,560 by that number and it equals 145 trees per acre. The same rule applies to all trees and plants.

\section{CARE OF TREES}

As in everything, success in orchard growing depends largely on intelligent, careful attention. We will be pleased to send our guide on the subject, mentioned above, to our friends and customers. 
